\title{
A People Apart:
}

New Brunswick Acadians, Conscription, and the Second World War by

Nancy Carvell

A thesis submitted to the Faculty of Graduate and Postdoctoral Affairs in partial fulfillment of the requirements for the degree of

\author{
Master of Arts \\ in \\ History
Carleton University
Ottawa, Ontario \\ (C) 2019 \\ Nancy Carvell
}




\begin{abstract}
During the Second World War, the Mackenzie King government faced two conscription crises, in 1942 and 1944, which divided Canadians along linguistic lines. This is the first academic history to examine the contributions of New Brunswick Acadians to the war effort, and their response to the conscription crises of 1942 and 1944. As a result of their separate identity and historical experiences, the response of Acadians in New Brunswick differed from that of other French Canadians and the anglophone majority. Acadians prided themselves on their participation and support for the war effort and opposed any attempts by anglophones to accuse them of shirking their duty. For them, opposition to conscription and support of the war effort coexisted; as a minority in an anglophone majority province, their opposition was more nuanced than that of Quebec.
\end{abstract}




\section{Acknowledgements}

First and foremost, I would like to thank my supervisor Dr. Norman Hillmer, whose confidence in my abilities far exceeds my own. Your mentorship and advice throughout every step of the research and writing process has been indispensable, and for that I am grateful.

Thank you to everyone in the Carleton History Department with whom I have had the privilege of working over the past two years; especially Dr. Candace Sobers, Dr. John Walsh, and Dr. Paul Nelles, who have tolerated my determination to do everything just a little bit differently. My work has been profoundly shaped by the discussions in your graduate seminars. I would also like to thank Dr. Erica Fraser for her mentorship throughout my two years as a teaching assistant for Europe in the $20^{\text {th }}$ Century. I must also thank Graduate Administrator Joan White for her kindness and patience in answering my every administrative question, and there were many.

Outside of Carleton, I would like to thank Christine Jack at UNB Libraries for helping me to access newspapers through document delivery. This has saved me several costly trips back to New Brunswick for additional research.

Finally, I would like to acknowledge two special friends for their support throughout this process. First, I want to thank Joël Léonard-Brouillet for always making sure I had food and listening patiently while I talked about my research. Second, I would like to thank Dr. Cindy Brown for talking me through my lowest moments. Your encouragement means more than you will ever know. 
Table of Contents

$\begin{array}{ll}\text { Abstract } & \text { ii }\end{array}$

Acknowledgements $\quad$ iii

Table of Contents $\quad$ iv

Introduction $\quad 1$

$\begin{array}{ll}\text { Chapter One: Strained Relations } & 18\end{array}$

Chapter Two: The First Conscription Crisis 47

Chapter Three: The Second Conscription Crisis 89

$\begin{array}{ll}\text { Chapter Four: Acadian Participation } & 109\end{array}$

$\begin{array}{lr}\text { Conclusion } & 129\end{array}$

$\begin{array}{ll}\text { Bibliography } & 135\end{array}$ 
Introduction

In New Brunswick, Acadians have long existed in the margins socially, politically, economically, and in the scholarship on the Second World War. By the twentieth century, their numbers had increased, and they comprised approximately 30 percent of the provincial population. The geographic centralization of New Brunswick's Acadian community along the northern and eastern edges of the province, and its low levels of assimilation, make it possible to discern their perspectives on the war, and to study the response of francophones outside of Quebec to conscription and the war effort. With only a provincial border separating them from Quebec, ideas from that province undoubtedly had some influence in Acadian communities; however, a unique set of historical experiences and a separate Acadian identity shaped their reactions. This thesis is the first academic history to examine the conscription crises of 1942 and 1944, and the Acadian war effort solely from the perspective of New Brunswick. It positions their story within the larger context of French and English Canada's responses at the national level, which have already been explored in great detail in the academic literature on manpower and conscription by prominent Canadian scholars.

The history of conscription in Canada is one of deep-seated divisions, creating fault lines between and within linguistic groups and political parties. Enforcement of the Military Service Act (MSA) in 1917 very nearly destroyed the delicate fabric of Canadian unity and saw French Canada largely isolated from the rest of the country in an election which had serious political consequences for the Conservative party in Quebec for generations to come. These memories, combined with an intimate knowledge of the hardships of war, made leaders of all political parties reluctant to adopt any policy that 
would commit Canada to overseas intervention in the late 1930s. However, a number of

Canadians believed that it was Canada's duty to support Britain. In an attempt to appease

both sides, Conservative leader R.J. Manion, followed by Prime Minister Mackenzie

King, said that Canada would stand at Britain's side but there would be no conscription

for overseas service. ${ }^{1}$

As a result of policies which promised moderate participation with an emphasis

on home defence, and rejected the use of conscription for overseas service, Canada

entered the war a united country. Initially, many Québécois were not in favour of

participation, but they acquiesced when government promises not to impose conscription

were repeated by King and his deputy, Ernest Lapointe. Lingering high levels of

unemployment as a result of the Depression ensured that there was no shortage of

volunteers for overseas service in the early years of the war. A number of the initial

enlistees throughout French and English Canada were more motivated by the prospect of

being fed, clothed, and offered a steady paycheque than by patriotism. ${ }^{2}$

The fall of France on 16 June 1940 brought Canadian complacency to a close.

Faced with pressure to adopt legislation similar to the British Emergency Powers Act and

${ }^{1}$ C.P. Stacey, Arms, Men and Governments: The War Policies of Canada 1939-1945 (Ottawa: Queen's Printer, 1970), 5-6, 397-8.

2 J.L. Granatstein, Canada's War: The Politics of the Mackenzie King Government, 1939-1945 (Toronto: Oxford University Press, 1975), 18-24; J.L. Granatstein and J.M. Hitsman, Broken Promises: A History of Conscription in Canada (Toronto: Oxford University Press, 1977), 133-5; Stacey, Arms, Men and Governments, 6; André Laurendeau, La crise de la conscription 1942 (Montréal: Éditions du jour, 1962), 25-33. In Canada's War, Granatstein writes that, even among anglophones, few were enthusiastic and most were apathetic. Public sentiment in Quebec was harder to decipher. Although many likely favoured neutrality, they recognized that ethnic and legal ties with Britain made this an impossibility. The Archbishop of Quebec, Cardinal Villeneuve, and the major francophone papers cautiously supported the government's decision while minority Quebec nationalist groups and their publications, including $L e$ Devoir and André Laurendeau's l'Action Nationale, voiced their opposition to it. Laurendeau states that the opinion of the Quebec population on the outbreak of war is impossible to know for certain. There was a state of confusion as the government and anti-participationist groups competed for support. While the antiparticipationists were vocal and did attract supporters, Laurendeau did not feel that his views were shared by the majority of his compatriots. 
to create a national government, Mackenzie King instead drafted what would become known as the National Resources Mobilization Act (NRMA), a sweeping piece of legislation which, among other things, allowed the government to conscript men solely for the defence of Canada. There was relatively little opposition to this move in the direction of conscription for overseas service, even in Quebec. Montreal Mayor Camillien Houde's denunciation of national registration saw him rapidly shipped to an internment camp, a harsh measure which caused no backlash, even from the nationalist Le Devoir that believed Houde got what he deserved. Despite a reluctance to participate in European wars, the Québécois were not opposed to taking up arms to defend their homeland. ${ }^{3}$

By 1941, quality recruits were starting to become more difficult to find, yet army planners remained confident that voluntary enlistments would be sufficient to meet the need for the foreseeable future and army expansion was allowed to continue. Japan's entry into the war on 7 December 1941 forced Canada to increase its efforts, especially with regards to home defence on the West Coast. This situation, combined with Senator and former Conservative leader Arthur Meighen's expected return to the House of Commons, led to increased calls for conscription throughout English Canada. These developments prompted Mackenzie King to reconsider his position and hold a plebiscite to ask Canadians whether they were in favour of releasing the government from its pledge not to impose conscription for overseas service. The plebiscite revealed the extent of the divisions between French and English Canadians. French Canadians, who believed that the promises had been made especially to them as a condition for their participation in the war effort, voted in overwhelming numbers against releasing the government from

\footnotetext{
${ }^{3}$ Granatstein and Hitsman, Broken Promises, 140-5.
} 
its pledge. They feared that the plebiscite was merely a stepping stone to conscription for overseas service. Many anglophone Canadians, on the other hand, believed that Canada should do whatever was necessary to win the war and support the soldiers overseas. These anglophones believed that Quebec was not doing its share for the war effort because it had provided a smaller proportion of volunteers than the other provinces.

The plebiscite results revealed that 2,945,514 Canadians had voted to release the government from its pledge, while 1,643,006 had voted against it. A closer examination reveals conscription had divided the public along racial lines. ${ }^{4}$ Anglophones had overwhelmingly voted yes, while Quebec was the only province to return a negative majority, with 72.9 percent of voters against releasing the government from its pledge. Following the plebiscite, tensions subsided until the fall of 1944 when the impending shortage of infantry reinforcements led to renewed calls for conscription. When it became clear that voluntary recruitment could not secure the required reinforcements, King reluctantly put forth a motion to send up to 16,000 conscripts overseas. Parliament passed the motion in November 1944 and the first conscripts left Canada for Britain early in 1945. Histories of the conscription crises all describe these events, focusing their examinations on the divisions between Quebec and the rest of Canada. These monographs provide a solid account of events at the national level, yet largely ignore the opinions of French-Canadian minority populations outside of Quebec, leaving this area of study to be examined by other scholars.

\footnotetext{
${ }^{4}$ Although today Anglophones and Francophones would be described as separate linguistic or cultural groups, they were often considered different races during this period. The word 'race' appears frequently in discussions on the differences between the two groups and their viewpoints, including the primary source literature on conscription. In an effort to capture the opinions and beliefs of the individuals involved, this thesis will use the word race in this historical context.
} 
One of the earliest accounts of conscription during the Second World War, R. MacGregor Dawson's The Conscription Crisis of 1944, published in 1961, explores the events leading to the agonizing decision to impose limited conscription for overseas service, largely from the point of view of Mackenzie King and General Andrew McNaughton, who had replaced J.L. Ralston as Minister of National Defence. Drawn from interviews, Cabinet documents, and the King diaries, Dawson presents the situation from the point of view of elected officials who were reluctant to send conscripts overseas. He blames the generals for the creation of the large army and for their reluctance to continue with the voluntary recruiting system, while dismissing the occurrence of an outright revolt of the army leadership. ${ }^{5}$ Dawson's work generally avoids the public's position on the issue except for a discussion of how Ralston's dismissal was instrumental in bringing French Canada to accept the necessity of conscription by demonstrating the extent to which King was prepared to go to avoid it. ${ }^{6}$

In his detailed history of Canadian policy related to conduct of the war, Arms, Men and Governments, published in 1970, C.P. Stacey dedicates an entire chapter to exploring the problems and policies surrounding manpower and conscription. Although he attempts to explore these issues from a "military rather than political point of view,"” Stacey's use of government documents, national newspapers, and the papers of generals and politicians, including Mackenzie King, results in an analysis that focuses on the actions of King, his Cabinet colleagues, and the army leadership. Unlike Dawson, Stacey concludes that "the government's military advisers had exercised their constitutional

\footnotetext{
${ }^{5}$ R. MacGregor Dawson, The Conscription Crisis of 1944 (Toronto: University of Toronto Press, 1961), 94-97.

${ }^{6}$ Dawson, Conscription Crisis, 123-5.

${ }^{7}$ Stacey, Arms, Men and Governments, 397.
} 
function with complete propriety." ${ }^{, 8}$ With its emphasis on national events, however, his account of conscription does not acknowledge variations in opinion on the conscription question within provinces, making it seem as if French Canada stood uniformly alone in its opposition to conscription while English Canada supported it. ${ }^{9}$

J.L. Granatstein relies on similar sources in Canada's War, in which he explores how King and his government dealt with various aspects of the war effort. Granatstein characterizes this work as a study in the way nationalism developed in Canada throughout the Second World War. He credits King's balancing act during the debates on conscription with ensuring that divisions between conscriptionists and anticonscriptionists did not reach the point of fracturing Canadian unity as they had in 1917. ${ }^{10}$ The discussion of conscription and French Canadians outside of Quebec is limited to a page on the plebiscite results. Granatstein notes that "French Canadians, wherever they lived in Canada, had voted against conscription, and they had been joined to a substantial extent by non-Anglo-Saxon voters." Six of the eight constituencies outside Quebec which returned a no majority in the plebiscite were largely French Canadian, three of which were located in New Brunswick, the province with the second largest no vote. ${ }^{11}$

Granatstein and J.M. Hitsman's Broken Promises: A History of Conscription in Canada explores the use of conscription throughout Canada's history with an emphasis on the First and Second World Wars. They consider English Canada's imposition of conscription upon French Canada in 1917 and again in 1942 and 1944 to be the most

\footnotetext{
${ }^{8}$ Stacey, Arms, Men and Governments, 471.

${ }^{9}$ Stacey, Arms, Men and Governments, 400-1.

${ }^{10}$ Granatstein, Canada's War, v-vi.

${ }^{11}$ Granatstein, Canada's War, 227.
} 
divisive issue in Canadian history. On the issue of French Canadians outside Quebec, this monograph takes a similar approach to Canada's War, with only a paragraph dedicated to discussing the plebiscite results in other provinces. ${ }^{12}$

The more recent book, Daniel Byers' Zombie Army: The Canadian Army and Conscription in the Second World War, examines the army's role in the development of the compulsory military training system. The ability to call out more conscripts for home defence, he argues, was a significant factor in allowing the army leadership to push for the creation of a large army and enticing the political leadership to accept the idea. The construction and day-to-day operations of the army and the compulsory training system thus played a role in shaping the political crises surrounding conscription. Using administrative and statistical sources, Byers was able to draw a demographic portrait of the men who served as conscripts and the manner in which the army attempted to encourage them to volunteer. Byers' assessment dispels the myth that the vast majority of conscripts were francophones, demonstrating that, as a group, the conscripts were more representative of Canadian society than had previously been assumed. While Byers' sources allowed him to reconstruct the experiences of conscripts as a group, they do not permit an analysis of individual experiences nor of the experiences of smaller sub-groups within particular provinces, such as anglophones and francophones in New Brunswick. ${ }^{13}$ In light of the sizeable body of literature which details Québécois actions and attitudes during the Second World War, the literature on Acadians during the same period seems rather sparse by comparison. This is largely a result of the tendency of Canadian

\footnotetext{
${ }^{12}$ Granatstein and Hitsman, Broken Promises, 1-2, 171.

${ }^{13}$ Daniel Byers, Zombie Army: The Canadian Army and Conscription in the Second World War (Vancouver: UBC Press, 2016), 5-9, 126-33.
} 
historians to assume that the perspectives of the Québécois apply to all French Canadians. The following examination of the literature on Acadians during the Second World War is not exhaustive, but rather is intended as a sample of the major works from which this thesis is drawn and of the literature to which it contributes.

The Acadians of the Maritimes: Thematic Studies, published in 1982, contains an essay by Philippe Doucet, entitled "Politics and the Acadians." Doucet explores the history of Acadian participation in, and frequent exclusion from, politics, dating back to the early days of Acadian settlement. Doucet claims that Acadian identity stems from their often-tragic history, which continues to shape their views and responses. In a short passage on the Acadians and the Second World War, Doucet comments on the Acadian vote in the 1942 conscription plebiscite. He points out that approximately 70 percent of Acadians voted against releasing the government from its promise not to implement conscription, despite being encouraged to vote yes by their MPs and multiple advertisements in the French language press. Despite their negative vote, Doucet notes that Acadians were determined to support the war effort; however, the decision to implement conscription opened old wounds. This was not the first time that the will of the majority had been forced on the Acadians, even though a large part of the population had voiced their opposition to the proposed measures. ${ }^{14}$

In her PhD dissertation, "The Acadian Response to the Conscription Crisis of World War II," Helen Jean McClelland Nugent notes that traditional analyses of conscription assume that Québécois attitudes were shared by all francophone Canadians.

\footnotetext{
${ }^{14}$ Acadians voted overwhelmingly against the Union government and conscription in 1917, even though the measures were supported by some of the Acadian elites. The Acadians also voted overwhelmingly against Confederation in 1865 and again in 1866.
} 
Her dissertation challenges this assumption and explores conscription from the perspective of Maritime Acadians in an attempt "to measure their role in the conscription crisis ... and to assess whether or not it is legitimate to assume that their response was identical to that of Quebec." ${ }^{15}$ Nugent's analysis is based on an examination of articles from two Acadian newspapers, La Voix d'Évangéline and Le Petit Courrier, a statistical analysis of voting percentages in Acadian majority ridings, and interviews with Acadians from all three Maritime provinces. ${ }^{16}$ Nugent concludes that there were regional variations of opinion among French Canadians that were partially due to geographic location and social differences within the francophone population. She believes that Acadian bilingualism, proximity and cooperation with anglophones in day-to-day life, a closer proximity to the dangers posed by German U-boats, and higher levels of 'Canadian' identity made Acadians less opposed to conscription than the Québécois. Although Nugent notes that no Acadians wanted conscription, she concludes that this period does not represent a "critical juncture which would create a closer Francophone identification within the Acadian community as it may have done in Quebec. Instead, as the reminiscences of present-day residents show, it served to mark the Acadians as Maritimers. ${ }^{17}$ Based on the experience of conscription in all three Maritime provinces, Nugent's conclusion does not fully take into account how the experience of war and conscription differed between and within each province due to the circumstances present in each, something this thesis explores in greater detail in the context of New Brunswick.

\footnotetext{
${ }^{15}$ Helen Jean McClelland Nugent, "The Acadian Response to the Conscription Crisis of World War II" (PhD Dissertation, Michigan State University, 1983), 7.

${ }^{16}$ While she interviewed individuals from all three provinces about their memories of the conscription crisis, Nugent notes that most of the interviewees who were able, and or willing, to discuss their memories and experiences were from Nova Scotia and Prince Edward Island.

${ }^{17}$ Nugent, "The Acadian Response," 113.
} 
Some of the writing on Acadians in the Second World War is intended for a public audience, such as the work of Acadian journalist and amateur historian Ronald Cormier. Cormier published two collections of testimonials from Acadian Second World War veterans, J'ai vécu la guerre: Témoignages de soldats acadiens, 1939-1945 in 1988 and Entre bombes et barbelés: Témoignages d'aviateurs et de prisonniers de guerre acadiens, 1939-1945 in 1990. The purpose of these books was to record the veterans' experiences in their own words, and as such, there is no historical analysis or background. All of the testimonies were from volunteers who served overseas; however, some mentioned that the belief they were likely to be conscripted had encouraged them to volunteer. While many of the experiences described were not unique to Acadian servicemen, a few veterans disclosed how being francophone affected their military experience.

Cormier's third book, Les Acadiens et la Seconde Guerre mondiale, published in 1996 is the first attempt at producing a history of Acadian participation in the Second World War. He briefly discusses the experience of war on the home front, followed by a discussion of conscription, mostly centred on the plebiscite vote and utilizing information from a variety of Maritime newspapers. He explores Acadian experiences of military service, drawing heavily from his previous two books. Finally, using fragmentary unit records and casualty lists, Cormier attempts to calculate the number of Acadians who served during the war. Cormier writes that after the war some anglophones accused the Acadians of attempting to avoid enlistment and shirking their duties as citizens. He intends this book to demonstrate that "les Acadiens ont bel et bien servi le Canada au sein des forces armées même si ... le pays n'a pas toujours considéré les Acadiens comme des 
citoyens ou des soldats à part entière." ${ }^{18}$ While this is the most complete work on the Acadians in the Second World War to date, and accurately portrays events from the point of view of his sources, it is intended more for public consumption and lacks historical context and academic analysis. Available in French, Cormier's work is largely aimed at other Acadians who want to know more about their community's war effort.

Patricia D. Thibodeau's undergraduate thesis, “The Re-Emergence of an Acadian Collective Identity as Highlighted by the Conscription Crisis of 1942," is the first study to explore conscription solely from the perspective of New Brunswick Acadians. Her assessment touches briefly on conscription in the First World War and focuses on the 1942 plebiscite. She examines what she views as the emergence of an Acadian identity during the early years of the twentieth century through gradual Acadian advancements in education, economics, and politics. While the Québécois and New Brunswick Acadians voted similarly in the plebiscite, she concludes that the two groups did not share the same worldview and that the Acadian response to conscription was developed without Quebec assistance. Ultimately, Thibodeau concludes that Acadian collective identity came of age as a result of the plebiscite, which served as a turning point in the Acadians' struggle for equality with the anglophone majority. ${ }^{19}$

Conscripted men rarely spoke about their experiences, and very few authors have been able to write about them from their own perspective. Mélanie Morin-Pelletier's article “'J'ai combattu le bon combat, j'ai achevé ma course, j'ai gardé la foi' 1 Récit de guerre d'un conscript néo-brunswickois, 1943-1945," published in Canadian Military

\footnotetext{
${ }^{18}$ Ronald Cormier, Les Acadiens et la Seconde Guerre mondiale (Moncton, NB: Éditions d'Acadie, 1996), 10.

${ }^{19}$ Patricia Thibodeau, "The Re-Emergence of an Acadian Collective Identity as Highlighted by the Conscription Crisis of 1942" (Undergraduate Thesis, Mount Allison University, 1997), 31, 73.
} 
History in 2015, is one of the few which has been able to do this. Through the story of René Morin, an Acadian from Edmundston, New Brunswick, Morin-Pelletier explores Madawaska county's contributions to the war effort as well as the experiences of conscripts more generally. Although most other accounts of Acadian participation maintain that they volunteered readily for overseas service, Morin-Pelletier suggests that recruiting numbers in Madawaska indicate the men from that county were actually reluctant to enlist. No concrete reason for this could be determined, but she suggests that this reluctance may have been due to responsibilities at home, particularly for farmers, a belief that francophone soldiers were not treated as well as their anglophone comrades, and potentially because they believed non-military support for the war effort was of equal value to enlistment. ${ }^{20}$

Another article on the Acadians in the Second World War, titled 'L'Acadie et la Seconde Guerre mondiale," appeared in Acadiensis in 2016. Rather than to outline the findings of completed research, the purpose of this article, written by Julien Massicotte and Mélanie LeBlanc, is to create an outline for an interdisciplinary research project that explores the Second World War in Acadia as a comprehensive social phenomenon. As such, the article poses many questions that it is not able to answer given the current research on the subject. Massicotte and LeBlanc state that prior research has sought to produce a unifying Canadian national discourse and, consequently, has paid less attention to regional differences. Because of the specific historical circumstances in which the Acadians existed as a francophone minority dominated by the anglophone majority, they

\footnotetext{
${ }^{20}$ Mélanie Morin-Pelletier, “'J'ai combattu le bon combat, j'ai achevé ma course, j'ai gardé la foi': 1 Récit
} de guerre d'un conscrit néo-brunswickois, 1943-1945," Canadian Military History 22, no. 4 (2015): 48-50. 
experienced the war differently from other Canadians. ${ }^{21}$ Their research takes a sociolinguistic perspective and seeks to improve understanding of three aspects of the Acadians' Second World War experiences: construction of social representations, representation of the war in the discourses of elites, and popular perceptions of the war. ${ }^{22}$

The most recent work on the Acadian experience of the Second World War is Ryan d'Eon's Master's thesis, "Away but Still at Home: A History of South Shore Nova Scotian Acadians During the Second World War." While d'Eon's research focuses on the experiences of Acadians in Nova Scotia, some of their experiences are similar to those of Acadians in New Brunswick. For instance, a desire to protect Catholicism was an important factor which encouraged both groups of Acadians to participate in the war effort. Both groups were also heavily engaged in fundraising and non-military forms of volunteerism. However, differences in geography, population integration, and the historical experiences of Acadians in Nova Scotia and New Brunswick resulted in some differences in the way they experienced the war and military service. Acadians in Nova Scotia were less concerned than their New Brunswick counterparts about a lack of French-language training camps or an Acadian unit. They also reported less discrimination based on language. ${ }^{23}$

Scholars have thus examined the broader experience of the Second World War from the perspective of Acadians in all three Maritime provinces. While much more specific than the national-level narratives, the literature which approaches these issues

\footnotetext{
${ }^{21}$ Julien Massicotte et Mélanie LeBlanc, "L'Acadie et la Seconde Guerre mondiale," Acadiensis 45, no. 2 (2016): 53.

${ }^{22}$ Massicotte et LeBlanc, 65-66.

${ }^{23}$ Ryan d'Eon, "Away but Still at Home: A History of South Shore Nova Scotian Acadians During the Second World War" (MA Thesis, University of New Brunswick, 2018), 118-21.
} 
from the Maritime perspective sometimes results in inaccurate generalizations. The unique geographic situation, history, political situation, and population demographics make the New Brunswick experience of conscription and Acadian participation in the war effort somewhat different from that experienced by Acadians in Nova Scotia or Prince Edward Island.

There is a dearth of studies of conscription related topics from the perspective of New Brunswick Acadians. Very few New Brunswick Acadians, military or civilian, have left behind a record of their wartime experiences. Rarer still are oral or written testimonies of men who were conscripted, since the stigma associated with having been a conscript persisted after the war. As firsthand accounts are not forthcoming, local newspapers form the most complete and accessible source of information on the conscription crises in New Brunswick. Three New Brunswick newspapers, L'Évangéline ${ }^{24}$, Le Madawaska, and the Daily Gleaner are the main sources for this thesis. These papers were closely read for the period 1939-1945. Articles were analyzed to determine the opinions of the francophone and anglophone populations on conscription and the war effort, and how both of those groups experienced these events. The analysis was not confined to writings about conscription and the war effort. In the francophone papers especially, articles on other topics, such as religion or education, provided insight into the nature of Acadian identity and thought patterns, and how each was shaped by historical experience. It was also possible to see how the New Brunswickers' experiences, outlined in the papers, either reflected or differed from those presented in the literature on conscription. To provide a broader perspective on these events, the House of

${ }^{24}$ L'Évangéline was known as La Voix d'Évangéline between 1937 and 1944. This thesis will refer to the newspaper by the name that was in use at the time each article was written. 
Commons Debates, the Canadian Army (Basic) Training Centre (CA(B)TC) war diaries for Fredericton and Edmundston, and other archival documents, including the records of l'Ordre de Jacques-Cartier (OJC), were consulted to supplement the newspapers. ${ }^{25}$

Chapter one provides a detailed analysis of Acadian history from the earliest days of settlement until the outbreak of war in 1939. It explores the complex relations between francophone and anglophone settlers and francophone reluctance to acquiesce in the demands of the anglophone leadership once the colony was ceded to Britain for the final time. Based on the research of Naomi Griffiths and others, this chapter demonstrates that a distinctive Acadian identity had already developed prior to the First World War. This combination of identity and the experience of systemic discrimination at the hands of the anglophone majority played a vital role in forging a unique Acadian response to war and conflict. The chapter also explores the Acadian response to conscription in the First World War. While they were not opposed to the war itself and many Acadian men enlisted voluntarily, Acadians were opposed to being conscripted to fight in what they believed to be a foreign imperial war. The way conscription was enacted in the province also created lasting scars, which would continue to affect their relationship with the anglophone community and would later influence Acadian opinions and fear of conscription in the Second World War. Finally, the chapter shows how the struggle to combat discriminatory practices in the interwar years resulted in Acadians throwing off their cloak of silence and starting to speak up for the rights and needs of their community.

\footnotetext{
${ }^{25}$ L'Ordre de Jacques Cartier was a secret French-Canadian society founded in Ottawa in 1926 that sought to promote the French language and community in Canada. The first New Brunswick branch was founded in Campbellton in 1933 and additional branches soon appeared in other communities. The group pushed for reform of French language education and to increase the profile of the French language and French speakers within the province. Members were pledged to secrecy and spread their ideas by word of mouth and through action.
} 
Chapter two explores the early years of the Second World War and the first conscription crisis culminating in the plebiscite of 27 April 1942. It demonstrates that Acadians were not opposed to the war, but that they took comfort in Mackenzie King's policy of limited liability and his pledges not to impose conscription because of fears that the divisions and disunity of 1917 might once again become reality. Initially, Acadians were not opposed to the NRMA as the conscripted men were to be employed in home defence formations. They were, however, opposed to any amendments to the act which would force conscripts to serve overseas. Much of this chapter focuses on the opinions expressed by New Brunswickers in the weeks leading up to the plebiscite in Parliament and in the newspapers, and on the plebiscite results in the province. An analysis of the results demonstrates that the Acadian response to conscription was not identical to that of Quebec, but rather was a product of the Acadians' separate identity and experiences as a francophone minority in a largely anglophone province.

Chapter three begins with an examination of the aftermath of the plebiscite vote and the debate over Bill $80 .{ }^{26}$ Even though their constituents were opposed to conscription for overseas service, all three of New Brunswick's Acadian MPs voted with the government to pass Bill 80 and remove restrictions on deploying conscripts outside of Canada. After the passage of Bill 80, concerns over conscription subsided until 1944; however, conflict between anglophones and francophones continued, largely over the use of language in schools. This demonstrates that Acadian self-advocacy and resistance to the anglophone agenda were not solely linked to conscription, but were part of an ongoing process by which Acadians were exercising their rights as a minority. The final

${ }^{26}$ Introduced by King on 11 May 1942, Bill 80 was used to amend the NRMA, by removing Section 3 which prevented conscripts from being forced to serve outside Canada. 
part of this chapter explores the 1944 conscription crisis, including the pressures on the NRMA men to go active and the Acadians' reluctant acceptance of the government's decision to send conscripts overseas.

The first three chapters deal with the Acadians' experiences of the conscription crises, but this forms only part of their wartime experience. Many anglophones who sought to implement conscription were motivated not only by a belief that this was the most effective way to ensure that reinforcement needs were met but also by concerns that French Canadians were not contributing their fair share to the war effort. Acadians rejected this notion that their contributions were insufficient and were anxious to demonstrate their commitment to the war effort. Despite their desire to participate, the Canadian military was largely an anglophone institution and was unprepared to handle the influx of francophone recruits with limited knowledge of English. Chapter four explores the ways that Acadians supported the war effort, as civilians who volunteered their time and money, and in the military as volunteers or home defence conscripts, and includes a discussion of the challenges and barriers to participation faced by some New Brunswick francophones. 


\section{Chapter One}

\section{Strained Relations}

European exploration of the coasts and waters of North America began in earnest in the sixteenth century. France and England developed strong political interests in these new, sparsely populated lands rich in natural resources as potential sources of territorial expansion. Attempts at permanent settlement followed as a means to claim jurisdiction over resources and future colonial development. ${ }^{27}$ While settlers enjoyed considerable freedom in shaping events on the ground, the territory remained a pawn in European diplomatic exchanges between Britain and France, changing hands several times over the first 150 years, but ultimately coming under British control. ${ }^{28}$ In an attempt to live in peace and to avoid being drawn into the frequent wars between France and Britain, the Acadians accommodated both sides but remained a separate people. This strategy served them well for many years, but their refusal to become British subjects resulted in their expulsion in 1755. Upon their return, the Acadians found that the nature of conflict between francophones and anglophones had changed, taking on social, political, and economic forms. As a linguistic minority in what would become the Maritime provinces, Acadians found that their needs and desires were overlooked by the majority. Lacking education and influence, trapped in a cycle of poverty, the Acadian community languished for many years until it gradually began to assert itself. The Acadian community's collective experience of neutrality and accommodation, deportation, and

${ }^{27}$ John Bartlet Brebner, New England's Outpost: Acadia Before the Conquest of Canada (Hamden, CT: Archon, 1965), 17-19; Naomi E. S. Griffiths, From Migrant to Acadian: A North American Border People 1604-1755 (Montreal: McGill-Queen's University Press, 2005), 3.

${ }^{28}$ Naomi E. S. Griffiths, The Contexts of Acadian History, 1686-1784 (Montreal: McGill-Queen's University Press, 1992), 6-7. 
gradual resurgence would shape their opinions on significant issues and the way these opinions were communicated to the majority. ${ }^{29}$

The first formal attempt to settle what would become known as Acadia or Nova Scotia occurred in 1604 when the French King Henri IV granted nobleman Pierre Du Gua, Sieur de Monts, jurisdiction “au pays de la Cadie." ${ }^{30}$ In exchange for a ten-year monopoly of the fur trade, de Monts was expected to colonize the territory and convert the Indigenous inhabitants to Christianity. ${ }^{31}$ During this period, French control of Acadia was tenuous. The territory was both expansive and vaguely defined, consisting mostly of sparsely inhabited wilderness, with travel mainly limited to the waterways surrounding and traversing the territory. Harsh winters meant that few men remained in the colony year-round. The French were not the only ones with an interest in the lands south of the St. Lawrence. The English, who had established themselves in Newfoundland and along the eastern seaboard of the United States, also sought to increase their claims to North America. $^{32}$

The French did not relinquish their claims to Acadia despite competing counterclaims, raids, and attempts at settlement. Nor did the French settlers, fishermen, and fur traders abandon the territory as a result of the English incursions. If one

${ }^{29}$ Early Acadian settlements were located, in what are now the separate provinces of New Brunswick and Nova Scotia, but which, until 1784, formed one colony, Acadia under the French, and Nova Scotia under the British. As such, the first part of this chapter will also examine events which took place in what is now the province of Nova Scotia.

${ }^{30}$ Griffiths, From Migrant to Acadian, 4. The territory extending from the $40^{\text {th }}$ to the $60^{\text {th }}$ parallel or approximately from present day Philadelphia to Cape Breton, including present day Nova Scotia and New Brunswick.

${ }^{31}$ Ronald Rees, New Brunswick: An Illustrated History (Halifax, NS: Nimbus, 2014), 10.

${ }^{32}$ Brebner, New England's Outpost, 20-21; Griffiths, From Migrant to Acadian, 23-25. In 1621, eighteen years after the first land grants made by the French monarch, King James I of England (James VI of Scotland) granted rights to Sir William Alexander for virtually the same piece of land which he called Nova Scotia (New Scotland). 
settlement was destroyed or captured, the survivors merely moved their base of operations to an area further from English influence while pleading for aid from France. Largely as a result of geographic ignorance and a lack of interest, the French crown was of little assistance. For instance, Acadia ended up with two governors when Charles de La Tour was appointed on 8 February 1631, and Isaac de Razilly, on 10 May 1632, without La Tour's appointment being redacted. Despite this mismanagement, Razilly's settlement became an agricultural success and he was credited with bringing between one and two hundred permanent settlers to the colony, including a number of women and children. This group of settlers along with smaller numbers of later arrivals would become the ancestors of the Acadian people. ${ }^{33}$

Acadia came under English control in 1654. From 1654 to 1670, the colony was administered by Thomas Temple from New England. ${ }^{34}$ These years of English control were relatively uneventful for the Acadian settlers. There were no attempts to turn them into English subjects nor was there a large influx of Anglo-Protestant settlers. The Acadians had more contact with the English than the French during this period and came to view coexistence with the English as a normal part of daily life. These events would have an important impact on shaping the Acadian character and worldview, including the development of "a spirit of accommodation with English authorities," 35 a view that would influence their later behaviour with regard to the English authority.

\footnotetext{
${ }^{33}$ Brebner, New England's Outpost, 28-29; Griffiths, From Migrant to Acadian, 48-52. The first surviving record of a ship sailing to Acadia with women and children on board was the Saint Jehan which left La Rochelle 1 April 1636. While some historians believe these were not the first European women to come to Acadia, there is no earlier record either of their sailing nor their presence after arrival.

${ }^{34}$ Brebner, New England's Outpost, 31-33; Raymond Blake et al., Conflict \& Compromise PreConfederation Canada (Toronto: University of Toronto Press, 2017), 46-48.

${ }^{35}$ Jean Daigle, "Acadia, 1604-1763 An Historical Synthesis," in The Acadians of the Maritimes: Thematic Studies (Moncton, NB: Centre d'études acadiennes, 1982), 23. Acadian settlers were permitted to remain on their lands, and the Catholic priests with them. Acadian fur traders, fishermen, and settlers readily
} 
Acadia was restored to France in 1670 . Accompanied by a number of settlers and soldiers, the new governor, Grandfontaine, was not only responsible for restoring French authority and regulations among the Acadians, who had become accustomed to living independently during the period of English control, but also for preventing what had become frequent incursions by New England traders and fishermen. Governor Grandfontaine and his successors failed to achieve either objective. Historians agree that this was largely a result of a shift in Acadia's "place in the political geography of North America ... [to that of] a border colony between two great empires." ${ }^{36}$ Despite its strategic position, the Acadian governors continued to receive as little attention and resources from the French government as it had under previous administrators. French control of Acadian territory from 1670 to 1710 was marginal at best. Daigle refers to Acadia as the weakest colony in North America at this time, both in terms of population and resources. ${ }^{37}$

In times of armed conflict between the English and French during this period, Acadia frequently became a battleground due to its geographic location. Such was the case in 1690, when Port Royal came under siege in revenge for attacks against the New England colonies by the French and their First Nations allies. Outnumbered three to one, Port Royal surrendered. A number of men from among the Acadian population were selected and named members of the "Council for the conservation of peace" and made to swear an oath of loyalty to the English crown. Not intending to occupy the settlement, the

diverted their trade goods to New England, but this was simply a matter of trade, not loyalty. Having witnessed the frequent changes in administration, Acadians were gradually becoming indifferent to outside authority.

${ }^{36}$ Griffiths, From Migrant to Acadian, 81.

${ }^{37}$ Brebner, New England's Outpost, 43-45; Daigle, “Acadia, 1604-1763," 24-30. As late as 1710, Daigle estimates the population of peninsular Nova Scotia to be only 1,700 while the population of the New England colonies was around 357,000. 
pillaging force withdrew to Boston, leaving the Acadian council members in charge of local affairs. ${ }^{38}$ Such events reinforced the Acadians' attitude of accommodation, which they applied indiscriminately to both the French and the English. This accommodation of the stronger combatant was, according to Daigle, "the Acadians' way of obtaining a little security and ensuring that they would not be evicted from their farms and villages." 39

In 1710, Acadia changed hands for the last time when a force of one thousand New Englanders and British troops captured Port Royal. This time the British intended to stay and left behind a force of four hundred soldiers in the colony to maintain order and rebuild Port Royal, renamed Annapolis Royal. The Treaty of Utrecht ushered in thirty years of peace beginning in 1713; it also permanently altered the balance of power in North America. France relinquished Hudson’s Bay, Newfoundland, and peninsular Acadia to Britain, but retained its colonies along the Gulf of St. Lawrence, on Île SaintJean (Prince Edward Island), and on Île Royale (Cape Breton). ${ }^{40}$ The Acadians prospered during this period of unprecedented peace and devoted their efforts to fishing and farming with minimal interference. Economic prosperity was accompanied by a marked increase in the birthrate as the Acadian population quadrupled to approximately eight thousand by 1750. Not all was well, however, as this period of peace also marked the Acadians' first experience of occupation; the Acadians were expected to become British subjects, an experience that was fraught with difficulty for both the occupiers and the occupied. ${ }^{41}$

\footnotetext{
${ }^{38}$ Griffiths, From Migrant to Acadian, 150-5; Daigle, “Acadia, 1604-1763,” 29. Oaths were a common part of seventeenth century law and politics. Oaths of allegiance were used throughout New England and New France, including when a colony was transferred from one empire to another. While oaths were taken seriously, they were not necessarily considered permanently binding and it was possible to renounce loyalty with a new oath. Duress and coercion were also taken into consideration when determining to what extent loyalty had been betrayed. Signed oaths held greater weight than their verbal counterparts.

${ }^{39}$ Daigle, "Acadia, 1604-1763," 30.

${ }^{40}$ Griffiths, From Migrant to Acadian, 253."

${ }^{41}$ Daigle, "Acadia, 1604-1763," 35-39.
} 
The British were immediately faced with the dilemma of how to govern their new possession where the majority of inhabitants were French-speaking Catholics. Unable to ascertain Acadian loyalties, the British lived in fear of an uprising and would never come to view the Acadians as trustworthy subjects. This fear was compounded when the influx of Anglo-Protestant settlers expected to rebalance the population failed to materialize. ${ }^{42}$ The Acadian reactions to these events were shaped both by their history and political geography. A border people in a neglected colony that had changed hands multiple times over the past century, the Acadians believed it was their right to control their own social and economic affairs. They were also hesitant to accept British authority, believing that the French might someday regain control of the territory, a judgement based on generations of experience in this atypical colony. ${ }^{43}$

Communication between the British and the Acadians also developed in a unique way to suit the local situation. When British officer Paul Mascarene met with the Acadians at Midas in 1710, they asked him to choose a number of men to represent the rest, as many resided in scattered settlements and had great difficulty attending such meetings. Mascarene willingly selected eight representatives from the various settlements. This was the beginning of the system of delegates which would act as Acadian representatives for the next forty-five years. According to Brebner, the delegates were effectively "the local government bodies of the Acadian population, and at the same time buffers between them and the English and the regular channel of communication."44 They were responsible for the preservation of order, for communicating the views of the

\footnotetext{
${ }^{42}$ Blake et al., Conflict \& Compromise, 72-73.

${ }^{43}$ Daigle, "Acadia, 1604-1763," 33-35; Griffiths, From Migrant to Acadian, 237-8.

${ }^{44}$ Brebner, New England's Outpost, 149.
} 
settlers to the administration, and for transmitting the orders and policies of the administration to the people. ${ }^{45}$ This system, according to Griffiths, demonstrates that the Acadians were politically organized, and it allowed them to maintain a degree of control over their own affairs while acknowledging the ultimate jurisdiction of the British officials. $^{46}$

One task of principal importance to the British administration was to make the Acadians British subjects by demanding that they swear an unqualified oath of allegiance. They attempted to administer the oath many times between 1710 and 1713 , even threatening the Acadians with deportation if they failed to comply. Recognizing that the British did not possess the means to carry through with this threat, the Acadians refused to comply unless certain reservations were included. ${ }^{47}$ It was not until 1730 that Governor Philipps succeeded in persuading the Acadians to take an oath. Convinced that a conditional oath was preferable to the status quo, Philipps amended a verbal promise to the oath, which stated that the Acadians would not be forced to take up arms against France or its First Nations allies. Nor would they take up arms against the British. The Acadians believed that they had acquired special status as neutrals and their behaviour during subsequent conflicts would comply with this. Future governors continued to

\footnotetext{
${ }^{45}$ Brebner, New England's Outpost, 149-50; Griffiths, From Migrant to Acadian, 240-1. Paul Mascarene was a bilingual British officer of Huguenot parentage. Many historians view his ability to speak French and willingness to accommodate and compromise as key to his ability to form positive relationships with the Acadians. The deputy system proved quite satisfactory to the British and they proceeded to regularize the system. Each community was assigned a quota of delegates to be selected from among the 'more reputable men of property'. Some of the more able delegates were eventually appointed to act as agents of government. The entire system was based on the need to improvise and adapt government to the local situation.

${ }^{46}$ Griffiths, Contexts of Acadian History, 40-43. While Griffiths and Roy believe that the Acadians were engaged in political life to a limited extent via the delegate system, Brebner is convinced that the Acadians were 'not politically minded' and neglects to consider the system as a potential political framework. See also Michel Roy, L'Acadie des origines à nos jours: Essai de synthèse historique (Montreal: Éditions Québec/Amérique, 1981), 96-99.

${ }^{47}$ Daigle, “Acadia, 1604-1763,” 37; Roy, L'Acadie des origines, 96-99.
} 
accept that the Acadians had been exempted from military service and most referred to them as 'the Neutrals' or 'the neutral French.' 48

Having taken the oath of conditional loyalty to the Britain, most Acadians chose to remain neutral when France and Britain found themselves on opposing sides during the War of the Austrian Succession in 1744. Griffiths believes that the community's previous experiences of alternating periods of French and British control led them to conclude that their situation would remain much the same regardless of the administration. ${ }^{49}$ The treaty which ended the war in 1748 marked a shift in British policy. Previously focused on trade and exploitation of resources, the British began to build up Nova Scotia as a counter to the French forces on the mainland and Île Royale. Governor Cornwallis arrived in 1749 with over 2,500 English and German Protestant colonists who settled near Halifax. Halifax was fortified and additional forts were constructed elsewhere. Meanwhile, the French were trying to recreate Acadia in what is now New Brunswick. Forts Beauséjour and Gaspéreau were constructed close to the intersection of French and British territory and the French soldiers forced a number of Acadians to move to French territory and swear unconditional loyalty to France. ${ }^{50}$

\footnotetext{
${ }^{48}$ Daigle, “Acadia, 1604-1763,” 37-38; Brebner, New England's Outpost, 90-97; Griffiths, Contexts of Acadian History, 41-42.

${ }^{49}$ Daigle, “Acadia, 1604-1763," 41; Griffiths, From Migrant to Acadian, 345. While the Acadians saw themselves as neutrals in this conflict, the French often tried to play upon what they believed was the Acadians' ultimate allegiance to the French monarchy while the British feared the Acadians sought to aid the French because of their common language and religion. For the most part, the Acadians simply wished to be left alone.

${ }^{50}$ Daigle, “Acadia, 1604-1763," 43-44; Brebner, New England's Outpost, 166-9. When the French ceded Acadia to the British in 1713, they only gave up the part of the territory that is now Nova Scotia, keeping what is now mainland New Brunswick as part of New France. While less populated than the peninsula, Acadians could be found along the east coast, the Bay of Fundy, and along the St John River. From this mainland base, the French and their First Nations allies raided into Nova Scotia causing trouble for the British and attempting to convince the Acadians to rise up against their new colonial masters.
} 
With tensions increasing between the British in Nova Scotia and the French surrounding it, the Acadians increasingly found themselves divided between two loyalties as neutrality became more difficult. In 1749 , Governor Cornwallis demanded that the Acadians take the unconditional oath of allegiance to Britain or forfeit their possessions and rights in the colony. The Acadians refused to comply, making their views known through their delegates. Cornwallis, finding his position untenable and fearing that any action taken against the Acadians would drive them into the arms of the French, decided to do nothing. It appeared to the Acadians that, once again, their position of neutrality had succeeded in rebuffing British attempts at administering an unqualified oath, with the expectations of military service that full allegiance to Britain entailed. The Acadian's position within the colony was, however, becoming increasingly precarious as both sides recognized the military value of the land where most Acadians resided. ${ }^{51}$

The appointment of Colonel Charles Lawrence as Lieutenant-Governor of Nova Scotia in 1753 marked an even greater shift in relations between the Acadians and the British. Lawrence's goal was to strengthen Nova Scotia as part of an overall campaign to preserve and expand British territory in North America. The outbreak of hostilities between the British and the French in 1754 provided him with the opportunity to capture the French Forts Beauséjour and Gaspéreau in the summer of 1755. When the French surrendered, some three hundred Acadians were found at arms in Fort Beauséjour. Despite assurances from the French commander that the Acadians had not joined the

${ }^{51}$ Griffiths, Contexts of Acadian History, 81-83; Griffiths, From Migrant to Acadian, 381-92. 
defence of their own free will, the British were not moved. This merely strengthened Lawrence's view that the Acadians posed a threat to the security of Nova Scotia. ${ }^{52}$

After the fall of Beauséjour, some Acadians petitioned Lawrence for the return of their boats and weapons, which had been confiscated to prevent them from aiding the French. The Acadians, who believed they had proved their neutrality, felt that they deserved to have their possessions returned. Lawrence and his council seized this opportunity to demand an unqualified oath of loyalty to the King. The Acadian delegates refused, but once again offered to take the qualified oath. No longer willing to accept anything less that the unqualified oath, the council ordered the Acadians be taken into custody. Daigle, Griffiths, and Roy agree that, by the spring of 1755, Lawrence "had become thoroughly convinced that his colony could not become a reliable outpost of the British empire while the Acadians were among its people." ${ }^{53}$ He believed that the best solution would be to send them to be assimilated in the other British colonies in North America. Their refusal to take the unqualified oath provided Lawrence with a reason for putting his plan into action. ${ }^{54}$

Their homes and farms confiscated by the British, the Acadians were herded on the waiting ships for deportation. The Acadian population was divided among the thirteen New England colonies. Often finding themselves unwelcome at their destinations, the Acadians were further subdivided in local communities both out of fear that they would cause trouble and so they would not present too much of a burden for the organizations

\footnotetext{
52 Brebner, New England's Outpost, 190-202; Daigle, “Acadia, 1604-1763,” 44-45; Griffiths, Contexts of Acadian History, 87-88.

${ }^{53}$ Griffiths, Contexts of Acadian History, 86. See also Daigle, “Acadia, 1604-1763," 44; and Roy, L'Acadie des origines, 128.

${ }^{54}$ Griffiths, From Migrant to Acadian, 455-62; Griffiths, Contexts of Acadian History, 88-91; Daigle, "Acadia, 1604-1763," 45.
} 
tasked with their welfare. In new lands surrounded by a language and religion that were foreign to them, the Acadians managed a meagre existence and continuously petitioned the local governments regarding the unjustified nature of their expulsion. They still considered themselves to be a distinct people and attempted to maintain a voice in their own destiny. ${ }^{55}$

Historians agree that isolation, the environment, and distinct local problems and conditions had resulted in the development of a distinctive Acadian society before the deportations began in 1755 . It is important to remember that the deportation was not an attempt to eradicate the Acadians but rather to absorb them in the dominant - anglophone - culture. ${ }^{56}$ In this respect, Lawrence's plan failed as the strength of kinship and community ties persisted despite geographic separation, and exile itself became a collective experience. A shared belief about why the deportation occurred and its impact on the community had developed by the end of the eighteenth century. This collective memory of deportation has become central to the identity of subsequent generations and would form a critical component of Acadians' ability to develop and maintain a distinct community upon their return to the Maritimes. ${ }^{57}$

${ }^{55}$ Daigle, “Acadia, 1604-1763," 45; Griffiths, Contexts of Acadian History, 89-94; Nicolas Landry et Nicole Lang, Histoire de l'Acadie (Sillery, QC: Septentrion, 2001), 93-94. Griffiths estimates that the predeportation Acadian population was approximately 12,000 individuals; an estimated 6,000 to 8,000 were affected by direct exile while others hid in the woods or fled to other French held territories. When Acadians were permitted to return to Nova Scotia, only between 1,000 and 2,000 remained in the colony. It is highly unlikely that the Acadians believed deportation was a possibility. Their relations with the British since 1713 had been rife with threats in attempt to bring about compliance, none of which were ever followed through. Not recognizing how much the situation had changed, the Acadians likely believed that they could wait out the war by maintaining their policy of neutrality. See Griffiths, Contexts of Acadian History, 76.

${ }^{56}$ While extermination was not intended, lack of food and water, poor sanitation, and storms at sea meant that over a third of the passengers on many ships perished before reaching their destinations. Many others fell victim to epidemics on arrival. See Landry et Lang, Histoire de l'Acadie, 91-92 and Griffiths, Contexts of Acadian History, 92-94.

${ }^{57}$ Griffiths, Contexts of Acadian History, 62-64, 96-97. 
The Seven Years War ended with the signing of the Treaty of Paris in 1763, which effectively saw the end of French imperial power in North America. In 1764, the Acadians were permitted to return to Nova Scotia on condition that they take the oath of allegiance and that they settle in small groups. Their ability to negotiate terms was severely limited and they could no longer rely on nearby French territories for support, so those who wished to return submitted themselves to the oath of fidelity. This was likely done with little joy or conviction. ${ }^{58}$

Acadians were unable to return to their former homes as these desirable agricultural lands had already been given to settlers from New England. The Acadians had the option of settling in established communities on lands reserved for them or to found new, albeit small and dispersed, settlements. Seeking to put distance between themselves and their old enemies, the Acadians preferred to settle among their own people in remote areas further from the centres of British control, where they could attempt to rebuild a new Acadia with minimal outside interference. ${ }^{59}$ Those who chose to settle in what would become New Brunswick in 1784 inhabited the northern and eastern shores and the lower St. John River Valley. Those who settled near Fredericton were once again dispossessed of their lands and forced to move north with the arrival of the Loyalists between 1784 and $1786 .^{60}$ By the end of the eighteenth century, approximately 36 percent of Acadians had returned to the Maritimes, a return that continued into the

\footnotetext{
${ }^{58}$ Léon Thériault, La question du pouvoir en Acadie: Essai, Deuxième édition (Moncton, NB: Éditions d'Acadie, 1982), 23-24; Léon Thériault, "Acadia, 1763-1978 An Historical Synthesis," in The Acadians of the Maritimes: Thematic Studies (Moncton, NB: Centre d'études acadiennes, 1982), 48; Roy, L'Acadie des origines, 153.

${ }^{59}$ Landry et Lang, Histoire de l'Acadie, 128-31; Thériault, La question du pouvoir, 23-24; W.S. MacNutt, New Brunswick, a History: 1784-1867 (Toronto: MacMillan, 1963), 3.

${ }^{60}$ Thériault, “Acadia, 1763-1978," 49.
} 
1820s. While the Acadians once again had a place to call home, the Acadian community had little structure and would exist at the margins of society for many years. ${ }^{61}$

In the early years after the Acadians' return, farming was largely subsistence based. Both out of preference and necessity Acadians often diversified their modes of production based on what was available where they lived. Logging was a common occupation, for at least part of the year, in inland areas. Along the coasts, shipbuilding and fishing were common. These occupations saw Acadians selling their labour to the mainly Anglo-Protestant owned companies in exchange for low wages which confined them to a cycle of poverty and servitude. ${ }^{62}$

Religious life suffered from a shortage of trained priests since Acadian churches were no longer able to depend on recruitment from France. To make matters worse, the Quebec bishops did not hold the Acadians in high regard, often blaming them for their own deportation. This resulted in few Quebec priests being sent to serve amongst the Acadians; those who did come served as missionaries over vast territories. Acadians often had to make do with anglophone priests or lay clergy. Relaxation of exclusionary laws against Catholics in 1783 made recruitment a bit easier as did the French Revolution of 1789, which saw a small number of priests come to New Brunswick after being forced out of France. By 1861, there were only six francophone priests in New Brunswick, two of whom were Acadian, a number that would increase significantly in the next few decades with increases in population and local recruitment into the priesthood. Despite

${ }^{61}$ Landry et Lang, Histoire de l'Acadie, 131; MacNutt, N.B. History, 6; Griffiths, Contexts of Acadian History, 95-96; Thériault, La question du pouvoir, 24-25. The Acadians were not granted title to their new lands because of laws preventing Catholics from holding property. In 1783 the law was altered to make it fairer towards Catholics, largely as a result of requests by the Irish Catholic community.

${ }^{62}$ Landry et Lang, Histoire de l'Acadie, 148-55. 
making up a large percentage of the province's Catholics, no francophone bishops were appointed. These positions went to Irish Catholics. ${ }^{63}$

Prior to the 1820 s, the priests and missionaries were the most educated people in Acadia because schools were few. Early traveling teachers and priests occasionally taught lessons out of local homes. The New Brunswick government began limited funding for schools in 1805, although they made no provisions for French-language education.

Around 1820, parish schools began to open in Acadian communities to preserve the French language; however, these schools often lacked adequate funding, teachers, and textbooks. In 1858, the government passed the Parish School Act which provided for the construction and funding of Catholic schools in Acadian and mixed communities. The classes were taught in French, mainly using French textbooks imported from Quebec. The first institution of higher learning, Séminaire St. Thomas, opened near Memramcook in 1854 to train leaders for the Acadian community. Plagued by funding difficulties, it was forced to close in 1862, but would reopen as Collège Saint-Joseph in $1864 .{ }^{64}$

It was relatively easy for the Acadian voice to be excluded from debates on education and other important matters as the population was excluded from, and then severely underrepresented in, political circles. To ensure the Anglo-Protestant character of government in eighteenth century New Brunswick, voters and elected officials were required to swear an oath which denounced various principles of the Catholic faith, effectively disenfranchising all Catholics, francophone or otherwise. The oath

\footnotetext{
${ }^{63}$ Landry et Lang, Histoire de l'Acadie, 138-41.

${ }^{64}$ Landry et Lang, Histoire de l'Acadie, 141-42; Alexandre J. Savoie, "Education in Acadia: 1604 to 1970," in The Acadians of the Maritimes: Thematic Studies (Moncton, NB: Centre d'études acadiennes, 1982), 391-402. English language schools were also poorly equipped and organized at this time especially outside of the major centres. Enrollment was low as attendance was restricted to students whose parents could pay the school tax. Many Acadians were poor with large families, they were frequently unable to afford to educate their children. Only 20 percent of Acadian children attended school.
} 
requirement for voters was not abolished until 1810 but was still required of those running for the Legislature until 1830, when all religious oaths were abolished. Acadians were represented by anglophones throughout this period. Doucet attributes the lack of Acadian representation to the underdeveloped Acadian elite and middle classes which were beginning to emerge and become politically aware by the $1860 \mathrm{~s} .{ }^{65}$

The political gap between anglophones and francophones in New Brunswick continued into the 1860 s and the debates over Confederation. The Confederation debate was particularly hard fought in New Brunswick, resulting in two referenda in 1865 and 1866 as the division between pro and anti-federalists was drawn along religious and linguistic lines. ${ }^{66}$

Confederation was a political decision, but the influence of the Catholic Church on the debate surrounding unification should not be underestimated. While the Quebec bishops supported Confederation, clerical opinion in the Maritimes was varied and shifted over time. In 1865, the Catholic opposition, both Irish and Acadian, which amounted to 35 percent of the population, played a major role in the defeat of New Brunswick's pro-federalist government in the first referendum. The Acadian and Catholic majority counties of Westmorland, Kent, Northumberland, Gloucester, Madawaska, and Victoria all elected anti-Confederation candidates. After the first referendum, some legislature members accused the parish priests of encouraging the Acadians to reject Confederation; however, this was not entirely true as some priests supported

\footnotetext{
65 Philippe Doucet, "Politics and the Acadians," in The Acadians of the Maritimes: Thematic Studies (Moncton, NB: Centre d'études acadiennes, 1982), 226-32; Thériault, “Acadia, 1763-1978," 50-51. Doucet states that a lack of access to education is the main reason for this underdevelopment.

66 Thériault, "Acadia, 1763-1978," 60; Doucet, "Politics," 232; Chantal Richard, "Acadian Collective Identity Before and After Confederation: The Case of New Brunswick Acadians," Canadian Issues, (Fall 2014): 25 .
} 
Confederation and encouraged their parishioners to do the same. Undoubtedly, many other Acadian priests, who believed that Confederation would not be beneficial for New Brunswick and the Acadians, encouraged their churches to vote against these measures. ${ }^{67}$ Given that no means of written mass communication was available in New Brunswick the first French-language newspaper would not be founded until 1867 - it was common for the clergy to convey messages and advise parishioners on matters of importance. ${ }^{68}$

By the time of the 1866 referendum, Catholic opposition to Confederation had fractured. The Archbishop of Halifax became convinced Confederation was necessary and one of New Brunswick's two bishops followed suit. The Acadians and some of their priests remained firmly opposed to Confederation, but this time francophone-majority ridings were the only ones to elect anti-federalist candidates. ${ }^{69}$ That the Acadian vote had been responsible for the election of anti-Confederation candidates did not escape the attention of anglophone New Brunswick. The Telegraph wrote that without the "ignorant and illiterate" French vote, no anti-federalist candidates would have been elected. ${ }^{70}$

Richard states that the Acadians opposed Confederation, in part, because their language rights had been ignored. Quebec citizens retained the right to use either language in Parliament and federal court, while its anglophone minority was granted linguistic protection and the right to maintain denominational schools. Even though the Acadians formed a sizeable demographic segment within New Brunswick, they were not

${ }^{67}$ Thériault, "Acadia, 1763-1978," 60-63; Doucet, "Politics,” 232-38.

${ }^{68}$ Richard, "Acadian Collective Identity," 25. The first French-language newspaper in New Brunswick, Le Moniteur Acadien, was first published on July 8, 1867.

${ }^{69}$ Phillip Buckner, "Beware the Canadian Wolf: The Maritimes and Confederation," Acadiensis 46, no. 2 (2017): 183. New Brunswick's Irish Catholic population had followed the advice of the archbishop and supported Confederation.

${ }^{70}$ MacNutt, N.B. History, 453-54. 
consulted, and their language and religious rights were not granted protection.

Confederation was seen as tantamount to assimilation. ${ }^{71}$

With the founding of the Dominion of Canada, Acadians found themselves a smaller minority within a larger country, this however did not stall the nascent Acadian Renaissance movement, which only became stronger into the 1880 s. It was during this period that community and political leaders and a national conscience emerged which would lift Acadians out of the poor, illiterate, and voiceless state in which they found themselves for nearly a century since their return to the Maritimes. ${ }^{72}$

Acadians played a minimal role in New Brunswick politics until Confederation, after which, political interest, and a desire for representation began to increase as part of the Acadian Renaissance. The number of Acadian representatives increased gradually until it became roughly proportionate to their share of the population following the Second World War. ${ }^{73}$ Acadians were also initially underrepresented at the federal level both in Parliament and the Senate. The first Acadian was elected to Parliament in 1878, and by the twentieth century, Acadians had been elected to represent the ridings of Restigouche-Madawaska, Gloucester, and Kent. The first Acadian Senator, Pascal Poirier, was appointed to the Senate in March 1885. The second and third Acadian Senators, Thomas-Jean Bourque and Onésiphore Turgeon, were appointed in 1917 and 1922. Since that time, francophone New Brunswick has typically been represented by three Senators and three MPs. ${ }^{74}$

\footnotetext{
${ }^{71}$ Richard, "Acadian Collective Identity," 26.

72 Doucet, "Politics," 243-44.

${ }^{73}$ Doucet, "Politics," 246-47.

${ }^{74}$ Doucet, "Politics," 247-49; Landry et Lang, Histoire de l'Acadie, 196.
} 
By 1870 , the New Brunswick government was seeking to improve the deplorable state of education within the province. Only children whose parents had paid school fees were eligible to attend classes, a system which barred poor children from attending including many from Acadian families. The government passed the Common School Act in 1871 , which was to provide free education for all children. The act made no mention of French language education, but, much to the chagrin of the province's Catholic population, an addition to the act forbade religious instruction and religious symbols in schools. Believing the provision of denominational religious education to be of prime importance, New Brunswick's bishops, both Irish Catholics, forbade parishioners to pay the school tax or to send their children to the public schools. As good Catholics, the Acadians complied and vigorously protested the act. The act largely wiped out the publicschool system in Acadian and Catholic areas. Instead, Acadians set about establishing their own French-language school system by opening convent schools to complement the pre-existing Acadian colleges. ${ }^{75}$

Events took a turn for the worse in 1875 in the small village of Caraquet. Tensions flared between the small anglophone minority and the Acadian majority after the Acadians were barred from the district school board for failure to pay the school tax. When a group of disgruntled Acadians began to intimidate supporters of the act, the anglophone Legislative Councillor, Robert Young, called the sheriff to arrest the Acadians. The sheriff and his men, all Anglo-Protestants, set about arresting the

\footnotetext{
${ }^{75}$ Savoie, "Education in Acadia," 403-10; Landry et Lang, Histoire de l'Acadie, 169. Savoie points out that the convent schools provided much better instruction in English and French that the public schools. At public schools in English speaking communities, children received instruction only in English while in mixed communities, French-speaking public-school students learned neither English nor French well. This hampered young francophones' ability to find good jobs, seek further education, and improve the status of their communities.
} 
Acadians. ${ }^{76}$ A group of Acadian men hid in the attic of a house out of fear they were the next to be arrested. Pushing their way into the home, the sheriff's men began to shoot through the ceiling upon hearing noises coming from the attic. The Acadians managed to fire back several shots before surrendering. John Gifford, one of the sheriff's men, and an Acadian, Louis Mailloux were killed. The surviving Acadians were arrested. No charges were laid in the death of Mailloux, but nine Acadians were charged with murder in connection with Gifford's death. The case went all the way to the Supreme Court, which concluded that the charges should be dismissed due to several procedural errors. ${ }^{77}$ The incident resulted in rapid changes to the school system. Nuns and priests would be permitted to teach in public schools dressed in religious garb and religious lessons would be permitted after school hours. Other amendments permitted the use of French language textbooks in certain subjects at the primary level. This incident can be interpreted as a sign of rising Acadian self-awareness and continued animosity between the French Catholic and Anglo-Protestant communities. ${ }^{78}$

Doucet asserts that the Acadian reawakening was largely a result of the Church and its efforts to develop teaching institutions. Collège Saint-Joseph, established near Memramcook in 1864, finally made it possible for Acadians to undertake higher education in their own language, despite the restrictive provincial education policies. The founding of the first Acadian newspaper, Le Moniteur Acadien, in 1867 was also both a cause and effect of the Acadian renaissance and developing middle class. The newspaper sought to inform Acadians about political issues of importance and also acted as a forum

\footnotetext{
${ }^{76}$ A number of the anglophones involved were reported to be members of the Loyal Orange Lodge which was well known at the time for its hatred of all things francophone and Catholic.

${ }^{77}$ Richard Wilbur, The Rise of French New Brunswick (Halifax, NS: Formac, 1989), 24-37.

${ }^{78}$ Wilbur, Rise of French, 37-38; Savoie, "Education in Acadia," 405-7.
} 
for the exchange of ideas among the small body of leaders that had emerged from Collège Saint-Joseph. These factors and the experience of the Acadian delegates to the conference of the Société Saint-Jean-Baptiste in Quebec inspired the Acadians to hold their own national congress. ${ }^{79}$

The first Acadian National Convention was held at Collège Saint-Joseph on 20 and 21 July 1881 . Over five thousand people attended the convention, but only several hundred participated in the discussions about agriculture, colonization, the problem of emigration, education, journalism, and representation in the Church. The Société nationale l'Assomption was founded to act as the voice of the Acadian people. The most contentiously debated issue was the selection of an Acadian national holiday. Some delegates advocated for Saint-Jean-Baptiste out of solidarity with Quebec, while others believed Acadians should have their own separate holiday, the Assumption. ${ }^{80}$ They pointed out that shared language, religion, and origins already united French Canadians; and now Confederation united all the peoples of Canada. While unification might be favourable to the development of a nation, it was essential that all groups be able to maintain their own collective identity within the larger framework. Despite their initial rejection of Confederation, the Acadian delegates believed that it could help to maintain Acadian distinctiveness since all citizens were equal under the constitution. Delegates frequently asserted that they were only seeking the same rights and privileges which were already being enjoyed by other Canadians. ${ }^{81}$ The Acadian flag and national anthem, Ave Maris Stella, were selected at the Miscouche convention in 1884, which continued the

\footnotetext{
${ }^{79}$ Doucet, "Politics," 243-5; Thériault, "Acadia, 1763-1978," 70.

${ }^{80}$ Thériault, "Acadia, 1763-1978," 70-71; Landry et Lang, Histoire de l'Acadie, 189-90; Richard, "Acadian Collective Identity," 26.

${ }^{81}$ Richard, "Acadian Collective Identity," 26-28.
} 
work begun at the first convention. Altogether ten conventions were held between 1881 and 1913. Further efforts to increase Acadian representation in the Church and improve the education system stemmed from discussions at these conventions. ${ }^{82}$

As part of their efforts to increase representation in the Church, community leaders sought the appointment of the first Acadian bishop. A growing Acadian population, coinciding with a falling number of Irish Catholics, lent weight to their request since New Brunswick's two bishops were both of Irish descent. Petitions, newspaper campaigns, and direct appeals to the Vatican all attempted to secure the nomination of an Acadian bishop. Their hopes were dashed in 1899 when the five Maritime bishops, meeting to name successors for the bishops of Chatham and Saint John, nominated Irishmen to both posts. This led to protests by the Acadian press, and most Acadian priests boycotted the induction ceremony. To Acadians this seemed like a deliberate attempt to hold onto power by the church hierarchy. The issue was resolved in 1912, when Rome appointed Édouard Leblanc as the bishop of Saint John. In the following years, Acadian representation within the church hierarchy increased as new parishes and dioceses were created. ${ }^{83}$

During the First World War, the conflict between francophones and anglophones in New Brunswick shifted focus from concern over religion and education to issues of military service and loyalty to Britain. In the early years of the war, it was reported that New Brunswick was enlisting approximately five hundred men per month; however, by 1916, the ready supply of recruits was diminishing. When the Borden government made plans to implement conscription for overseas service in 1917 , the issue immediately

\footnotetext{
82 Thériault, “Acadia, 1763-1978," 71-73.

${ }^{83}$ Landry et Lang, Histoire de l'Acadie, 207-9; Wilbur, Rise of French, 53-55, 70-78.
} 
proved divisive within the province. A large segment of the anglophone population supported the measures, and a large number of Acadians, some Irish Catholics, fishermen, and farmers opposed them. While francophones were not alone in their opposition to conscription, “Canada's linguistic struggles left many Anglos with the erroneous impression that only the French opposed conscription." ${ }^{84}$ The press and public speakers increasingly spouted inflammatory and divisive rhetoric as the December 1917 federal election approached. ${ }^{85}$

People on both sides of the conscription debate in New Brunswick attempted to make themselves seem more dedicated to the cause of winning the war by distinguishing themselves from, and vilifying, the opposition. Anglophone New Brunswickers frequently used this tactic to lump Acadians together with the other French Canadian 'slackers' who, the anglophones claimed, had not done their duty by enlisting in sufficient numbers under the voluntary recruitment system. ${ }^{86}$ In late November 1917 , the Daily Gleaner reported that there was "only one distinctive French-Canadian battalion fighting" and that English Canadian parents had sacrificed ninety-one of their sons

\footnotetext{
${ }^{84}$ Wilbur, Rise of French, 114. Recent immigrants from Britain made up a sizeable proportion of those who enlisted for overseas service. Men born in Canada - both anglophones and francophones - proved more reluctant to enlist.

${ }^{85}$ Most of New Brunswick's English-language press was supportive of conscription although some Catholic and Liberal papers sided with Liberal leader Sir Wilfrid Laurier on conscription but supported voluntary enlistment. In the French language press, the Conservative Le Moniteur Acadien supported conscription while the Liberal L'Acadien opposed it; Le Madawaska and L'Évangéline maintained a more neutral stance. Many Anglo-Protestant ministers promoted conscriptionist views from the pulpit while the Catholic church was divided. Bishop Leblanc of Saint John promoted voluntary participation but did not make his views on conscription known.

${ }^{86}$ Andrew Theobald, The Bitter Harvest of War: New Brunswick and the Conscription Crisis of 1917. (Fredericton, NB: Goose Lane Editions, 2008), 83. The anglophone newspapers were not alone in their failure to consider Acadians and other French Canadians outside Quebec as a separate demographic. In his study of patriotism and dissent, Millman considers French Canada as a homogenous block centred around Quebec and united by its shared language, ethnicity, and religion. No mention is made of the Acadians. See Brock Millman, Polarity, Patriotism, and Dissent in Great War Canada, 1914-1919 (Toronto: University of Toronto Press, 2016), 58-65.
} 
compared to only four from French Canada. ${ }^{87}$ This statement completely ignores that an Acadian battalion, the $165^{\text {th }}$, was recruited in the province and that numerous Acadians joined anglophone units. ${ }^{88}$ In his study of conscription in New Brunswick, Theobald insists that Acadians did not oppose the war any more than other rural Canadians. Rather it was the recruiting system which failed to address them in their own language and communities. Recruiting was conducted primarily in English with recruiting centres often located far from francophone population centres. Most of the units being raised were anglophone and unilingual. Formation of the $165^{\text {th }}$ Battalion was intended to demonstrate Acadian loyalty to the British Empire and emphasize the distinctiveness of Acadian identity from that of English and French Canada. The breakup of this battalion meant the loss of a symbol for the Acadian community, which may have made others less likely to enlist. $^{89}$

Unwilling to sit passively while the anglophone population ignored their contributions to the war effort, Acadians responded through their own newspapers. L'Évangéline declared that it had become a habit for certain English language papers and pro-conscription politicians to throw insults at Quebec, and French Canadians in general, under the pretext that francophones had not enlisted in sufficient numbers, and that these

\footnotetext{
${ }^{87}$ Daily Gleaner, November 23, 1917, 8. The Royal 22e Régiment was the only official French-Canadian battalion serving together at the front. There were several other attempts to recruit francophone units; however, these units were broken up in England and France to be used as reinforcements. For example, the $165^{\text {th }}$ Battalion was broken up as reinforcements for two forestry units. Many francophone recruits throughout Canada also joined anglophone units, preferring to fight alongside others from their hometowns regardless of language.

${ }^{88}$ Theobald, Bitter Harvest, 44-46. It is difficult to tell exactly how many Acadians served during the First World War. Attestation papers were normally in English and did not ask the recruit's mother tongue.

Historians, such as Jean Martin, have attempted to calculate the number of Acadian servicemen based on names and hometowns and lists of those known to have served.

${ }^{89}$ Theobald, Bitter Harvest, 43-46.
} 
anglophones had spared no effort to arouse racial prejudices in their denunciations. ${ }^{90}$ The anglophone denunciation of all francophones as slackers was made all the more unreasonable by the actions of the Acadian elite, who publicly supported conscription. In a Senate speech, Acadian Senator Thomas-Jean Bourque stated that it seemed the appropriate time to pass the Military Service Act as immediate reinforcements were needed. ${ }^{91}$ In his own lengthy Senate speech, Senator Pascal Poirier also declared his support for the MSA, stating that, while he had been opposed to the idea in the past, the existing threat to democracy caused him to rethink his position. ${ }^{92}$

Unlike in Quebec, opposition to conscription and support for voluntary enlistment coexisted in the Acadian population. Despite anglophone beliefs to the contrary, francophone sources maintain that a good number of young men enlisted. ${ }^{93}$ The Acadians also supported the war effort in other ways. A number of Acadians who worked in the fishing industry, as lumberjacks, and as farmers believed that they could support the war effort more effectively by producing essential commodities at home. Although many were poorer than their anglophone counterparts, Acadians also contributed large sums to the war effort. ${ }^{94}$

Whether they voted based on their own conscience, or the advice of local politicians, clergy, or newspapers, the results of the December 1917 election revealed that the overwhelming majority of Acadians were opposed to compulsory service. Not a

${ }^{90}$ L'Évangéline, November 21, 1917, 1.

${ }^{91}$ L'Évangéline, August 29, 1917, 2. The speeches of Acadian senators and MPs were printed regularly in the French language press.

${ }^{92}$ L'Acadien, August 7, 1917, 2; L'Évangéline, September 26, 1917, 2; L'Évangéline, October 3, 1917, 2.

${ }^{93}$ Landry et Lang, Histoire de l'Acadie, 237-39.

${ }^{94}$ Theobald, Bitter Harvest, 48-49. The improving economic situation as a result of the war also worked to keep Acadians at home. Men could earn more at home than by enlisting; this prospect of financial gain was a powerful motivating factor in many cash strapped Acadian communities. Acadians also married younger and had larger families and New Brunswick had no plan to support dependents or wounded soldiers. 
single Union candidate was returned in a francophone-majority riding. ${ }^{95}$ Despite disagreeing with the decision to implement the MSA, there were no riots or public demonstrations in francophone areas of New Brunswick after conscription was imposed. L'Acadien and the other French language papers encouraged each young man eligible for call up under the MSA to register as the law required, but to apply for an exemption from service if he felt that he would be of greater use to the war effort by continuing to serve on the home front. ${ }^{96}$ While many applied for exemptions, there were significantly fewer attempts made by Acadians to evade the draft than in Quebec. ${ }^{97}$ Acadian newspapers told their readers that it was in their best interest to comply with the regulations since not doing so would exacerbate tensions between the province's linguistic communities. The experience of expulsion in 1755 was never far from the surface of Acadian consciousness. Acadians understood better than Quebec that disloyalty, or even perceived disloyalty, could have drastic consequences for a minority.

With the high degree of animosity which existed between francophones and anglophones in New Brunswick during the First World War, it was no surprise that relations continued to be strained throughout the interwar period. The first Acadian premier, Pierre-Jean Veniot, was appointed in 1923 upon the resignation of his predecessor. Yet he was unable to win the following provincial election. Anglophones had taken note of the impact of the Acadian vote in December 1917 and whispered fears of 'French domination' circulated during subsequent provincial election campaigns. Ku Klux Klan circulars made their way around the province during the 1930s, and during the

\footnotetext{
95 Thériault, “Acadia, 1763-1978," 81.

${ }^{96}$ L'Acadien, November 6, 1917, 1.

${ }^{97}$ Millman, Polarity, Patriotism, and Dissent, 183-88.
} 
1935 provincial election, a letter allegedly written by a Klan official urged voters not to cast their ballots for Catholic candidates. ${ }^{98}$

Throughout the interwar years, the main source of conflict between anglophones and francophones was the school system and the use of French in educational and public environments. Following the compromises of the 1871 Common School Act, some improvements were made, including the introduction of a few additional French and bilingual textbooks. But the state of French language education still lagged behind the anglophone system. A point frequently made in Le Moniteur Acadien, L'Évangéline and by the Société nationale l'Assomption. Fearful of angering their anglophone neighbours, Acadian leaders advocated moderation and the situation remained largely unchanged until the 1920 s. ${ }^{99}$

Between 1922 and 1926, a group known as La Petite Boutique worked to improve the French language educational system. The group published a review, Le Madawaskaien, which succeeded both in renewing interest in French language education and in raising concerns among anglophones, who saw the increased use of French in schools as a threat to their language rights and position of socio-economic superiority. ${ }^{100}$ During a meeting with government officials, the prominent Acadian teacher and promoter of French education, Calixte Savoie, overheard one official explaining to another that the Acadians' educational requests were being refused because 'C $\mathrm{C}$ 'est en les gardent dans l'ignorance que nous pourrons mieux les dominer. Donnez-leur l'instruction et vous mettez entre leurs mains l'arme la plus puissante pour sortir de la pauvreté Culturelle et

\footnotetext{
${ }^{98}$ Wilbur, Rise of French, 148; Thériault, “Acadia, 1763-1978," 78.

${ }^{99}$ Savoie, "Education in Acadia," 405-6.

${ }^{100}$ Savoie, "Education in Acadia," 413-4.
} 
économique dans laquelle ils se trouvent." ${ }^{101}$ Undaunted, members of La Petite Boutique and the committee on language and education of the Société nationale l'Assomption continued to lobby the Board of Education. Their efforts appeared to have paid off in August 1928 when the Board of Education announced the implementation of Regulation 32, which permitted local school boards to adopt bilingual programs. All teachers at these schools would be required to pass a French exam.

The victory would be short-lived. In December, the Grand Master of the Orange Lodge sent a letter to all lodges in the province protesting the encroachment of the French language and French Catholic church on a unilingual anglophone province. The letter provoked an intense backlash from the Anglo-Protestant community. The Conservative government chose to repeal Regulation 32. Instead, it established a commission to study the provincial education system. The findings of the commission indicated that francophone students were disadvantaged by the educational system and made several recommendations for improvement. The recommendations were never implemented. The government cited lack of funding as a result of the Depression, but Calixte Savoie believed that it was reluctant to incur the wrath of the Orange Lodge and anglophone voters. $^{102}$

The Depression years were difficult for New Brunswick’s Acadian community. Acadians, for the most part, were dependent on anglophones for jobs and were often among the first to be dismissed as the Depression worsened. Since anglophones owned most businesses and transactions were conducted in English, there was little incentive to hire bilingual employees. To combat high unemployment and decreasing use of French,

\footnotetext{
${ }^{101}$ Calixte F. Savoie, Memoires d'un Nationaliste Acadien. (Moncton, NB: Éditions d'Acadie, 1979), 145.
}

${ }^{102}$ Savoie, Memoires, 155-79; Savoie, "Education in Acadia," 413-4. 
the Société nationale l'Assomption organized the Campagne de Refrancisation to encourage Acadians to demand services in French at local businesses and from the government. It was hoped that an increase in the demand for French services would encourage the hiring of French-speaking employees. In the spring of 1934, the campaign appeared to be achieving results with some stores hiring bilingual clerks, but a group called the English-Speaking League formed to resist the Campagne de Refrancisation which, it was claimed, cost anglophones their jobs. Afraid of provoking greater retaliation and the possible loss of the few concessions which had been obtained in recent years, some of the Acadian leaders backed down. ${ }^{103}$

Acadian students were still leaving school without an adequate command of English or French and dropout rates remained high. Textbooks for most subjects were in English and many students resorted to memorization of pages of material that they could not understand. Pedagogical methods taught at the Normal School remained inappropriate for the teaching of francophone students. The return of the Liberal party to power in 1935 emboldened the Acadian education critics and the New Brunswick branch of the secret society, l'Ordre de Jacques Cartier, to campaign for improvements to French language education in public schools. In 1936, the OJC helped to form a new lobby group, l'Association acadienne d'éducation, in an attempt to achieve the reforms that had almost been won under Regulation 32. Through continued meetings with government officials and engagement with the public through the French and English language press, the association was successful in raising awareness of the deplorable state of French language education in the province. In 1939, a report tabled in the legislature provided

${ }^{103}$ Savoie, Memoires, 153, 194-210; Wilbur, Rise of French, 144-7. 
official recognition of the inequalities between French and English schools. There was an increase in French language instruction at the Normal School and the association began to offer a privately funded French summer school for teachers. Other concessions would follow throughout the 1940s and 1950s, but conditions would not improve substantially until an Acadian, Louis J. Robichaud, became premier in June $1960{ }^{104}$

As this chapter demonstrates, the history of conflict between anglophones and francophones in New Brunswick stretches back almost to the founding of settlements in what was once Acadia. During this period of over three hundred years, from 1604 to 1939, the conflict took on many forms from raids, open warfare, and expulsion during the age of empires to economic, religious, and educational discrimination related to language differences in more modern times. No matter the method used, actions taken to destroy or assimilate the francophone community ultimately failed, and instead brought the community closer together, united by shared experience and resolve to withstand pressure from the majority. Nor would the experience of past wrongs, dating back to the deportations and beyond, be forgotten as they formed an integral part of Acadian identity. Subsequent chapters will demonstrate that their previous experiences of conflict with the anglophone majority would play a significant role in fostering the community's response to the Second World War and the conscription crises of 1942 and 1944.

\footnotetext{
${ }^{104}$ Wilbur, Rise of French, 149-58; Savoie, "Education in Acadia," 414-7. For a detailed account of the activities of l'Association acadienne d'éducation, see Savoie, Memoires, 231-286.
} 


\section{Chapter Two}

\section{The First Conscription Crisis}

Memories of the social and political turmoil of conscription which divided Canadians along linguistic lines during the Great War and caused a great divide in the ranks of the Liberal Party were never far from the mind of Prime Minister William Lyon Mackenzie King in the late 1930s. Preservation of national unity would be of utmost importance in the impending conflict. With Quebec likely favouring neutrality and English Canada in favour of involvement alongside Britain, King recognized that neutrality would not be possible if Britain declared war on Germany, but he remained reluctant to commit to any policy which guaranteed support for a European war. $\mathrm{He}$ recognized the need for caution and was committed to preserving the appearance of Canada's independent national status. If war was to be declared, Parliament would decide. ${ }^{105}$ King was, however, ready and willing to commit on one aspect of wartime policy in the interests of preserving Canadian unity. In his lengthy address in the House of Commons on 30 March 1939, King declared that in the event of a future war "conscription of men for overseas service would not be a necessary or an effective step. Let me say that so long as this government may be in power, no such measure will be enacted." ${ }^{\prime 106}$ While avoiding conscription for overseas service was something which King believed was necessary for the preservation of unity and convincing Quebec to fight for Canada, the timing of his statement was undoubtedly influenced by Conservative party leader R.J. Manion's declaration two days earlier that he did "not believe Canadian youth

\footnotetext{
${ }^{105}$ Granatstein, Canada's War, 4-8.

${ }^{106}$ House of Commons, Debates, 30 March 1939, 2426.
} 
should be conscripted to fight outside the borders of Canada." ${ }^{107}$ With the world on the brink of war, Manion's statement, meant to appease French Canadians, also served to alienate some members of his own party who believed that compulsory service was necessary and would be effective. ${ }^{108}$

Following the German invasion of Poland on 1 September, King recalled Parliament to meet on 7 September and at the same time declared that a state of apprehended war had existed since 25 August, permitting organization for the defence of Canada and recruitment of military forces. Canada would go to war, but Parliament would decide the scope and mechanisms of Canada's participation, King informed the public in a radio broadcast. On 8 September, he repeated his 30 March promise to the House of Commons not to resort to conscription for overseas service. Despite some neutralist and anti-war sentiment, mostly from Quebec members, Parliament was almost unanimously behind King, and Canada officially declared war on Germany on 10 September 1939, seven days after Britain and France had done so. While Canada had gone to war of its own accord, politicians at the time and historians since have recognized that they actually had very little choice in the matter. Many Canadians retained significant cultural and ancestral ties to Britain, not to stand at Britain's side would have been unfathomable. In addition, remaining legal and economic ties with Britain would have made neutrality difficult. ${ }^{109}$

\footnotetext{
107 Toronto Star, 28 March 1939.

108 Norman Hillmer, O.D. Skelton: A Portrait of Canadian Ambition (Toronto: University of Toronto Press, 2015), 306-9; Granatstein and Hitsman, Broken Promises, 126-8.

${ }^{109}$ Granatstein and Hitsman, Broken Promises, 133; Granatstein, Canada's War, 12-19; Ralph Allen, Ordeal by Fire: Canada, 1910-1945 (Toronto: Doubleday Canada, 1961), 362-4.
} 
With Britain assured of Canada's participation, the government prepared the country for war. Mackenzie King was determined that this war would be different from the last. Canada would not be bled of men or materiel; conscription and national disunity were to be avoided at almost any cost. This would be a war of limited liability with military participation largely subordinate to economic aid, primarily in the form of foodstuffs and industrial goods. ${ }^{110}$ Nor was the war greeted with the same fervour in the population as it had been in 1914. Unlike a generation before, the cheering and public displays of enthusiasm were conspicuously absent, replaced by a grim determination and understanding of the sacrifices which would need to be made. The Canadian public showed few signs of outright opposition to the conflict, but the Quebec press was divided in its opinion on the war. ${ }^{111}$

In New Brunswick, whatever reservations might have been held by the population remained far from the pages of the local newspapers. On 2 September, the Daily Gleaner reported that "All branches of the armed forces have been placed on an active service footing during the state of "real or apprehended war."' In addition to the Permanent Force and headquarters staffs, Militia units were to be mobilized at their local headquarters. Those units subsequently called up would be responsible for manning coastal defences, guarding vulnerable points, and providing an all-arms reserve force. The article reassured readers, in the event that an expeditionary force was to be raised, that the militia structure would be preserved, avoiding the disorganization of $1914 .{ }^{112}$ Public sentiment was similar to that displayed across the country: "with the grim realisation of war looking

\footnotetext{
${ }^{110}$ Granatstein, Canada's War, 19; Granatstein and Hitsman, Broken Promises, 134.

${ }^{111}$ Granatstein, Canada's War, 19-21. Anti-war demonstrations took place in a few Quebec cities in 1939.

112 "Canadian Active Service Force Now Being Organized," Daily Gleaner, 2 September 1939, 4.
} 
them in the face members of the Non-Permanent Militia units in Fredericton were ... flocking to the Armoury to join the colors."113 "A" Company of the Carleton and York Regiment and $90^{\text {th }}$ Field Battery had already set up recruiting offices in the capital, and $89^{\text {th }}$ Field Battery in Woodstock was recruiting personnel. The two other militia units in the area were not recruiting but had been selected for guard duty. ${ }^{114}$

Despite the sombre tone with which Canadians greeted the war, local recruiting centres were flooded with men willing to enlist. On the morning of 4 September, less than three days after the start of recruitment, "A" Company of the Carleton and Yorks were reporting that they had already reached full wartime strength. A local rector and police magistrate were among those who had enlisted. While the company was slated to join the rest of the regiment on Island Park in Woodstock, a recruiting detail would remain behind with new orders to accept all the men who were fit and willing to enlist. The supply of men vastly outpaced that of resources, with local units struggling to provide recruits with uniforms and accommodations. ${ }^{115}$

The population of Madawaska County was among the first to experience the war firsthand. On 31 August, Le Madawaska published an article explaining that ten thousand soldiers from the Non-Permanent Active Militia (NPAM) were sent to guard waterways, railroads, factories, and other vulnerable areas throughout the country, especially along the Atlantic and Pacific coasts and the St. Lawrence, protecting them from potential saboteurs. ${ }^{116}$ Some of the guards were posted at vulnerable sites in Madawaska County. An article on the cover of the edition for 7 September stated that the three Germans

\footnotetext{
113 “Two Local Units Now Recruiting to Full War Strength,” Daily Gleaner, 2 September 1939, 12.

114 “Two Local Units Now Recruiting to Full War Strength,” Daily Gleaner, 2 September 1939, 6, 12.

115 "Recruits Flock to Swell Local Units Past Full Strength," Daily Gleaner, 4 September 1939, 6, 12.

116 "Les endroits vulnérables sont gardés," Le Madawaska, le 31 août 1939, 7.
} 
arrested in the St. Léonard area a few weeks earlier had escaped from the local prison. The trio had attempted to cross the river into the United States. One, who had nearly drowned, decided to return to prison of his own accord, the second was arrested by US Immigration officials, and the third was arrested by four local militiamen who had been assigned to guard the town post office. All three were successfully returned to prison. ${ }^{117}$ While a minor occurrence, events such as these served to keep the population on guard as Germany brought the war to Canada's doorstep. U-boats sank or damaged dozens of ships in the waters off the coast of the Maritime provinces, Newfoundland, and in the Gulf of St. Lawrence. One U-boat even managed to land a spy near New Carlisle, Quebec, just across the Baie des Chaleurs from New Brunswick. ${ }^{118}$

Ronald Cormier writes that Acadians “n'ont pas à cette époque de veritable tradition militaire," despite New Brunswick's having several NPAM units. All of them conducted training in English and contained few Acadians, most Acadians who served during the First World War having since left the military. ${ }^{119}$ However, in 1939, Acadians appeared just as willing to enlist as their anglophone counterparts. Le Madawaska described the scene at the Edmundston train station in early September when the first group of eighty-three recruits left the city to join their regiment in Woodstock. A large

117 “Les 3 Allemands ramenes à la prison," Le Madawaska, le 7 septembre, 1939, 1. A direct translation of the article suggests that the Germans had escaped or ran away from Germany however, under the circumstances it is unclear whether this was true or whether they were attempting to escape to Germany or had been landed in the area to act as German agents; Cormier, Acadiens et la Seconde Guerre, 19-20.

${ }_{118}$ Roger Sarty, The Maritime Defence of Canada (Toronto: Canadian Institute of Strategic Studies, 1996), 205; Brian Tennyson and Roger Sarty, Guardian of the Gulf: Sydney, Cape Breton, and the Atlantic Wars (Toronto: University of Toronto Press, 2000), 280-1.

${ }^{119}$ Cormier, Acadiens et la Seconde Guerre, 60. Here Cormier cites a statistic from the 1931 census which states that among the 768 members of the armed forces in the Maritimes, only 50 were francophones, 48 of whom were serving in Nova Scotia. While he does not say the numbers involved suggest this statistic does not include the NPAM. My newspaper research indicates that by the late 1930s, New Brunswick francophones were involved with the NPAM although in small numbers. 
part of the town's population had gathered to send them off. All of the soldiers who volunteered for active service were members of D Company, Carleton and York Regiment, which was headquartered in the city. While officially an anglophone regiment, D Company, which recruited in the upper Saint John River Valley, traditionally had a much larger percentage of francophones than the rest of the regiment. The paper listed the names of all eighty-three departing soldiers, many of whom had names that were distinctively francophone. Interest in enlistment was ongoing and two more, albeit smaller, departures were planned. ${ }^{120}$ The community appeared fully supportive of young men who chose to enlist. The Edmundston school board voted in a resolution to ensure that employees who left their jobs to enlist would be returned to the same position which they held prior to enlistment. In addition, the board would grant them a month's salary, a significant display of support in a district which was not overly well funded. ${ }^{121}$

The Acadians' preference for volunteerism in all matters relating to wartime participation was established very early in the war. During the discussion regarding the creation and administration of a Canadian Patriotic Fund, Kent MP Louis Robichaud objected to the language in one section of the bill, which, he believed, suggested that contributions to the fund might be obligatory. Robichaud insisted that mandatory collection of funds during the previous war had caused resentment among the people, suggesting that, if the government ensured all contributions to such funds were voluntary, the measures would be better received by the people. ${ }^{122}$

\footnotetext{
120 “Soldats partent à la gare d'Edmundston," Le Madawaska, le 7 septembre 1939, 1, 6.

121 "La commission scolaire et le service militaire," Le Madawaska, le 7 septembre, 1939, 1.

${ }^{122}$ House of Commons, Debates, 11 September 1939, 125-6. Neugent also discusses how important voluntary, as opposed to obligatory contributions to the war effort, were for Acadians. See Nugent, "The Acadian Response," 50-51.
} 
In La Voix d'Évangéline's first wartime issue, the editor approved the government's policy of limited participation and emphasized that the participation of Canada and of Canadians was voluntary, as Canada had declared war of its own accord. While the situation indicated that King was intending to keep his promise not to impose conscription, the editorial warned that this state of national unity might not last, especially if the desires of English Canadians clashed with French Canada's well-known opposition to coercive measures. The editor wrote that peace between francophones and anglophones must be a national priority "que la guerre dure six mois ou six ans ... [et qu'ils] ne s'infligent pas des blessures qu'il serait difficile de guérir par la suite."123 Conscious that public sentiment towards conscription could change as the war dragged on, Acadians kept abreast of statements by politicians in other provinces concerning conscription. In the Quebec provincial election in the fall of 1939, voters overwhelmingly rejected Maurice Duplessis' Union Nationale government in favour of Godbout's Liberal Party. This was largely a result of assurances by Quebec's federal Liberal ministers, Ernest Lapointe, C.G. (Chubby) Power, and Pierre Cardin, that they would never accept conscription for overseas service but would resign their posts if Duplessis was re-elected. This, they claimed, would open the doors for conscriptionists both in Parliament and the Cabinet, ultimately bringing about conscription. AngloCanadians at the time misinterpreted Duplessis' defeat as a sign that Quebec was fully supportive of the war effort when it was the result of ongoing anxiety about the possibility of conscription. ${ }^{124}$ While the Acadian papers did not focus on the election itself, it appears that they were reassured by the statements of the Quebec ministers.

123 “Le Canada est en guerre avec l'Allemagne," La Voix d'Évangéline, le 14 septembre 1939, 3.

${ }^{124}$ Granatstein and Hitsman, Broken Promises, 135-6. 
Under the heading "Pas de Conscription," Le Madawaska reprinted Lapointe's statement that he and ministers Cardin and Power "ne consentirons jamais à la conscription, que nous ne serons jamais members d'un Gouvernement qui essaiera d'appliquer la conscription et que nous n'appuierons jamais un tel Gouvernement."125

Concern and disagreement over the government's handling of the war effort increased in 1940. When most of the Liberal and all of the Conservative members of the Ontario legislature, led by Liberal Premier Mitchell Hepburn, passed a resolution denouncing what they considered to be inadequate support for the war effort on the part of the Federal Government, there was cause for concern in New Brunswick. Lucien Fortin, the editor of Le Madawaska, struck back, saying that Premier Hepburn "et les partisans de la conscription qui l'entourent ont manifesté une fois de plus leur zèle intempestif pour la guerre." He accused the politicians of acting as part of a campaign "en vue d'accélérer advantage la participation du pays et d'amener la conscription." 126

On 1 February, Fortin again took aim at Hepburn and his compatriots. He called them imperialists who would never be satisfied with Canada's war effort "que lorsque le Canada aura conscript tout sa puissance et son sang au service de l'Empire." Fortin applauded King's efforts in adopting a conciliatory policy which was limited to material assistance and voluntary service, but lamented that, because of his policies of limited liability, "[il] a servi de cible naturelle à ce groupe d'ultra-participationnistes qui veulent que le Canada se saigne à blanc pour que vivre 1'Empire." ${ }^{127}$ Although there was clearly a

\footnotetext{
125 "Pas de conscription," Le Madawaska, le 12 octobre 1939, 7.

126 “L'Incident Hepburn-King,” Le Madawaska, le 25 janvier 1940, 3.

127 "Le gouvernement veut l'appui d'un mandate bien défini," Le Madawaska, le 1 février 1940, 3. See also "L’Incident Hepburn-King," Le Madawaska, le 25 janvier 1940, 3, 13.
} 
large proportion of the population, consisting of more than just French Canadians, who still supported moderate participation, fault lines were beginning to be drawn.

King saw the opportunity posed by Hepburn's rash actions and called a snap election, hoping to catch the opposition Conservatives unprepared. This was also a move which he believed would demonstrate the public's faith in his wartime policy as well as providing a mandate which would prevent him from having to face the electorate at a more politically difficult time in the future, as had occurred in 1917. King's strategy was effective at catching his opponents off guard and disorganized and without the necessary funds to run a campaign. Manion's Conservatives came out both in favour of a national government and in opposition to conscription, neither of which proved to be effective election issues for the party. Both the Liberals and the Cooperative Commonwealth Federation $(\mathrm{CCF})$ refused to consider involvement in a national government led by Manion, while the concept of national government itself reminded many voters of Robert Borden's Union Government in 1917, inextricably linked with conscription. Manion's promises not to institute conscription, no matter how many times they were uttered, failed to convince Canadians. ${ }^{128}$

In its post-election editorial, Le Madawaska concluded that the election had principally been fought on the conscription issue and while both major parties came out against it, they did not offer the same guarantees. Editor Lucien Fortin cited Manion's policy of increased participation and his criticisms of King as being incompatible with his anti-conscription promises, making for the belief among certain parts of the electorate

128 J.L. Granatstein, The Politics of Survival: The Conservative Party of Canada, 1939-1945 (Toronto: University of Toronto Press, 1967), 39-48. 
that the Conservatives were more likely to impose conscription than Mackenzie King. ${ }^{129}$ Unable to secure funding through their usual channels in Montreal, the Conservatives also found themselves drastically short of cash to assist their candidates. This was likely one reason for the lack of Conservative election advertisements in the New Brunswick papers, to the regret of the New Brunswick Conservative MP, R.B. Hanson. ${ }^{130}$

With no trouble securing funds, Liberal advertising appeared frequently in the pages of the newspapers. The Liberal campaign focused on the war effort. The government took credit for the implementation of Canada's wartime commitments, military, domestic, and economic. It claimed that Canada's contribution was much more organized than it had been in 1914 and that the government could help win the war without putting Canadian interests in peril. All of the Liberal election advertising stressed that a vote for the Liberals was a vote for Canadian unity. ${ }^{131}$ The timing of the election was also of immense benefit to the Liberals; there were few calls for increased participation or conscription with Canadian troops sitting idle in Britain. Canadians were clearly content with the government's strategy of moderate involvement. ${ }^{132}$

The result of the election was a landslide victory for Mackenzie King and the Liberals, who won 184 seats compared with the Conservatives' 40. In New Brunswick, the vote was more evenly split, with both parties winning five seats. The Liberals took seats in all ridings with sizeable Acadian populations. Three Acadians were elected in the

\footnotetext{
${ }^{129}$ Éditorial, "Le verdict de mardi dernier," Le Madawaska, le 28 mars 1940, 3, 11.

${ }^{130}$ Granatstein, Politics of Survival, 49-50.

131 "Unite nationale," Le Madawska, le 8 février 1940, 1; Annonce électorale "Pas de Victoire sans chefs éprouvés," Le Madawaska, le 14 mars 1940, 11. Manion had written in his 1936 autobiography that he believed conscription was the "best and fairest way to raise men for war." This likely would not have helped him convince the population that he was against conscription in the present war. See Granatstein, Canada's War, 89.

${ }^{132}$ Granatstein, Politics of Survival, 48.
} 
constituencies with the largest number of francophones: J.E. Michaud in RestigoucheMadawaska; Clarence Veniot in Gloucester; and Aurel Léger in Kent replaced Robichaud who did not stand for re-election. ${ }^{133}$ By giving King a clear mandate, Fortin concluded that the population had pronounced its approval of King's policy of limited liability. Lauding King as the political heir of Laurier, Fortin cautioned that "respect de la parole donnée assurera au parti liberal la reconnaissance du people canadien et évitera à celui-ci de revivre les jours pénibles de 1917."134 In other words, the population had given King a mandate based on his promises concerning the conduct of the war - and he was expected to keep them.

The German invasion of Belgium and France in May 1940 brought an end to Mackenzie King's policy of limited liability. As much military aid as possible was prepared to assist with the defence of Britain and strategic points in North America, but King was initially reluctant to resort to national service along the lines of the Emergency Powers Act passed in Britain. By mid-June, the worsening situation in France, combined with increased calls for national registration and even outright conscription, led the government to change its mind. It was King himself who drafted the National Resources Mobilization Act, which was introduced in the House on 18 June and speedily passed into law on 21 June. ${ }^{135}$ The NRMA gave the government the power to compel individuals to place themselves and their property at the service of the state as required for the war effort. Most importantly, these special powers were limited by the third section of the act, which stipulated that it "may not be exercised for the purpose of requiring persons to

\footnotetext{
133 "Grande victoire Liberale," Le Madawaska, le 28 mars 1940, 1.

134 Éditorial, "Le verdict de mardi dernier," Le Madawaska, le 28 mars 1940, 11.

135 Granatstein and Hitsman, Broken Promises, 140-3.
} 
serve in the military [,] naval or air forces outside Canada and the territorial waters thereof." ${ }^{136}$ Canada now had conscription, albeit in a limited form.

Historians have stated that there was relatively little opposition anywhere in Canada to the passage of the NRMA, even though this represented an easing of the government's anti-conscription policy. ${ }^{137}$ With only Britain standing between Canada and Nazi expansionism, it was easy for most Canadians to see that the security of Canada was being threatened. Articles found in the New Brunswick papers in the summer of 1940 reflected this sentiment. The Daily Gleaner reported on the expansion of Canada's war plans, with an additional 30,000 recruits needed immediately for the army, 5,000 for the air force, and nearly 5,000 for the navy. ${ }^{138}$ Le Madawaska reported that "le bill n'emploie pas le mot conscription et ne comporte pas le pouvoir de censcrire pour le service outremer, mais uniquement pour le service au pays. C'est une mesure de service obligatoire pour la défense du pays." ${ }^{139}$ Recruiting in Fredericton and across the province was reopened after having been suspended for some weeks. Discouraged from enlisting earlier in the war, specialists and tradesmen were in high demand and recruiters were met with a rush of applicants which far exceeded the number of positions available and overwhelmed the capacity of the local military administration to house and clothe them. ${ }^{140}$

Le Madawaska focused on providing its readers with practical advice on manpower requirements and the upcoming national registration. Articles explained why

\footnotetext{
136 Statutes of Canada, The National Resources Mobilization Act, Chapter 13, 1940.

${ }^{137}$ Byers, Zombie Army, 43-44; Granatstein and Hitsman, Broken Promises, 143-4.

138 "For Expansion of Canada's War Plans," Daily Gleaner, 28 May 1940, 4; "Canadian Navy to Enlist 4,000 Men," Daily Gleaner, 25 May 1940, 9.

139 "Mobilization générale au Canada," Le Madawaska, le 20 juin 1940, 9.

140 "Recruiting in Fredericton Has Been Resumed," Daily Gleaner, 22 May 1940, 12; "Barrack

Accommodations are Overtaxed; Specialists Wanted," Daily Gleaner, 21 June 1940, 12.
} 
national registration was being undertaken and who would be liable for service under the NRMA. ${ }^{141}$ Over the following weeks until registration took place on 19-21 August, articles by local journalists explained how the registration process would work at the local level. The questionnaire that residents would fill out on registration day was published in French and English, as well as a copy of the registration certificate. ${ }^{142}$ On 8 August, an editorial republished from a Winnipeg newspaper explained that registration “est une decision juste et opportune du gouvernement de l'Etat ... cette initiative gouvernementale n'ait pas pour but primordial de mener à la mobilisation, ell indiquera avec exactitude le nombre de ceux qui sont aptes au service militaire et celui des personnes qui ne le sont pas." "143 Another article in the same edition of Le Madawaska declared that registration was necessary so that workers could be directed where they were most needed to improve wartime production. No mention was made of compulsory service. ${ }^{144}$ All citizens were encouraged to comply with the policy, and it seems as if most of them did so. ${ }^{145}$ Neither francophone nor anglophone New Brunswickers were inclined to oppose measures put in place for the defence of Canada. The only media record of opposition to any of the measures was a report about a group of Jehovah's Witnesses from Quebec who were arrested in Campbellton for distributing literature likely to prejudice recruiting. ${ }^{146}$

\footnotetext{
141 “Enregistrement national," Le Madawaska, le 18 juillet 1940, 1, 6.

142 “Texte du questionnaire de l'enrégistrement," Le Madawaska, le 25 juillet 1940, 11; "L'inscription nationale etablira le bilan de nos resources," le 8 août 1940, 11. The same form was also published in English on 1 August, 6. "Voici le certificate d'inscription que vous recevrez," Le Madawaska, le 15 août $1940,8$.

${ }^{143}$ Éditorial "L'enregistrement national," Le Madawaska, le 8 août 1940, 3.

144 “Pourquoi faut-il s'inscrire le 19?" Le Madawaska, le 8 août 1940, 7.

145 “Toute personne de 16 ans et plus devra s'enrégistrer," Le Madawaska, le 15 août 1940, 1.

146 “Jehovah's Witnesses Arrested in Campbellton," Daily Gleaner, 10 August 1940, 3; “Jehovah's

Witnesses Guilty of Distributing Subversive Literature,” Daily Gleaner, 11 August 1940, 2.
} 
In late August, the government announced that bilingual training camps for men called up under the NRMA would be constructed in Ontario, Quebec, and New Brunswick. One of these bilingual centres would be in Edmundston and Fredericton would house an English only centre. According to National War Services, francophones were to be sent to camps staffed with francophone or bilingual instructors as often as possible. ${ }^{147}$ The editor of La Voix d'Évangéline initially applauded this decision, stating that training in their own language was essential for francophone recruits to become effective soldiers, but he wondered whether Acadians in Nova Scotia and Prince Edward Island would be granted the same opportunity. ${ }^{148}$ In the coming weeks, he was dismayed to learn that the Edmundston training centre was only for recruits from the northern counties of Madawaska, Restigouche, Gloucester, and Northumberland. Francophone recruits from other parts of the province were forced to do their training in Fredericton entirely in English regardless of their language capabilities. In a series of three editorials in October and November, the editor called on the government to make changes and allow francophones to train in the language of their choice, but to no avail. It was becoming apparent that, while the government and the military were promising greater equality and opportunities for francophones, these promises were often not reflected in reality. ${ }^{149}$

\footnotetext{
147 "Un camp d'entrainement militaire à Edmundston," Le Madawaska, le 22 août 1940, 12; "Des officiers C.-français commanderont ces camps," Le Madawaska, le 5 septembre 1940, 1, 7.

148 "Des camps d'entrainement bilingues en Ontario, au Québec, au N.-Brunswick," La Voix d'Évangéline, le 19 septembre 1940, 3 .

149 "Un camp bilingue mais pour qui?" La Voix d'Évangéline, le 10 octobre 1940, 3; "Encore à propos du seul camp bilingue au N.B.," le 17 octobre 1940, 3; "Si le système est bon pour les comtésé du nord ...," le 7 novembre 1940, 3. It was possible for New Brunswick Acadians from outside of the four northern counties to train in Edmundston if they requested this change of training centre without delay upon receiving their call up notice. However, they were not informed of this possibility and it seems that most were not aware of it, instead reporting to the training centre listed on their call up notice regardless of their level of English language proficiency.
} 
Until NRMA and Active service volunteers began to do basic training together in 1941, all Acadians who volunteered to serve in New Brunswick units did their basic and advanced training in English. This caused significant difficulties for many unilingual francophones, such as Joseph LeBouthillier, who joined up with a group of forty francophones from the Acadian Peninsula in 1941. They arrived in Fredericton for training not knowing any English and had great difficulty understanding the instructors and making themselves understood. ${ }^{150}$ These language struggles were not unique to the military experience. Throughout the war years, Acadian papers published multiple articles which discussed francophone language rights and the manner in which these were frequently overlooked by the anglophone majority. ${ }^{151}$

The first NRMA recruits began their thirty days of training on 9 October 1940. It was widely understood that thirty days was insufficient to provide a recruit with even the rudimentary basics of soldiering, with four months being the recommended minimum, so training focused on fitness, drill, and marksmanship, with the goal of selling the army way of life to encourage enlistment among the trainees. A message from the Minister of National Defence, received at the training centres emphasized that "a great deal depends on first impression, and we want recruits to feel by the way they are received and looked after from the moment they come into camp that their accommodation, outfitting and

\footnotetext{
${ }^{150}$ Ronald Cormier, "J'ai vécu la guerre”: Témoignages de soldats acadiens 1939-1945 (Moncton, NB: Les Éditions d'Acadie, 1988), 128.

${ }^{151}$ Acadians were not opposed to learning English but rather to the way that their language rights were ignored. As indicated in the previous chapter, the state of French language education in the province was such that francophones left school oftentimes at a young age without a good knowledge of either English or French. There were also limited opportunities for francophones and in francophone majority areas and most were low paying. Successive governments showed very little inclination to fix these issues.
} 
training have been the subject of careful planning." 152 The initial impression of trainees arriving at No. 71 Canadian Army (Basic) Training Centre is unknown but, as staff arrived only five days earlier to find the buildings "in an unfinished state," it was likely that the camp was still in a state of disarray. ${ }^{153}$ On 31 October, the training centre war diary reported that the staff had succeeded in making "order out of chaos in this camp," in making "soldiers out of men who had never done any military duty," and "in creating a most favorable impression amongst the civilian population." ${ }^{\prime 54}$ The next day it reported an increased demand for pamphlets and other literature, which "gladdens the hearts of our instructors who note a growing interest in Army life on the part of our Trainees." 155 Le Madawaska reported favourably on No. 71 CA(B)TC. Articles were designed to put trainees and their families at ease, assuring them that quality food would be provided and that a chaplain had been assigned to the camp. A recreation hut sponsored by the Knights of Columbus was constructed and local citizens groups frequently organized musical soirées, dances, and other forms of entertainment. ${ }^{156}$ The Daily Gleaner also reported on what trainees were learning at No. 70 CA(B)TC.

\footnotetext{
${ }^{152}$ Library and Archives Canada (LAC), RG 24-C-3, Vol. 17258, File 1252, Folder 1. Lieutenant Colonel R.L.H. Goodday to the Officers Commanding of No.70 and No.71 Militia Training Centres, 7 October 1940.

${ }^{153}$ LAC, RG 24-C-3, Vol. 17258, File 1252, Folder 1. War Diary Summary of Events, 4 October 1940.

${ }^{154}$ LAC, RG 24-C-3, Vol. 17258, File 1252, Folder 1. War Diary Summary of Events, 31 October 1940.

${ }^{155}$ LAC, RG 24-C-3, Vol. 17258, File 1252, Folder 1. War Diary Summary of Events, 1 November 1940. While reports that many trainees were interested in enlisting appeared at many training centres, there were no measures yet in place to transfer them to the Active army nor to ensure they paraded with the NPAM units to which they were assigned after completing their 30 days of training. However, the Daily Gleaner did report that some members of the first 30-day training group had submitted applications for enlistment in various branches of the military.

156 "Une hutte des Chev. De Colomb au camp local," Le Madawaska, le 3 octobre 1940, 1, 6. "Le menu des camps d'entrainement," Le Madawaska, le 3 octobre 1940, 1, 7. "Le camp local à maintenant son aumônier," Le Madawaska, le 17 octobre 1940, 1. "Reception aux recrues du camp local," Le Madawaska, le 5 decembre 1940, 9 .
} 
The thirty-day training program was merely an intermittent measure designed to show Canadians that the government was doing something to defend the country and to attempt to appease conscriptionists by obliging men to serve. ${ }^{157}$ In reality, partially trained soldiers were of no benefit to the war effort. Eventually the General Staff persuaded the Cabinet to agree to a four-month compulsory training program, beginning in March 1941. The new program would see volunteers for overseas service (Active or Arecruits) and conscripts (Reserve or R- recruits) take basic and advanced training together, a move, it was hoped, which would encourage some R-recruits to volunteer. This 'encouragement' to go active became more profound, especially as the number of volunteers gradually began to decline. As a result of this decline, less than a month after the start of the four-month program the Cabinet War Committee agreed to retain NRMA trainees for the duration as members of home defence units. This would free up more active members for service overseas. ${ }^{158}$ None of the papers recorded any dissent about the new policy.

In May 1941, the federal government launched its first official recruitment campaign of the war. This was also the first time that Acadians as a group were targeted by military recruiters. Coinciding with the start of the campaign, French language recruiting advertisements began to appear in the newspapers. Like many of the English recruiting advertisements, the French language versions attempted to appeal to recruits' sense of patriotism, masculinity, and desire for adventure. Other articles stressed the

\footnotetext{
${ }^{157}$ E.L.M Burns, Manpower in the Canadian Army 1939-1945 (Toronto: Clarke, Irwin \& Co., 1956), 117.
}

${ }^{158}$ Granatstein and Hitsman, Broken Promises, 148-51. 
benefits of military service and answered questions frequently asked by prospective recruits. ${ }^{159}$

The French-language papers began to publish photos and stories of Acadian families with large numbers of sons and daughters who had volunteered. It was not uncommon for Acadian families to have four or five siblings who had enlisted. La Voix d'Évangéline reported that one woman from Shediac had seven sons in the army. Another article reported that a Kent County family had seven sons and two sons-in-law who were serving. That both of these stories appeared on the front page is indicative of an eagerness to prove that Acadians were participating in the war effort on a level similar to that of their anglophone counterparts. ${ }^{160}$

While the recruitment campaign eventually did meet its objective, it was evident that the tempo of recruiting had slowed since the early months of the war. Subsequent events would conspire to bring the conscription issue to the forefront once again. While pro-conscription sentiment had never disappeared, the return of Arthur Meighen to the leadership of the Conservative Party, accompanied by his call for the "formation of a non-party government" and "compulsory selective service over the whole field of war," ${ }^{161}$ unleashed the conscriptionist sentiment and led to ever more vocal calls for conscription from the English language press, prominent citizens, and politicians. ${ }^{162} \mathrm{New}$ Brunswick Liberal Premier J.B. McNair questioned the "advisability of the limitation of

\footnotetext{
159 “Les avantages de l'enrôlement dans l'armée Canadienne," La Voix d'Évangéline, le 3 juillet 1941, 12. 160 "Sept frères, des Acadiens, dans l'armée," La Voix d'Évangéline, le 31 juillet 1941, 1; "Sept fils, deux gendres: neuf soldats," La Voix d'Évangéline, le 9 octobre 1941, 1.

161 "Meighen to Lead Conservatives," Daily Gleaner, 13 November 1941, 2. This article stated that Meighen did not specifically mention conscription for overseas service, but the translation of Meighen's words in La Voix d'Évangéline reads "le service militaire obligatoire sur une base selective pour tout théâtre de guerre". This would likely be understood as meaning for overseas service which would have made francophones especially anxious.

${ }^{162}$ Granatstein and Hitsman, Broken Promises, 153-6,162.
} 
compulsory military duties to Canada" and whether leaving it to the individual to determine where he or she could be of greatest service was an efficient way of managing the war effort. ${ }^{163}$

With conscription becoming the ultimate symbol of engagement in total war, King became aware that his promises not to impose conscription could become a problem if casualties were high following the invasion of the continent. ${ }^{164}$ As early as November 1941, he began to consider a plebiscite on conscription. A plebiscite would give the population an opportunity to express its views on conscription for overseas service and, if favourable, would provide the means by which the government could extricate itself from its promises if and when the need arose. Alongside growing conscriptionist sentiment, the expanding army programme and Japan's entry into the war in December further increased concerns over manpower. A plebiscite, King believed, would allow him to bide his time and see how the situation evolved. Thus, a plebiscite to release the government "from any obligations arising out of any past commitments restricting methods of raising men for military service" was announced on 22 January 1942, with its date set for 27 April. ${ }^{165}$

While the word conscription would be conveniently and conspicuously absent from the question on the ballot, there was no doubt to what it referred. King tried to reassure Canadians that a yes vote would not signal immediate imposition of conscription but would merely give the government free reign to do so in the unlikely event that the need arose. The announcement, however, was immediately polarizing. Québécois nationalists rapidly organized for a no vote. Even some Conservatives were initially

\footnotetext{
163 “M’Nair Questions Limiting Service,” Daily Gleaner, 13 January 1942, 2.

164 J.L. Granatstein, Conscription in the Second World War 1939-1945: A Study in Political Management (Toronto: Ryerson Press, 1969), 40.

${ }^{165}$ House of Commons, Debates, 22 January 1942, 2.
} 
hesitant to support one of Mackenzie King's initiatives, but unwilling to see conscription

defeated, they threw their support behind the yes campaign. ${ }^{166}$

New Brunswick newspapers attentively followed discussions in Ottawa surrounding the plebiscite by reprinting speeches given in the House of Commons and information about local organization during the campaign. In Fredericton, the selection of articles printed in the Daily Gleaner demonstrates clear support for the yes campaign throughout April 1942. Conservative House Leader and local MP R.B. Hanson played a major role in the organization of a General Campaign Committee alongside the Fredericton branch of the Legion and other concerned citizens. ${ }^{167}$ Over one hundred individuals, including women and members of the local clergy, were present at the formation of the committee which was intentionally non-partisan, and in addition to Hanson, included Liberal Premier McNair and former federal Liberal candidate P.J. Hughes, who was elected chairman. One attendee, a veteran of the First World War, told other participants that their "task was to go out and organize as they had never organized before." The committee urged a united front and that "there must be an all-out contribution from every individual if we were going to win [the war]."168

Coverage of the yes campaign extended to other areas of the province. The Daily Gleaner reported that various communities throughout Carleton County were organizing

\footnotetext{
${ }^{166}$ Both Meighen and Hanson were initially against holding the plebiscite, they believed that this was a "dangerous delay and hindrance" to the war effort and that the government should simply propose a clearcut policy and have Parliament decide the matter as it would be more straightforward, "Hon. R.B. Hanson On Plebiscite Vote," Daily Gleaner, 21 April, 1942, 4.

167 "York-Sunbury Has Campaign on Coming Federal Plebiscite," Daily Gleaner, 6 April 1942, 7, 10. The committee organized by Hanson does not appear to be the only group campaigning for a Yes vote in the Fredericton area. The York-Sunbury Plebiscite Committee under Chairman W.J. West was also working in the city and surrounding rural areas; see "Last Minute Work in Organizing for Plebiscite Now On," Daily Gleaner, April 25, 1942, 12.

168 “Affirmative Campaign for Federal Plebiscite Starts," Daily Gleaner, 11 April 1942, 5.
} 
for a yes vote and that meetings were well attended, with numerous men and women speaking and showing great interest. In northern New Brunswick, attendees at a meeting at the Bathurst Curling Rink were unanimous in their support for a yes vote. Citizens were urged to volunteer their cars to assist on polling day, while the Red Cross and Imperial Order Daughters of the Empire (IODE) were to help in every way possible. There was no mention of the linguistic identity of the Bathurst attendees; however, the heavy involvement of the IODE suggests that it was largely an anglophone affair. ${ }^{169}$

Local politicians were vocal and visible advocates of the yes campaign. Hanson spoke on the plebiscite in a CBC Radio broadcast on the evening of 20 April. He reminded voters that a yes vote was not a vote for Mackenzie King, but a vote upholding Canada's duty to "play her full part in the conquest of the forces of evil." Hanson warned that "a negative vote would, by restricting Canada's war effort, endanger her own shores." ${ }^{170} \mathrm{He}$ left Ottawa on 22 April to spend the rest of the week in his home riding of York-Sunbury, lending his voice to the regional committees campaigning for a yes vote. ${ }^{171}$ Premier McNair spoke to a large and enthusiastic crowd on 19 April at the Capitol Theatre in Woodstock. He stressed that the vote was not for or against conscription, but about giving Parliament free reign to make such a decision. He stated that it was hard to imagine that anyone in the province would "register a negative vote on that question ... [especially considering] the marvellous record of the people of New Brunswick, of all races and creeds in enlistments, in the Victory Loan campaign and other war activities." If anyone was in doubt of the need for an all-out war effort, the

\footnotetext{
169 "Plebiscite Campaign in Carleton County," Daily Gleaner, 20 April 1942, 2. "Gloucester County Organizes for 'Yes'," Daily Gleaner, 23 April 1942, 9.

170 "Hon. R.B. Hanson on Plebiscite Vote," Daily Gleaner, 21 April 1942, 4.

171 “Hanson Will Campaign in Riding,” Daily Gleaner, 23 April 1942, 1.
} 
Premier continued, "let him view the conditions which exist to-day in the subjugated countries of Europe.... Let him too remember Hong Kong. And let him reckon our chances for success in this battle for freedom if Canadians are driven to do their main fighting on Canadian soil." 172 According to their papers, New Brunswick's anglophone community was of the opinion that the plebiscite was necessary to give Parliament the freedom to pursue the war effort in any way necessary. To not grant Parliament this permission by voting no was to put the war effort and the very freedom of Canada and Canadians in jeopardy.

The Daily Gleaner's coverage of the no campaign was minimal and mainly confined to a couple of articles which reported on the plebiscite campaign in Quebec. One article explained that it was likely that Quebec would vote no. ${ }^{173}$ A second article described how several Quebec Liberal MPs had asked their constituents to vote no. ${ }^{174}$ In the only sign of opposition to the yes vote within the province, the Daily Gleaner printed an article from Moncton which indicated that no vote pamphlets and window stickers appeared in that city on 25 April. Some had been mailed in Montreal, others were postmarked Moncton. No one was able to ascertain the number of pamphlets in circulation, but a number of prominent citizens, including the mayor and the police chief, had received copies. They, along with others, reported destroying the pamphlets immediately after receiving them, an action indicative of the anglophone public's

\footnotetext{
172 "Premier J.B. M'Nair Spoke at Woodstock," Daily Gleaner, 20 April 1942, 7. For full text of the speech see PANB, RS414 D5a1a, Records of the Office of Premier John B. McNair, Addresses 1942-1946, Speech: Plebiscite Meeting at Woodstock, 19 April 1942.

173 "The Quebec Vote on the Plebiscite," Daily Gleaner, 11 April 1942, 7.

174 “Quebec People Urged to Vote No,” Daily Gleaner, 14 April 1942, 3. The article stated that Liberal MPs Maurice Bourget of Lévis, Louis Phillippe Lizotte of Kamouraska, Jean François Pouliot of Temiscouata, and Maxime Raymond of Beauharnois-La Prairie had all encouraged a no vote.
} 
reaction. ${ }^{175}$ Other than this one incident, it appears that the newspaper was entirely oblivious to any opposition in the province to the yes campaign. All of their articles from francophone regions had focused on individuals advocating for a yes vote. ${ }^{176}$

Like the Daily Gleaner, La Voix d'Évangéline and Le Madawaska closely followed the plebiscite campaign as it unfolded, albeit with significantly increased attention paid to the francophone point of view and to the views of the Acadian MPs. Both papers reprinted the statement of Gloucester Liberal MP Clarence Veniot, made in the House of Commons on 11 February, in what Le Madawaska called "un des meilleurs discours prononcés à la Chambre des Communes sur le sujet de la conscription et du plebiscite." He maintained that Acadians were as loyal as any other Canadians. However, their loyalty did not stem from ties to Europe or to the Empire, as language represented French Canadians' only tie with Europe, Canada's francophones having been abandoned by France centuries earlier. In his lengthy discourse, Veniot recalled important events in Acadian history, a history, he stated, which was marked by persecution, expulsion, and suffering. Acadians, he said, were opposed to further coercion in the form of conscription for overseas service unless they could be convinced of the absolute necessity of such extreme measures. During the last war, he continued, Acadians did their part voluntarily, and, while they did oppose conscription, that was due to the measures being unfairly applied. Like anglophones, Acadians believed in defeating the enemy before it reached Canada and, "nous sommes prêts à donner librement nos vies jusqu’à la limite de notre capital humain et de nos faibles ressources. Toutefois nous ne voulons plus voir

\footnotetext{
175 “No Vote Pamphlets Appear at Moncton," Daily Gleaner, 27 April 1942, 7.

176 See "Hon. J.E. Michaud Urges Yes Vote," Daily Gleaner, 20 April 1942, 4; "Gloucester County Organizes for Yes,” Daily Gleaner, 23 April 1942, 9.
} 
pourchasser nos jeunes gens comme des bêtes sauvages sur nos collines et dans nos forêts à coups de fusil et à la pointe de la baionnette." Acadians, Veniot maintained, were not slackers and the government should give them a chance by creating more francophone units and training centres and training francophone officers to command them. ${ }^{177}$

Veniot asserted that raising an army for service overseas was only part of a total war effort and that volunteerism as well as conscription were means to this end. He did, however, question the efficacy of conscription, largely because its application in 1917 had dangerous racial undertones, emphasizing "encore une fois que la conscription est maintenant et sera toujours au Canada une question de race.” He continued, "chaque Canadiens sait, au fond de lui-même, que la conscription; au-jourd'hui plus que jamais, contient en germe la lute, la division, la résistance par la force, et peut-être même l'effusion du sang, comme dans la dernière guerre. Nous ne gagnerons jamais la guerre tant que nous serons divisés par une question de race...."178 It was clear that the Acadians and their leaders feared that the persecution and bloodshed of 1917 would be repeated if such measures were to be imposed in the present war. Conscriptionists, Veniot stated, were concerned with equality of sacrifice, however, equality of sacrifice necessitated equality of rights. And those equal rights for the three-quarters of a million francophones outside Quebec, who had been refused the right to have separate schools for the education of their children in their first language, were nowhere to be found. Little wonder the Acadian newspapers, which had been advocating for improved French-language education for decades, were so approving of Veniot's message. ${ }^{179}$ Nevertheless, he would

177 "Discours Veniot: La conscription une question de race," Le Madawaska, le 19 février 1942, 5. 178 "Discours Veniot: La conscription une question de race," Le Madawaska, le 19 février 1942, 5. 179 “Discours Veniot: La conscription une question de race," Le Madawaska, le 19 février 1942, 11. 
be voting yes in the plebiscite and urged his constituents to do the same. He was not supportive of conscription, but he believed that, if conscription ever became necessary, Mackenzie King would be more likely to implement it in a fair and equitable fashion than the Conservatives, recalling "la manière odieuse dont ils l'ont appliquée aux gens de Québec pendant la dernière guerre.”180

While the Acadian newspapers wholeheartedly approved of Veniot's speech, R.B. Hanson did not. He was particularly opposed to the passage of Veniot's speech which stated that obligatory military service in Canada was a question of race and he declared the speech to be one of the most dangerous that he had heard during his time as a member of the House. Hanson stated his belief that Acadians would have readily accepted obligatory service if their MPs had properly prepared them. Hanson's words provoked an angry editorial in La Voix d'Évangéline, declaring that it was not the job of federal representatives to prepare their people to accept conscription. The editor reminded readers that, during the 1940 election, the leaders of both parties had declared themselves to be against conscription. Nor was Veniot the first to suggest that conscription had racial undertones, as Manion had repeated in speeches throughout the election campaign that conscription in the last war had caused significant disharmony and "violent racial antagonisms." ${ }^{181}$ The paper believed that the Acadians did not have any lessons to learn from the leader of the Conservative Party. Curiously, neither the Daily Gleaner nor any

\footnotetext{
180 "Discours Veniot: La conscription une question de race," Le Madawaska, le 19 février 1942, 12, 15. Parts of Veniot's speech also appeared in La Voix d'Évangéline on 19 and 26 February, and on 5 March. 181 “M. Veniot et M. Hanson," La Voix d'Évangéline, le 5 mars 1942, 3.
} 
other anglophone New Brunswick newspaper believed the issue was of enough importance to print either Veniot's speech or Hanson's reply. ${ }^{182}$

The racial undertones in House of Commons speeches did not end with Veniot and Hanson. In his speech two days later, Kent MP Aurel Léger also saw racial aspects in the debates over conscription and the plebiscite. Léger explained that recent reports indicated that the army already had all the recruits it was capable of training. Therefore, the push for conscription could have only one purpose, "celui de désunir les deux races les plus importantes du pays. Ces gens savent que les habitants de langue français sont en general contre la conscription.... Ce n'es pas parce qu'ils ne veulent pas assumer leur part d'obligations, non, c'est parce qu'ils croient que c'est plus honorable de faire leur part librement." Léger believed that French Canadians, Acadians included, were already doing their part by enlisting voluntarily, claiming that, in New Brunswick, Acadians made up a third of the population yet comprised 40 to 45 percent of enlistments. Léger's claims about Acadian enlistments, while overstated, served to prove his point that many French Canadians were voluntarily doing their part. Yet, despite his fears of division along racial lines as a result of conscription, Léger stated that it was the duty of elected representatives to support the Government's attempt to relieve itself of its pledge. He acknowledged that his constituents, four-fifths of whom were Acadian, did not want conscription, but claimed that the discord was the result of the capitalist-controlled press, which was seeking to create discord in order to take power and make money from the war effort. Implying that a yes vote was a vote of confidence in Mackenzie King, Léger

\footnotetext{
${ }^{182}$ My reading of the Daily Gleaner did not turn up any mention of either Veniot's speech or Hanson's reply. Cormier states that none of the other New Brunswick anglophone papers reported on the issue; Cormier, Acadiens et la Seconde Guerre, 39.
} 
suggested that a vote against the Prime Minister would bring the opposition into power.

They, most certainly, would impose the same measures as they had in the first war. ${ }^{183}$

Like his Liberal colleagues, Restigouche-Madawaska MP and sole Acadian

Cabinet Minister J.E. Michaud urged his constituents to vote yes during a public meeting on the plebiscite held at the Edmundston Courthouse. ${ }^{184}$ Michaud said that, in light of recent changing circumstances and new information to which he had access as a member of the Cabinet War Committee, it was his duty to inform voters that the government should be released of all restrictions on its freedom of action in pursuing the war effort. While Michaud admitted that the government could have overturned the restrictions placed on it without resorting to a plebiscite, to do so would have been to act in the same manner as the dictators who Canada was trying to defeat. In an effort to maintain the country's democratic character, the issue was being brought before the people. Michaud explained that the government's promises had been made in 1940 when the war was limited to Europe. It was, however, no longer a European war but one that threatened all countries, and the government was asking to be relieved of its promises because it believed such measures were absolutely necessary for the defence of Canada and for the defeat of Germany. Michaud reminded voters that a yes vote did not necessarily mean that the government would impose conscription for overseas service but merely that they

\footnotetext{
183 "Les Acadiens du Nouveau-Brunswick ont fourni leur part de volontaires," La Voix d'Évangéline, le 5 mars 1942, 10.

${ }^{184}$ Michaud served as Minister of Fisheries from 23 October 1935 to 5 October 1942. From 27 November 1941 to 9 December 1941, he was Acting Minister of Justice and Attorney General of Canada and as such would have had access to privileged information of the Cabinet War Committee. He would later serve as Acting Minister of Public Works from 13 May 1942 to 6 October 1942 and as Minister of Transport from 6 October 1942 to 17 April 1945. He was the sole Acadian Cabinet Minister during this period. See "Hon. Joseph Énoïl Michaud, P.C., M.P.,” in Parliament of Canada Biography, accessed May 10, 2019, https://lop.parl.ca/sites/ParlInfo/default/en_CA/People/Profile?personId=15312.
} 
would have the moral authority to do so in dire circumstances. ${ }^{185}$ The article was accompanied by a letter from Michaud to the electors of Restigouche-Madawaska in which he strongly encouraged them to vote yes. ${ }^{186}$

The Acadian newspapers did not confine themselves to reporting the opinions of local MPs. On 5 March, La Voix d'Évangéline printed Mackenzie King's reply to a question from Hanson regarding the policy that he intended to implement following the plebiscite. According to King, the government "ne prendra une decision sur la conscription pour service outre-mer que lorsque le besoin s'en fera sentir.... La conscription pour service outre-mer 'n'est pas necessaire et il se peut qu'elle ne soit jamais nécessaire'."187 Le Madawaska published excerpts from one of King’s radio broadcasts in which he reassured the public that the plebiscite was not being held to ask the people whether they felt conscription for overseas service should or should not be adopted. He emphasized that the sole purpose of the plebiscite was to ask the people whether they saw fit to relieve the government of its prior promises, which would allow the government to conduct the war effort as it saw fit and to adopt the most appropriate strategies as the situation evolved. ${ }^{188}$

For many francophones, the plebiscite nevertheless resulted in fear that the government intended to impose conscription for overseas service, despite the assurances of the various MPs and the Prime Minister himself. Quebec francophones quickly organized a vocal campaign for a no vote under the auspices of la Ligue pour la défense

\footnotetext{
185 “L'honorable Michaud demande à tous de dire 'oui' au plebiscite," Le Madawaska, le 16 avril 1942, 1, 8.

186 “Aux electeurs de Restigouche-Madawaska," Le Madawaska, le 16 avril 1942, 9.

187 "La conscription n'est pas necessaire et il se peut qu'elle ne le soit jamais," La Voix d'Évangéline, le 5 mars 1942, 1.

188 “M. King dit pourquoi nous aurons un plebiscite," Le Madawaska, le 9 avril 1942, 1, 7.
} 
du Canada. Opposed even to the idea of holding a plebiscite, they rejected the validity of such a measure as they believed the majority should not be able to erase the promise a government had made to a minority. ${ }^{189}$ Through the distribution of leaflets, open letters to other newspapers, radio broadcasts, and public rallies, the Ligue campaigned for a no vote. Chapters of the Ligue were founded in almost all major population centres of Quebec and were supported by Le Devoir, the only francophone daily newspaper which sided definitively with the no campaign. Unable to broadcast its message on the CBC as use of national radio was reserved for political parties, and hence the yes campaign, the Ligue was forced to pay for airtime at independent radio stations in Quebec. ${ }^{190}$ One station, located at New Carlisle, which frequently broadcast anti-conscriptionist speakers, was also followed by Acadians in the Maritimes. Doucet believes this radio station likely influenced Acadian voters. ${ }^{191}$

While recognizing the right of all Canadians to vote in the plebiscite according to their conscience and judgement, the Ligue believed a no vote was necessary "parce que nul ne demande d'être relevé d'un engagement s'il n'a déjà la tentation de le violer, et parce que, de toutes les promesses qu'il a faites au peuple du Canada, il n'en reste qu'une que King voudrait n'être plus oblige de tenir; la promesse de ne pas conscrire les hommes pour outre-mer." 192 Proponents of the Ligue believed that, if Canada was threatened to the extent which the politicians claimed, the first duty of Canadians should be towards the defence of their own country. The Ligue doubted the necessity of conscription in the near

\footnotetext{
${ }^{189}$ Laurendeau, Crise de la conscription, 74.

${ }^{190}$ Laurendeau, Crise de la conscription, 83, 104-8.

191 Doucet, "Politics," 258.

${ }^{192}$ Laurendeau, Crise de la conscription, 84.
} 
future; by the government's own accounts, the voluntary system was still providing the required numbers of men. ${ }^{193}$

In Acadian regions of New Brunswick, the Ligue's message also found support and was largely promulgated through local chapters of the Ordre de Jacques-Cartier although, the no campaign in New Brunswick was much more subtle than that of Quebec. One circular from OJC headquarters in Ottawa which appeared in New Brunswick contained an order for members, "RÉPONDRE NON AU PLÉBISCITE ... ce devrait être la réponse de tous les véritables Canadiens.... il est entendu que l'acceptation de ce mot d'ordre se fera sans discussion...." Members were encouraged to exercise their influence, especially with non-francophones, using leaflets, newspapers, and public speeches to encourage as many negative votes as possible. ${ }^{194}$ The historian Cormier believes that the appearance of leaflets written by the Ligue in Moncton and other parts of the province just prior to the plebiscite is evidence that some New Brunswick members followed the OJC order. ${ }^{195}$

Further evidence taken from meeting minutes of another New Brunswick chapter of the OJC lends weight to Cormier's argument. On 27 March 1942, the Edmundston chapter of the OJC proposed “qu'une somme n'excédent pas $\$ 20.00$ soit dépensé pour l'impression de pas plus de 10,000 copies du manifeste sur le plébiscite pour distribution dans toutes les paroisses du compté. On prie le secretaire d'avertir les autres XC

\footnotetext{
${ }^{193}$ Laurendeau, Crise de la conscription, 83-86. The Ligue was largely the creation of l'Ordre de Jacques Cartier, a secret francophone society dedicated to the advancement of francophone causes. André Laurendeau, the secretary of the Ligue was an influential member of the OJC. Members of the OJC were frequently educated and influential members of their communities.

${ }^{194}$ Centre d'études acadiennes Anselme-Chiasson, Fonds 30 Théophile-Godin, Chemise 30.2-3, Ordre de Jacques-Cartier circulaire ${ }^{\circ} 415$ du Secrétariat national à Ottawa, le 21 mars 1942.

${ }^{195}$ Cormier, Acadiens et la Seconde Guerre, 43.
} 
[commanderies] de la province à ce sujet." ${ }^{196}$ At the next meeting, 17 April, one member reported that Le Madawaska had refused to print the manifesto. However, another member showed the group an assortment of pamphlets published by the Ligue pour la défense du Canada. The meeting minutes report that they decided to telegraph Montreal to obtain ten thousand of the pamphlets, while the rest of the meeting was spent discussing how to distribute them. ${ }^{197}$ No mention was made at later meetings of whether the pamphlets were obtained or distributed, but, the previously mentioned sudden appearance of the leaflets around New Brunswick suggests that the Edmundston chapter, or one of the others, managed to obtain and distribute large quantities of pamphlets encouraging a no vote to francophones and anglophones alike.

While New Brunswick branches of the OJC were advocating for a no vote, the position of the francophone newspapers was less clear. Both La Voix d'Évangéline and Le Madawaska adopted an editorially neutral stance, encouraging readers to consider both sides and to vote yes or no according to one's conscience. In addition to the neutral editorials encouraging citizens to educate themselves and vote, both newspapers printed a wide variety of speeches and articles which encouraged a yes vote, as mentioned earlier in this chapter. However, unlike the anglophone papers, the Acadian papers did not ignore the opposition. La Voix d'Évangéline printed the manifesto of the Ligue pour la défense du Canada two weeks prior to the plebiscite. ${ }^{198}$ Le Madawaska, which had declined to print copies of the manifesto for the OJC, also declined to publish it for its

\footnotetext{
${ }^{196}$ Centre d'études acadiennes Anselme-Chiasson, Fonds 1165 Ordre Jacques-Cartier - cellule FrançoisCiquart Edmundston. Procès-verbal, le 27 mars 1942.

${ }^{197}$ Centre d'études acadiennes Anselme-Chiasson, Fonds 1165 Ordre Jacques-Cartier - cellule FrançoisCiquart Edmundston. Procès-verbal, le 17 avril 1942.

198 "Manifeste - La Ligue pour la défense du Canada," La Voix d'Évangéline, le 16 avril 1942, 7.
} 
readers, instead electing to include an editorial from the Quebec paper L'Action

Catholique, which explained various reasons why the editorial staff of that paper was opposed to conscription and advocating for a no vote in the plebiscite. Given that the Prime Minister himself had previously stated that conscription was one of the greatest causes of division between the races within Canada, the editorialists stated that, by declining to release the government from its pledge, voters would be protecting "contre une clique de gens pour lesquels notre effort de guerre n'est rien sans la conscription, et qui immoleraient volontiers le Canada sur l'autel de 1'Empire."199

Given the opposition to conscription among New Brunswick Acadians which would become apparent after the plebiscite, why was the no campaign in the province so subtle compared to that of Quebec? Cormier suggests that this is because of the unique situation faced by the New Brunswick Acadians as a minority people with little political influence and fearing reprisals by the anglophone majority. ${ }^{200}$ This conclusion seems logical. As chapter one illustrated, the Acadians had historically felt suppressed, politically, socially, and economically.

Press censorship, or self-censorship, also likely played a role in reducing the number of no vote related articles in the francophone newspapers. During the war, censors did not review individual news stories. Instead journalists self-censored by comparing their work to the published restrictions and consulted the censors if they had concerns about their own work. ${ }^{201}$ Censorship was intended to prevent the enemy from

\footnotetext{
199 “Action Catholique: Pourquoi nous sommes contre la conscription,” Le Madawaska, le 12 mars $1942,3$. ${ }^{200}$ Cormier, Acadiens et la Seconde Guerre, 42.

201 Timothy Balzer, The Information Front: The Canadian Army and News Management during the Second World War (Vancouver: UBC Press, 2011), 5. With harsh penalties imposed on newspapers that printed articles which were deemed to be undermining Canada's war effort, most papers chose to self-censor.
} 
gaining access to useful information, but the censorship regulations also effectively gave the government, censors, and even the public the ability to suppress a wide variety of dissent, or views which could potentially be construed as dissent, as well as those deemed harmful to morale or recruitment. ${ }^{202}$ While officially citizens were to vote according to their conscience in the plebiscite, numerous advertisements and statements by the anglophone press and some anglophone politicians implied that French Canadians were voting no in attempt to avoid doing their fair share for the war effort. More ominously, they implied that, if Hitler were to vote in the plebiscite, he would vote no. ${ }^{203}$ It is possible that some French-language publications, especially those in areas where francophones were a minority, might have deliberately avoided printing material associated with the no vote out of fear of being accused of opposing the war effort.

Differing opinions within the various strata of Acadian society concerning the plebiscite and conscription itself also influenced the article choices in the newspapers. On some significant occasions, as will soon become apparent, the views of the Acadian elites and politicians differed from those of the people. All three of the Acadian MPs, for example, were calling for a yes vote in the plebiscite, while, during the First World War, many Acadian elites and some politicians had supported conscription and the Union government. ${ }^{204}$ According to Frances Henry and Carol Tator, newspapers reflect the views of their owners. ${ }^{205}$ While it is impossible precisely to ascertain the views of the owners of La Voix d'Évangéline and Le Madawaska, there are a few clues which allow

\footnotetext{
202 Jeffrey Keshen, Saints, Sinners, and Soldiers: Canada's Second World War (Vancouver: UBC Press, 2004), 17.

${ }^{203}$ Laurendeau, Crise de la conscription, 75-78.

204 Theobald, Bitter Harvest, 64-68.

${ }^{205}$ Frances Henry and Carol Tator, Discourses of Domination: Racial Bias in the Canadian EnglishLanguage Press (Toronto: University of Toronto Press, 2002), 7.
} 
for some generalized conclusions. Both papers were heavily influenced by the Catholic Church, which was officially promoting a yes vote. ${ }^{206}$ Newspaper ownership was by and large the purview of the local elites, many of whom had been supportive of conscription in the past. During the previous war, an anti-conscription editorial published in L'Évangéline was followed in the next edition by a rebuttal by the paper's Board of Directors, which stated that the views expressed by the editor did not reflect the views of the paper itself. ${ }^{207}$ It is probable that the views of the newspapers' directors and major influencers affected the papers' printing choices in the Second World War.

On 27 April, the flurry of last-minute speeches and organizing came to an end as citizens went to the polls. While the voter turnout was high in Ontario and Quebec, in the Maritimes it was reported to be lower than in the last federal election. ${ }^{208}$ A Canadian Press article in the Daily Gleaner cheerfully reported that three-quarters of Maritimers who voted were in favour of releasing the government from its pledge. "Fine majorities" prevailed in most constituencies: "only Kent, Gloucester and Restigouche-Madawaska, all in northern New Brunswick near the Quebec border, returned a 'no' majority and it was snowed under by huge 'yes' margins rolled up in the central and southern sections of the province." ${ }^{209}$ Nevertheless, 69 percent of New Brunswickers had voted yes, the

\footnotetext{
${ }^{206}$ Byers, Zombie Army, 107. While the French-language papers contained numerous articles and editorials which explained how Hitler and Nazism were anathema to Catholicism, they did not contain any articles in which the Acadian clergy expressed their views on the plebiscite or conscription.

207 “Abus et consequences," L'Évangéline, le 28 novembre 1917, 1; "En marge d'une letter de M. Robidoux," L'Évangéline, le 5 decembre 1917, 1. La Voix d'Évangéline was known as L'Évangéline until 1937 and again from 1944 until it's closure in 1982.

${ }^{208}$ However, Nugent points out that this decline in voting rates was significantly less in ridings with greater Acadian populations. Nugent, "The Acadian Response," 78.

209 "The Great Bulk of the Maritime Provinces' Electorate Stood Today in the 'Yes' Column," Daily

Gleaner, 28 April 1942, 1. The other five constituencies were Prescott and Russell, Ontario and Provencher, Manitoba, all which had large francophone populations, as well as Vegreville, Alberta and Rosthern, Saskatchewan which had large German and Ukrainian populations.
} 
smallest yes vote outside of Quebec, where 73 percent of electors had voted no. The constituencies of Gloucester, Kent, and Restigouche-Madawaska were three of only eight constituencies outside of Quebec to return a no vote. ${ }^{210}$

As it had prior to the plebiscite, the Daily Gleaner paid little further attention to the no vote by New Brunswick francophones, instead focusing its attention upon the overall implications of the results and upon areas which polled a yes vote. One article from an Ottawa source anticipated the adoption of conscription in the near future, although perhaps not immediately, as a result of the "overwhelming popular demand latent in yesterday's voting, though conscription was not a direct issue." Putting its faith in a part of Mackenzie King's post-plebiscite statement which indicated that the majority must prevail, the author decreed that the negative Quebec vote would not stand in the way and, now that King was concerned about winning a war, not an election, he would "take any measure necessary for victory." 211 While no statement from Conservative Leader and local MP Hanson was forthcoming, the paper reported that he was pleased by the outcome, stating "the government has a clear road now to go ahead." 212 On the results in its own riding, the Daily Gleaner reported that "York-Sunbury as a whole kept in step with English-speaking Canada" as voters "trekked to the poles in a steady stream to turn in a smashing 'Yes' vote." ${ }^{213}$ With only 3 polls out of 117 returning a no vote, the massive affirmative majority demonstrated the overwhelming commitment of local voters to releasing the government from its pledge.

\footnotetext{
${ }^{210}$ Granatstein and Hitsman, Broken Promises, 171.

211 “Conscription for Overseas Within Next Few Months Seen,” Daily Gleaner, 28 April 1942, 9.

212 “Opposition Leader Gratified at Vote," Daily Gleaner, 28 April 1942, 9.

213 "Fredericton Had Heavy Vote Monday in the Plebiscite," Daily Gleaner, 28 April 1942, 12.
} 
The paper published the plebiscite returns by province and constituency for Eastern Canada and by county and community for parts of New Brunswick, showing that the results varied at the community and polling station level even within constituencies which had returned large yes or no majorities. For example, while overall RestigoucheMadawaska returned a no majority, the results were very different in the two counties which made up the riding. Eighty-two percent of Madawaskans had voted no, while in Restigouche county, only twenty-three of sixty-five polls returned a negative vote. ${ }^{214}$ No explanation was provided for this, but Restigouche was a much more linguistically mixed county, with greater numbers of anglophones, than other areas of the North Shore. Restigouche also had significantly fewer unilingual francophones than Madawaska. In Restigouche, 37 percent of francophone males were unilingual, as compared to 69 percent in Madawaska. ${ }^{215}$ The Daily Gleaner also reported that, while Gloucester overall had voted no, Bathurst had voted yes at a ratio of four to one. The author reported that Bathurst citizens had conducted a strong campaign for a yes vote and speculated that, if this level of organization had been present throughout the county, an affirmative vote in Gloucester would have been obtained. Yet this would have been unlikely because the non-urban areas of the county were more francophone and the article admitted that, despite the overall outcome, the number of voters in rural areas was low due to roads being closed. ${ }^{216}$ In addition, French Canadians were not easily swayed even by their own

\footnotetext{
${ }^{214}$ Cormier, Acadiens et la Seconde Guerre, 45. "Restigouche County Strong Yes Majority," Daily Gleaner, 30 April 1942, 9.

${ }^{215}$ Cormier, Acadiens et la Seconde Guerre, 63.

216 "Bathurst Gave Affirmative Vote," Daily Gleaner, 28 April 1942, 9. This article seems to suggest that voters in rural Gloucester had trouble getting to the polls. Roads in this part of the province were notoriously poor and the spring thaw had likely made them impassible in certain areas.
} 
MPs' urging of a yes vote. Attempts by Michaud, Veniot and Léger to bring about a yes vote in their home constituencies were overwhelmingly rejected by voters.

The Acadian papers responded to the plebiscite results a bit more warily. Le Madawaska reported that, according to reports from the different provinces, French Canadians across the country had voted as a bloc. A detailed breakdown of the results in Madawaska county showed a solid no vote. Edmundston was the only Madawaska community where the yes vote was of any significance, and, even there, a negative response still came out on top by 283 votes. ${ }^{217}$ The paper had little to say about the overall result. However, it did publish an editorial by L'Action Catholique, which expressed French Canadians' concerns over what could happen next given the affirmative result. The editor feared that the result had provided the conscriptionists with a new approach and that the conscriptionist press was simply biding its time, waiting for the Prime Minister to state his position before launching a vociferous campaign for overseas conscription. The whispers were starting, they claimed, that King would not impose conscription because Quebec had voted no, despite the will of the majority being in favour. The country was facing a potential crisis, the editorial concluded, the same issue which had threatened Canadian unity in the First World War was poised to do so once again. $^{218}$

La Voix d'Évangéline was a bit more willing to express its own opinion on the plebiscite results. In the first editorial following the plebiscite, the paper urged the government to proceed with caution in making changes to its pursuit of the war, because the francophone electorate had declined to release King from one of the most

217 “Le gouvernement releve de ses promesses par le plébiscite,” Le Madawaska, le 30 avril 1942, 1.

218 “Quelles mesures?” Le Madawaska, le 7 mai 1942, 3. 
fundamental points of his war programme, and it was from francophone electors that the government normally drew a large part of its support. While francophone opinion differed from the majority, the editorial emphasized that this did not mean they opposed the war effort, taking for example "les Acadiens du Nouveau-Brunswick ... qui on en majorité répondu 'Non', n'en on pas moins fourni à l'armée de terre un nombre imposant de volontaires. En fait, ils on répondu à l'appel de l'Etat de façon magnifique." ${ }^{219}$ The editor hypothesized that Acadians had declined to release the government from its pledge because the government had not convinced them that conscription might actually become necessary. Articles in the weeks and months leading up to the plebiscite indicated that the voluntary system was working. Despite this, the editorial concluded, Acadians were good Canadians and would do their duty. ${ }^{220}$ The paper made sure to communicate that, despite their rejection of conscription, Acadians continued to support the war effort. On subsequent pages, articles about French Canadian loyalty to the British Empire and the plebiscite results in Acadian communities were printed side by side. ${ }^{221}$

Scholars have ascribed various meanings to the plebiscite results and have attempted to explain Acadian attitudes in various ways. The majority of these assessments, however, focus on the experiences of Acadians in all three Maritime provinces, rather than concentrating specifically on New Brunswick. Cormier reports that, even though the plebiscite officially sought only to provide the government with the moral authority to resort to conscription for overseas service, Acadians, like the Québécois, believed that the government already intended to implement conscription. ${ }^{222}$

\footnotetext{
219 “Le plébiscite," La Voix d'Évangéline, le 30 avril 1942, 3.

220 "Le plébiscite," La Voix d'Évangéline, le 30 avril 1942, 3.

221 “La loyauté canadien-canadienne-française," La Voix d'Évangéline, le 30 avril 1942, 7.

222 Cormier, Acadiens et la Seconde Guerre, 45.
} 
McClelland-Nugent questioned the strength of the Acadian no vote, concluding that, while Acadians were more opposed to conscription than anglophone Maritimers, they were less opposed than Quebec. The example of Gloucester is emphasized as it had a much lower no vote than other ridings with similar francophone populations. She suggests that assimilation, a history of cooperation with anglophones, pride in enlistment, and the Acadian history of neutrality or passivity played a role in their acceptance of conscription. Opposition to conscription, especially in New Brunswick, which McClelland-Nugent admits was higher than in the rest of the Maritimes, was attributed to greater ties to Quebec, a reluctance of francophones to serve in a largely anglophone military, and the belief that voluntary enlistment produced better soldiers and could provide the numbers needed. ${ }^{223}$ She suggests that the lack of overt opposition may be the result of Acadians greater respect for authority or docility as a result of numerical inferiority. Her thesis concludes that the plebiscite vote and speeches of New Brunswick MPs in the House indicate Acadian opposition to conscription, while high rates of enlistment, the MPs' support of the government position, and the lack of documented anti-conscription activity suggest an acceptance of government policies. ${ }^{224}$

Undoubtedly, the most vocal opposition and greatest negative vote was found in Quebec, yet the findings of this study do not entirely concur with those of McClellandNugent. While New Brunswick's Acadians were more opposed to conscription than their anglophone neighbours and less opposed to the war than the Québécois, an affirmative vote in the plebiscite by some Acadians did not necessarily signal support for conscription. During the campaign for a yes vote, the Acadian MPs were adamant that the

${ }^{223}$ Nugent, "The Acadian Response," 98-106.

${ }^{224}$ Nugent, "The Acadian Response," 108, 112-3. 
vote was simply about providing the government with the moral freedom to implement conscription if the need arose. They cautioned voters that a no vote could bring about a Conservative takeover of the government and the immediate imposition of conscription. Given the public nature of the yes campaign and the relatively quiet no campaign, it is likely that a number of Acadian voters were convinced that their MPs were telling the truth. The possibility of conscription was less threatening for francophones than its implementation by the Conservatives. Although there was a greater exchange of ideas between Quebec francophones and New Brunswick Acadians due to geographic proximity, the evidence from La Voix d'Évangéline and Le Madawaska does not support the hypothesis that anti-English war arguments held greater sway with the North Shore Acadians. Acadian opposition to conscription was much less vocal than that of Quebec, but this does not prove that Acadians supported conscription. It might simply suggest that they were cautious about expressing opinions that differed from those of the majority, who were often their neighbours, employers, and colleagues.

In her undergraduate thesis on the plebiscite and New Brunswick Acadian identity, Patricia Thibodeau describes the plebiscite campaign as characterized by detachment in terms of the newspapers, the federal representatives, and the people. The newspapers attempted to remain detached from the politics of the plebiscite, publishing paid material by both sides, but restricting themselves to neutral editorials which encouraged citizens to use reason when examining both sides of the issue and urged them to vote. After the plebiscite, however, both La Voix d'Évangéline and Le Madawaska occasionally published editorials which opposed conscription. ${ }^{225}$ Acadian politicians,

${ }^{225}$ Thibodeau, "Identity as Highlighted by Conscription," 72. 
Thibodeau concludes, feared igniting racial and linguistic discord in the province; despite their opposition to conscription, they supported a yes vote in the plebiscite. Acadian politicians reflected the views of the elites and not those of the people. ${ }^{226}$ She believes that the Acadian response to the plebiscite, in opposition to the position advocated by their own MPs and anglophone neighbours, symbolized the establishment of an Acadian collective identity and had a direct impact on the Acadian movements for economic, educational, and political reform after the war. ${ }^{227}$ While Thibodeau's conclusions on the nature of the opposition to the plebiscite in Quebec and New Brunswick are valid, her findings concerning Acadian identity do not entirely agree with those of this study. Evidence of a distinctive Acadian identity can be traced back many years prior to the plebiscite, prior even to the expulsion, as indicated in the previous chapter, and the identity grew stronger with time. While the New Brunswick Acadians did not have a strong political leader willing and able to communicate their views in Parliament, there were leaders emerging in other areas, such as education, prior to the Second World War. While Acadian success in bringing about educational, economic, and political reforms in the post-war years can be partially attributed to the government being forced to take note of the francophone minority, this is a result of increased efforts by Acadians over many years rather than a consequence of the plebiscite vote.

In New Brunswick, the demographic distribution of the Acadian population resulted in a significant negative vote in the constituencies where Acadians were most numerous, an occurrence which was not repeated to the same degree in the rest of the Maritimes. The Acadian populations of Nova Scotia and Prince Edward Island were

${ }^{226}$ Thibodeau, "Identity as Highlighted by Conscription," 55-59.

${ }^{227}$ Thibodeau, "Identity as Highlighted by Conscription," 74-76. 
much smaller and more scattered than that of New Brunswick. The Nova Scotia ridings with larger Acadian populations did report a larger negative vote than other ridings in that province; however, this Acadian vote was not large enough to change the overall affirmative result in these ridings. The results of the plebiscite demonstrate that most Acadians disregarded the counsel of their MPs and voted according to their conscience. This response was based on their belief that one could be both anti-conscriptionist and supportive of the war effort at the same time. Acadian opposition to conscription was less publicly visible than that of Quebec and seems largely confined to a few newspaper articles and to the plebiscite vote itself. This is largely a result of the Acadians' position as a francophone minority in an anglophone province which was largely supportive of conscription. History taught the Acadians to express opposition and dissent cautiously lest it bring about the wrath of the majority; in 1942, there was no issue which aroused stronger sentiment than that of conscription. 


\section{Chapter Three}

\section{The Second Conscription Crisis}

The first conscription crisis did not end with the tabulation of the plebiscite

results. Although the plebiscite granted King the moral authority to impose conscription for overseas service, French Canada's near total opposition made him uneasy. He was determined to do everything possible to prevent conscription from becoming necessary, believing that national unity depended upon it. In the spring of 1942, conscription was certainly not a necessity as the vast majority of the army overseas had yet to see action. The plebiscite, however, had brought the conscription issue to the forefront and something would need to be done to satisfy English Canadians, some of whom believed the plebiscite result signaled the immediate imposition of conscription. ${ }^{228}$

Even within Cabinet, there was debate over how to amend Section 3 of the National Resources Mobilization Act, which limited the use of conscripts to within Canada and its territorial waters. ${ }^{229}$ King himself favoured repealing Section 3 and extending the use of conscripts to all of North America, a move, he felt, that would satisfy those clamouring for government action in the wake of the plebiscite. King resolved to continue to oppose the use of conscription for its own sake, but remained

\footnotetext{
${ }^{228}$ Granatstein and Hitsman, Broken Promises, 171-2. Granatstein and Hitsman cite a 1942 poll from Public Opinion Quarterly which was taken after the plebiscite. Among anglophone Canadians surveyed, 54 percent believed that the vote had simply been about freeing the government from its promise while 42 percent believed that it signaled immediate adoption of conscription for overseas service.

${ }^{229}$ Minister of National Defence J.L. Ralston and Minister of National Defence for Naval Services Angus Macdonald favoured elimination of Section 3, while Justice Minister Louis St. Laurent maintained that eliminating the geographic restriction would necessitate the immediate imposition of overseas conscription. King also wanted to return to Parliament in the event that conscription for overseas service was to be enforced, but some ministers argued that this would cause unnecessary delay at a time when reinforcements were needed and that Cabinet ought to pass an order-in-council if conscription needed to be implemented.
} 
willing to reconsider the matter if the voluntary system failed to provide sufficient reinforcements at some future date. ${ }^{230}$

On 11 May 1942, King introduced the bill to amend the NRMA, and the New Brunswick newspapers closely followed the Parliamentary debate over Bill 80 in the following months. The papers avoided providing any judgement on the evolving conscription debate in Parliament, confining themselves to reporting the statements of the Prime Minister and the various members of the House who spoke during the debates. All seemed acutely aware of the implications of the debate, which, if not satisfactorily resolved, had the potential to cause further divisions between French and English Canadians and even to bring down the government.

The debate over Bill 80 was front page news in La Voix d'Évangéline throughout May and June. It reported that Cabinet was in agreement with the decision to amend Section 3, but that members differed on whether it was necessary to return to Parliament for authorization or whether conscription could merely be adopted by order-in-council at such time as the government decided the measure was necessary. ${ }^{231}$ Not all members were in agreement with the proposed amendment. The resignation of Minister of Public Works and Transport P.J.A. Cardin caused a stir. Cardin explained that he had given his word to his constituents and could not accept the government's policy; he was committed to fighting against conscription unless it could be demonstrated that such a measure was necessary and in the best interests of the country. ${ }^{232}$ This was in direct opposition to the position taken by Conservative leader R.B. Hanson, who claimed that the plebiscite

\footnotetext{
${ }^{230}$ Granatstein and Hitsman, Broken Promises, 172-9.

231 “Crise politique grave à Ottawa," La Voix d'Évangéline, le 14 mai 1942, 1, 6.

232 "Cardin continuera à siéger du côté ministériel avec les 11 députés dissidents du Québec," La Voix d'Évangéline, le 21 mai 1942, 1, 2.
} 
results constituted a mandate to impose conscription. Throughout the debate in the House of Commons, King maintained that conscription was not immediately necessary and that it might never become necessary if the voluntary system continued to produce sufficient numbers of men. He considered his policy of "not necessarily conscription, but conscription if necessary" to be a compromise between those who clamoured for its immediate imposition and those who rejected its use under any circumstances. ${ }^{233}$

While the papers largely remained neutral during the parliamentary debate, two editorials in Le Madawaska showed the paper to be in favour of King's policy of moderation and delay. The 4 June editorial by L.-P. Roy from L'Action Catholique explored the differences between what it termed the Imperialist and Canadianist mentalities present in the conscription debate. Hanson, the article stated, believed that Canada was at war to defend the British Empire. Conscription was a necessity. On the other hand, Joseph Thorson, the Minister of National War Services, believed that Canada had entered the war of its own accord and for its own defence and should use the most effective means to fight the war, which included voluntary recruitment as long as the system produced results. The editorial concluded that the government position on conscription was becoming more precise and there was hope "qu'elle sera anticonscriptionniste par canadianisme, alors que l'attitude des oppositionnistes sera conscriptionniste par impérialisme.”234

In the second editorial, Lucien Fortin explored some of the main points from King's speech to Parliament on 10 June. Like all true Canadians, he stated, King wanted

\footnotetext{
${ }^{233}$ House of Commons, Debates, 10 June 1942, 3236; and Granatstein and Hitsman, Broken Promises, 177. "La conscription non necessaire maintenant; l'avenir du Canada d'abord," Le Madawaska, 18 juin 1942, 5. ${ }^{234}$ Anticonscriptionniste par canadianisme," Le Madawaska, le 4 juin 1942, 3.
} 
a total war effort as the most effective way to aid the Allies; the difference was in how various groups sought to achieve this total war. Fortin accused "les partisans du groupe impérialiste" Hanson and Meighen of wanting immediate implementation of conscription, even if it was of no significant benefit to the war effort and damaging to national unity. For Mackenzie King, said Fortin, "la conscription ne doit pas être considéré comme une fin, mais comme un moyen de recrutement" and would only be utilized if it was absolutely necessary for the pursuit of victory. Importantly for Fortin, King was a firm believer in national unity and the voluntary system. He had always acted as a Canadian and sought to find a Canadian solution to national problems and "sur la question de conscription, M. King ne mène pas autrement la lute."235

The editors of La Voix d'Évangéline did not comment on the conscription debate in Parliament, choosing instead to call attention to Acadians' attempts to participate voluntarily, which had often been hampered by a lack of opportunity at the hands of the anglophone military establishment. While praising the military's decision to appoint French Canadian Major General P.-E. Leclerc to the command of $7^{\text {th }}$ Division, the editorial noted that "nos Canadiens de langue français ne fourniront jamais l'effort, tout l'effort dont ils sont capables tant qu'ils n'auront pas... le sentiment profond qu'ils sont dans cette aventure des partenaires égaux. Ils veulent participer à l'aventure avec tout ce qu'elle comporte de risques et d'avantages." ${ }^{236}$ It had taken over two years for the military to recognize the necessity of francophone officers and instructors for training francophone recruits. Worse still for the editor, despite having provided thousands of

\footnotetext{
235 "La conscription: Non une fin mais un moyen," Le Madawaska, le 18 juin 1942, 3. The $7^{\text {th }}$ Canadian Division was created for the purposes of home defence on 12 May 1942. Divisional headquarters were located in Debert, Nova Scotia. The division was disbanded on 15 October 1943. 236 “À propos de nominations récentes," La Voix d'Évangéline, le 28 mai 1942, 3.
} 
recruits to other units, Acadians were still lacking a unit with which they could identify and call their own. This argument was strikingly similar to that expressed by Gloucester MP Clarence Veniot in his speech in Parliament on 11 February, during which he advocated the formation of more francophone battalions commanded by francophone officers, upon which "le vieil esprit guerrier et chevaleresque français rendra alors manifeste à la nation et au monde que les Canadiens français ne sont pas des laches." ${ }^{237}$ Acadians were enlisting voluntarily and more would be likely do so if provided with the means to enable their full participation through the formation of an Acadian unit staffed by francophone officers and NCOs, a sentiment that would increase over the coming months.

Even though their constituents voted against releasing the government from its pledge concerning conscription in the plebiscite, the three New Brunswick Acadian MPs all supported Bill 80, although this support was given with much personal reflection on the matter. In his diary, Mackenzie King recorded that he spoke with Kent MP Aurel Léger, who was struggling to decide whether or not to support the bill. While initially in favour, Léger had apparently changed his mind after discussing the matter with some members of his constituency. According to King, "his feeling seemed to be that as we are pretty sure of a majority anyway he would be safer in his constituency if he voted against us." ${ }^{238}$ Léger evidently changed his mind once again after speaking with King. He voted with the government on 9 July.

Fisheries Minister J.E. Michaud seemed more certain of his views on the matter. Le Madawaska reported that "il considère l'adoption [de Bill 80] necessaire pour

237 “Discours Veniot: La conscription une question de race," Le Madawaska, le 19 février 1942, 12. ${ }^{238}$ Library and Archives Canada, Diaries of William Lyon Mackenzie King, 2 July 1942. 
accorder tous les pouvoirs au gouvernement en temps de guerre." He hoped there would never be a need to resort to conscription for overseas service and stressed that adoption of such measures would only help the war effort if implemented once the public realized "la gravité de la situation et combien il est necessaire de tout faire pour défendre notre pays...."239 As a cabinet minister, it would have been impossible for Michaud to vote against the bill; all the other ministers, including those from Quebec, had pledged their support.

Michaud's position was also affected by his personal beliefs on the matter. As indicated in the previous chapter, Michaud believed that King had no intention of imposing conscription immediately, and that he would wait to adopt the measure until such time as it proved necessary, if ever. Michaud also feared that, if the government were defeated on the conscription issue, the measure would most certainly be implemented in a much harsher manner under a Conservative government.

The House voted on the second reading of Bill 80 on 7 July, with the government winning a majority of 158-54. Forty-eight francophone and six CCF MPs voted against the bill, which was strongly supported by the Conservatives and anglophone Liberals, but only by a few francophones, including the three Acadian MPs. ${ }^{240}$ The bill passed its third and final reading in the House on 23 July with a vote of 141-45. Once again, most of the opponents were francophone. ${ }^{241}$ For French Canadians, the passage of Bill 80 was a symbolic event in that it marked the end of the debate over conscription. The pledges made to the French-Canadian minority at the start of the war had been repealed by the

\footnotetext{
239 “L'hon. Michaud a parlé en faveur de Bill 80," Le Madawaska, le 9 juillet 1942, 1.

${ }^{240}$ Granatstein and Hitsman, Broken Promises, 179.

241 “Unlimited Conscription Bill Given Third Reading, 141-45," Daily Gleaner, 24 July 1942, 3.
} 
expressed will of the anglophone majority. ${ }^{242}$ Conscription during the Second World War became another incident in a long series of events where the will of the anglophone majority was forced onto the francophone minority.

Bill 80 passed rather quietly into law in August 1942. Over the next year the government gradually extended the field of service of the NRMA troops to include all of the North America and the Caribbean, a move which aroused little public attention. ${ }^{243}$ Concern over conscription, which had received so much public attention over the preceding months, died down until well into 1944. Canadians were preoccupied with events overseas, and the economic and industrial war effort at home. The Victory Loan campaigns were front and centre in the local newspapers, which published numerous advertisements sponsored by the government and local businesses promoting the sale of bonds. Citizens were encouraged to invest every dollar possible to hasten victory. These ads even encouraged the investment of income not yet earned through the use of special payment plans. Provincial, as well as local, Victory Loan Committees were organized to coordinate the sale of subscriptions, and the parades, speeches, and other public events which accompanied the loan drives and encouraged participation through appeals to patriotic sentiment. Patriotism aside, citizens were reminded that the loan drives were a way to end the war more quickly and to invest in their post-war future, bonds paying better interest than most banks. ${ }^{244}$

Fierce competition developed between communities, schools, military units, and other organizations to see who could first reach and then surpass their quotas. At the end

\footnotetext{
242 Laurendeau, Crise de la conscription, 129; Granatstein and Hitsman, Broken Promises, 179.

243 Granatstein and Hitsman, Broken Promises, 197-8.

244 "Faisons le point," Le Madawaska, le 27 avril 1944, 3; LAC, RG 24-C-3, Vol. 17261, File 1252, Victory Loan, 6 May 1943.
} 
of the fourth Victory Loan campaign, Le Madawaska reported that No. 71 Canadian Army (Basic) Training Centre (CA(B)TC) had raised 370 percent of its objective, a record for training centres in Canada. ${ }^{245}$ The training centre war diary reported that, with 100 percent of personnel subscribed, the centre had set the Canadian record for personnel involved and amount subscribed combined, while No. 70 CA(B)TC in Fredericton had subscribed over $\$ 58,000$, the greatest amount for a single unit in the district. ${ }^{246}$ Both the newspapers and the war diaries of New Brunswick's two basic training centres reported regularly on the progress of Victory Loan campaigns.

As disposable income was being directed towards war financing and the voluntary forces and NRMA were expanding, wartime industry was also continuing to mobilize. The National Selective Service (NSS) was formed 24 March 1942 within the Department of Labour to assist with the allocation of manpower as between industry and the military. It was responsible for directing fit men away from non-essential industry towards war industry and enlistment and filling their positions with women or unfit men. While Granatstein and Hitsman state that the NSS "set in train a vast body of regulations and an increasing regimentation of all aspects of life," ${ }^{247}$ Stevenson concludes that the "NSS confronted strong, organized, and effective opposition from the general population [and other government agencies] that derailed or diluted many mobilization initiatives."248 Despite its inability to exert the intended level of control over human resources

\footnotetext{
245 “4ième emprunt de guerre," Le Madawaska, le 20 mai 1943, 1.

${ }^{246}$ LAC, RG 24-C-3, Vol. 17261, File 1252, Victory Loan, 13 May 1943.

${ }^{247}$ Granatstein and Hitsman, Broken Promises, 190.

${ }^{248}$ Michael D. Stevenson, Canada's Greatest Wartime Muddle: National Selective Service and the Mobilization of Human Resources during World War II (Montreal: McGill-Queen's University Press, 2001), 4 .
} 
mobilization, by October 1943, 1.1 million people were employed in essential war industries.

The shift towards war industry would have major implications for agriculture, which remained one of the dominant industries in New Brunswick, even though regulations enacted in 1942 prevented farmers and farm labourers from taking nonagricultural employment without the permission of an NSS officer. ${ }^{249}$ In early 1943 the papers began reporting that, due to a shortage of agricultural labour, essential agricultural workers should be encouraged to remain on the farms. These workers were eligible for special exemption from compulsory military service, but were permitted to enlist voluntarily. ${ }^{250}$ By the summer, the Departments of National Defence and Labour were cooperating with provincial agriculture departments in allowing farmers to hire soldiers as extra labour for the harvest. ${ }^{251}$ Nor was the labour shortage in primary industry confined to agriculture. In November 1943, Le Madawaska reported that 30,000 men were needed immediately to work in the woods if pulp and paper production was to keep up with wartime needs. Farmers were also being encouraged to work in the woods in winter to help alleviate this shortage. ${ }^{252}$

Throughout 1943 and early 1944, the expanding war effort was not the only issue on the minds of New Brunswick francophones. Disagreements between anglophones and francophones continued, as exemplified by concerns about political representation and language of education, both issues amplified by Acadians' minority status. An editorial in

\footnotetext{
${ }^{249}$ Stevenson, Canada's Greatest Wartime Muddle, 26-28.

250 "Eight-Point Programme to Keep Labor on the Farms," Daily Gleaner, 6 February 1943, 6.

251 "Soldats au service des cultivateurs," La Voix d'Évangéline, le 5 août 1943, 2; "Soldats sur les fermes au N.-B." La Voix d'Évangéline, le 2 septembre 1943, 2.

252 “Ont besoin de 30,000 hommes," Le Madawaska, le 11 novembre 1943, 1; "Manque d'hommes," Le Madawaska, le 18 novembre 1943, 4.
} 
La Voix d'Évangéline decried the injustice of not according the French-speaking counties fair and equitable representation in the legislature. In addition to the lack of representation, government promises to Acadians were often not kept. It was up to Acadian representatives, regardless of their number, to be the spokesmen of their people and to improve their lot. This had not been occurring, bemoaned the paper. Acadian representatives were too few in number and too inclined to vote along party lines. ${ }^{253}$ As discussed in the first chapter, for decades New Brunswick's Acadians had been fighting against a school system which claimed to provide a bilingual education, but which saw many francophone students leave school without adequate instruction in either French or English. The struggle for improved French-language education had not ended with the start of the war and it again became a prominent issue around the time of the campaign for an Acadian daily newspaper. For La Voix d'Évangéline, forcing students to study primarily in English from the very beginning of their education "tendent à nous asservir par l'assimilation." 254 While the language of instruction in schools might seem out of place in a discussion of experiences of the Second World War in New Brunswick, it was not out of place for the Acadians who noted the hypocrisy of the anglophone position. "Quel dommage," proclaimed the editorialist, "pour l'unité canadienne qu'il soit encore necessaire de lutter pour les droits minoritaires au Canada après trois-quarts de siècle de Confédération? Ne sommes-nous pas en guerre soi-disant parce que l'Allemagne a voulu imposer sa culture aux Slaves et aux Polonais?"255 This time,

253 "Un bloc acadien," La Voix d'Évangéline, le 23 septembre 1943, 3. The same could also be said about the federal Acadian MPs who had done little to obtain war contracts for their respective regions and who had voted to uphold Bill 80 despite their constituents having voted against releasing the government from its pledges not to implement overseas conscription in the plebiscite.

254 “À propos de bilinguisme scolaire," La Voix d'Évangéline, le 16 mars 1944, 5. 255 “À propos de bilinguisme scolaire," La Voix d'Évangéline, le 16 mars 1944, 3. 
however, some concessions appeared to have been won as the Education Minister C.H. Blakeny declared in a speech to the Association acadienne d'éducation that "you can not banish illiteracy from this province unless you give the child instruction in his mothertongue, at least in his formative years." ${ }^{256}$ Plans began to be put in place to improve education in Acadian areas, including the increased use of French as the primary language of instruction in the elementary grades.

Acadians were determined to improve their situation through education both in schools and through a daily newspaper. A paper that was both francophone and Catholic in its outlook was believed to have the power both to improve French-language skills and provide appropriate moral guidance. According to Léandre LeGresley, "sans lui, il serait inutile de parler de survivance, de prononcer d'éloquents discours pour réveiller le patriotism. C'est un aiguillon, autant qu'une arme de défense. Nous ne sommes qu'une minorité.... Le journal doit nous aider à garder notre mentalité proper, à faire face aux multiples dangers qui menacent notre âme nationale." ${ }^{257}$ A fundraising campaign was undertaken to found a Catholic, French-language newspaper for the Maritime provinces. By all indications, the Acadian population gave generously to finance this new effort, which was supported by a sister campaign in Quebec promoted by the clergy and francophone elites, raising over $\$ 99,000$ for the cause. ${ }^{258}$

These examples show that conflict between New Brunswick's anglophones and francophones did not disappear as a result of the need to pull together for the war effort,

\footnotetext{
${ }^{256}$ New Brunswick Minister of Education quoted in “À propos de bilinguisme scolaire,” La Voix d'Évangéline, le 16 mars 1944, 3.

257 “Le journal et l'âme nationale," La Voix d'Évangéline, le 27 mai 1943, 3.

258 "Ensemble dans un même effort, Quebec et Acadie," Le Madawaska, le 3 juin 1943, 3; "Un journal acadien," Le Madawaska, le 19 août 1943, 1.
} 
and that francophone self-advocacy was not inspired by the plebiscite vote. Rather, these cases demonstrate Acadian resilience and the continuation of inter-linguistic conflict, which had existed in various forms since the seventeenth century, although the specific subjects of disagreement varied over time and with changing local, national, and world events.

Following the 1942 conscription crisis, a small number of Canadians continued to stir up racial hatred against French Canadians. One of these individuals was Dr. Shields, a Baptist pastor from Toronto and leader of the Canadian Protestant League. Denounced by Le Madawaska as an imperialist extremist, "ce saboteur public de l'édifice de la bonne entente" was accused of travelling throughout English Canada "faisant appel aux préjugés de race et soulevant partout le cri de langue et de religion.” During a Protestant rally in Fredericton, Shields earned the ire of editor Lucien Fortin when he claimed that English Canadians would be the ones dying in Europe while French Canadians remained at home, a statement which, Fortin claimed, was not supported by the official recruitment statistics. ${ }^{259}$ Although quiet for the most part in 1943, conscriptionists and those who believed that the burden of sacrifice was not being shared equally would increase in visibility as the number of recruits began to fall.

By the spring of 1944, the number of army recruits was dwindling. At the same time, a report in L'Évangéline announced that the impending augmentation of Allied operations in Europe would require more men to be pulled from industry and other areas. ${ }^{260}$ According to the National Selective Service, between April 1944 and March

\footnotetext{
259 “Propos d'un fanatique hystérique," Le Madawaska, le 12 août 1943, 3.

260 "Il faut augmenter l'enrôlement au Canada, declare M. Mitchell," L'Évangéline, le 30 mars 1944, 1. La Voix d'Évangéline was renamed L'Évangéline in early March 1944.
} 
1945, 98,000 men were needed for all branches of the service, including home defence conscripts. Measures were in place to secure the required number of men whether through enlistment or call up. ${ }^{261}$ This, according to L'Évangéline, amounted to a system of indirect overseas conscription. If the men targeted by these measures did not enlist voluntarily, they would be conscripted and there remained a distinct possibility of their being sent overseas. Minister of National Defence J.L. Ralston had declared that the conscripts formed a reservoir of reinforcements for overseas if there was ever a need. ${ }^{262}$

In addition to acting as this manpower reservoir, the NRMA served as a powerful motivational force for enlistment. According to Granatstein and Hitsman, approximately 80 percent of volunteers enlisted after being called up under the NRMA. These men avoided the stigma of being conscripted and, more importantly, had more choice over the branch and trade in which they served. Many sought to enter the Air Force or Navy as opposed to the Army, where there was a high chance of being selected for infantry service, which was rightly believed to suffer the most casualties. With this knowledge in mind, the military increased its efforts to call up men in the eligible classes. ${ }^{263}$

While the active service volunteers and conscripted NRMA troops had undergone basic training together since 1941, something that military authorities hoped would encourage the NRMA men to volunteer, pressure on conscripts increased as the manpower shortage grew. The methods used to encourage the NRMA men to convert from reserve to active, or volunteer, status varied in nature and in intensity. Commanding

261 “Les forces armées ont besoin de 98,000 hommes d'ici un an," L'Évangéline, le 12 avril 1944, 1. 262 "Conscription militaire indirecte," L'Évangéline, le 15 juin 1944, 7.

${ }^{263}$ Burns, Manpower, 118-20; Granatstein and Hitsman, Broken Promises, 200. Men eligible to be conscripted were divided into groups, or classes, based on age and marital status. The classes composed of young, unmarried men would be called up first, followed by older and married men as the need arose. 
officers of the training centres often used speeches, personal appeals and public praise of those who volunteered to encourage others to do the same. During one of the largest recruiting parades at No. $71 \mathrm{CA}(\mathrm{B}) \mathrm{TC}$, forty-nine reserve recruits volunteered. Their names and hometowns were subsequently published in the local newspaper. ${ }^{264}$ In some cases, NRMA men were denied leave or transferred to less pleasant duties, in other cases individuals and platoons were promised supplementary leave if the entire platoon went active, a measure which made any man who refused very unpopular amongst his platoon mates. In more extreme but not uncommon instances, conscripted men were subject to harassment by staff and their peers as well as physical intimidation, which was often overlooked by staff. ${ }^{265}$ The pressure lessened somewhat when NRMA men finished their training and were posted to home defence units, as the units were predominantly composed of reserve troops by the later part of the war. ${ }^{266}$ However, in April 1944, a lastditch recruitment campaign was approved to encourage the remaining NRMA men to volunteer. Following the D-Day landings, there was a noticeable surge in recruits going active, although these numbers began to dwindle again in early autumn. Overall, the rates of conversion were lower than what had been expected and needed. By this time, the remaining home defence soldiers had developed a pride in their status and resisted the appeals to volunteer for overseas service. ${ }^{267}$

On 16 June 1944, members of No. 71 CA(B)TC participated in a large recruitment rally held at Edmundston, which was also attended by many local citizens. Speakers, including former members of the training centre staff who had served overseas,

\footnotetext{
264 “Record Number Turn Active," Le Madawaska, le 20 août 1942, 2.

265 Byers, Zombie Army, 158-66.

${ }^{266}$ Granatstein and Hitsman, Broken Promises, 198.

267 Burns, Manpower, 121-4.
} 
stressed the need for reinforcements in the New Brunswick regiments. The war diary indicates that, afterwards, a number of reserve recruits "signified their willingness to join the Canadian active army." 268 Both training centres report recruits going active, often in small groups, although No. $71 \mathrm{CA}(\mathrm{B}) \mathrm{TC}$ sometimes recorded larger groups of fifteen to forty-nine men following the weekly recruiting parade. ${ }^{269}$ The war diaries make no mention of the methods used to encourage men to convert. However, an interview with Burt Harper, an instructor at No. $71 \mathrm{CA}(\mathrm{B}) \mathrm{TC}$, is revealing. Harper reported that active and reserve troops normally mixed amicably, but that during recruiting rallies they would be lined up on opposing sides of the parade square. The band would play, and an officer would make a speech about serving one's country and appeal to the reserve recruits to go active. Those who volunteered would be cheered. This would be repeated a couple of times and then the tone of the speech would change, becoming forceful. Active recruits would be encouraged to hiss and boo the remaining reserve men. At this point no more would volunteer. ${ }^{270}$

Up until September 1944, the army maintained that it had sufficient manpower to meet its needs, even though its overseas headquarters reported in June that heavy casualties would make larger reinforcement drafts necessary in the future. ${ }^{271}$ In late September, stories began to appear of untrained reinforcements and casualties being sent to fight, which, when combined with new information from overseas headquarters on the availability of infantry reinforcements, was cause for alarm. On his annual trip to Europe,

\footnotetext{
${ }^{268}$ LAC, RG 24-C-3, Vol. 17262, File 1252, War Diary Summary of Events, 17 June 1944.

${ }^{269}$ LAC, RG 24-C-3, Vol. 17256, File 1251; RG 24-C-3, Vol. 17260, File 1252. The War Diary Summaries of various months contain records of NRMA troops going active.

${ }^{270}$ Burton Harper, interview by Mike Charrier, Canadian War Museum Oral History Project Interview Transcript, September 26, 2000, 14-16.

${ }^{271}$ Dawson, Conscription Crisis, 13.
} 
Ralston learned the gravity of the situation. Casualties in the infantry had been much higher than predicted, reaching 78 percent in the five weeks following D-Day, as opposed to the 63 percent revised rate estimated by the British War Office. Pools of infantry reserves in Italy and northwest Europe were nearly exhausted and efforts to convert other surplus troops to infantry were insufficient to meet the immediate need. Upon his return, Ralston presented his findings to Cabinet. Fifteen thousand infantry were needed immediately and, as the NRMA formed the largest reserve of trained infantry, Ralston was convinced that sending them overseas was necessary to provide adequate reinforcements for the units at the front. King, who had built his political career on maintaining unity between French and English Canada, saw in this recommendation the seeds of disunity. With the war drawing to a close, he found it difficult to believe that the required number of troops could not be obtained voluntarily. ${ }^{272}$

Even with the Cabinet divided over the decision whether or not to send the NRMA overseas, King was not ready to concede defeat of the voluntary system. He made the difficult decision to fire Ralston by accepting the resignation which Ralston had submitted during the first conscription crisis but had neglected to withdraw. King replaced Ralston as Minister of National Defence with General Andrew McNaughton, the former Commander of First Canadian Army and promoter of the voluntary system. Believing that sufficient volunteers could be obtained from the NRMA if only they were appealed to in the right way, McNaughton asked the government to give the voluntary system one last chance. ${ }^{273}$ This time, platoon and unit commanders would attempt to appeal personally to NRMA members, stressing the great need for volunteers. Yet

272 Burns, Manpower, 90-92, 96-98; Dawson, Conscription Crisis, 14-19.

${ }^{273}$ Dawson, Conscription Crisis, 35-47, 56-8; Granatstein and Hitsman, Broken Promises, 218-21. 
appeals for the conscripts to volunteer were largely unsuccessful. McNaughton had greatly underestimated the resistance of NRMA men to going active. ${ }^{274}$ After taking into account the opinions of his District Officers Commanding, and receiving a memo from the Military Members of the Army Council in which the signatories advised that the voluntary system could no longer meet the needs of the army, McNaughton recommended to King that some of the NRMA men be sent overseas. ${ }^{275}$ McNaughton's advice was a blow to King, but it also provided him with a timely reason to change his strategy, allowing him to bring in conscription and quiet the growing dissent within his own party, which threatened to bring down the government, while demonstrating to French Canada that he had done everything possible to avoid conscription. ${ }^{276}$ On 23 November, an order-in-council authorized the sending of up to 16,000 conscripts overseas. Although French Canadian MPs were shocked by the sudden reversal of policy, only Air Minister Power resigned from Cabinet. The government survived a vote of confidence put forward by Mackenzie King on 27 November. ${ }^{277}$

The New Brunswick newspapers closely followed the second conscription crisis as it unfolded in Ottawa. In New Brunswick, as elsewhere in Canada, the reinforcement situation overseas led to increased calls for conscription from anglophones and animosity towards French Canadians. The Fredericton branches of the Legion and the Imperial Order Daughters of the Empire, as well as the St. Stephen Legion and the women's

\footnotetext{
${ }^{274}$ Granatstein and Hitsman, Broken Promises, 224-6. McNaughton did not make any attempt to personally appeal to the NRMA either by visiting camps or via radio which further hurt his chances of raising the required reinforcements, Dawson, Conscription Crisis, 65-67.

${ }^{275}$ Dawson, Conscription Crisis, 67-73, 83-85; Granatstein and Hitsman, Broken Promises, 225-9. Chief of the General Staff General Murchie's letter on behalf of the Military Members of the Army Council appears in Stacey, Arms, Men and Governments, 471.

${ }^{276}$ Granatstein and Hitsman, Broken Promises, 228-9.

${ }^{277}$ Dawson, Conscription Crisis, 115-23.
} 
Legion Auxiliary, passed resolutions calling on the government to "act on the mandate of the plebiscite" and immediately send overseas all fully trained personnel called up under the NRMA. ${ }^{278}$ Le Madawaska published extracts from a speech by anglophone newspaper editor and former army officer David MacLellan, who called on anglophone Canadians to stop "la campagne stupide et avilissante menée contre le Québec," reminding them that two-thirds of the conscripts were from other provinces. ${ }^{279}$ During a radio broadcast on 8 November, King also attempted to correct the false assumption that most conscripts were French Canadian, stating that, of the 60,000 NRMA men, 23,000 were from Quebec and only 25,000 in all of Canada were French speaking. ${ }^{280}$ While many anglophones at the time attempted to explain the NRMA men's reluctance to go overseas by writing them off as foreign or francophone and thus removed from AngloCanadian society and ideals, Byers' research supports the statements of MacLellan and King. He concludes that the number of francophones in the NRMA was not as high as had previously been believed; at most, no more than 40 percent of the NRMA were French Canadian and the number was likely lower. ${ }^{281}$

The francophone papers remained opposed to the idea of conscription for overseas service. On 2 November, Le Madawaska reported that, despite the pressure imposed on him by proponents of overseas conscription including Ralston, "M. King, de son côté, fidèle à l'engagement qu'il a pris devant l'électorat, refuse de se rendre à cette demande." ${ }^{282}$ L'Évangeline editor Leandre LeGresley made no attempt to hide his disdain

278 "Canadian Legion I.O.D.E. Demand Immediate Action," Daily Gleaner, 20 November 1944, 7, 10; “St. Stephen Legion for Reinforcement," Daily Gleaner, 21 November 1944, 7.

279 "Une campagne stupide et avilissante menée contre Québec," Le Madawaska, le 30 novembre 1944, 14.

280 "King Radio Broadcast," Daily Gleaner, 9 November 1944, 7.

${ }^{281}$ Byers, Zombie Army, 125, 132-3.

282 “M. King refuse d'imposer la conscription pour outremer," Le Madawaska, le 2 novembre 1944, 1. 
for those whom he viewed as imperialist-minded conscriptionists. An editorial from 16 November shows that LeGresley was not convinced of the necessity of conscription, at least while King and McNaughton still held out hope that the reinforcements could be found through the voluntary system. Much of his discontent was directed at the Angloconscriptionist imperialists, whom he believed were seeking to put the interests of the Empire before those of Canada. He pointed out that most of the conscripts were anglophones. Instead of leading a slander campaign against francophones who were doing their part, conscriptionist papers would be better served by attempting to convince their own to volunteer. ${ }^{283}$ Even after the government passed its order-in-council to send 16,000 conscripts overseas, LeGresley remained unconvinced that the measures were necessary. His reaction also betrayed his fears for the future of French Canadians. How absurd it was that they were being forced to fight overseas for democracy and Christianity when their own language and religious rights were not respected at home by the very majority who claimed to be protecting these principles overseas. However, LeGresley concluded, "il faut se soumettre à la loi du pays.",284

Despite the opposition of the Acadian press to conscription, the Acadian MPs remained supportive of King throughout this second conscription crisis. After Power's resignation, Michaud, now Transport Minister, continued to support King along with the remaining Quebec cabinet members. ${ }^{285}$ Michaud and Veniot voted with the Prime Minister on all motions throughout the 1944 crisis. Aurel Léger, who had been torn between supporting King and upholding the views of his constituents during the debate

\footnotetext{
283 “Bravo, M. King," L'Évangéline, le 16 novembere 1944, 3.

284 "Nous avons maintenant la conscription pour outre-mer," L'Évangéline, le 30 novembre 1944, 3.

285 “Coup d'oeil à Ottawa,” L'Évangéline, le 30 novembre 1944, 7.
} 
over Bill 80, was the only Acadian to vote against the government's position during the 1944 conscription debates in the House, although he voted alongside King in the confidence motion. ${ }^{286}$

The French-Canadian population reluctantly accepted conscription. King's decision to accept Ralston's resignation and his willingness to give the voluntary system one last chance, coupled with his decision to send only the number of conscripts required to resolve the reinforcement crisis, demonstrated that the Prime Minister did everything possible to avoid conscription. Except for the exaggerated reports of mutiny by some of the NRMA in British Columbia and sporadic demonstrations in Quebec, conscription was adopted with less hostility than in 1917 . Ultimately, only 2,463 of the NRMA recruits would fight in operational units. Unit commanders believed the NRMA men fought as well as the volunteers and were often indistinguishable from them. ${ }^{287}$ In Canada, the animosity between conscriptionists and anti-conscriptionists declined rapidly. ${ }^{288}$ By the end of the war, the Acadians had more pressing matters to attend to, most notably the poor state of Acadian schools. While they hoped that it would not be necessary to "faire une guerre contre notre gouvernement pour nos propres droits," they were prepared to do so. ${ }^{289}$ Looking to the future with their attention focused on achieving equal rights and representation, in the years leading up to the adoption of the Official Languages Act, conscription gradually faded from the memories of New Brunswick Acadians. ${ }^{290}$

\footnotetext{
${ }^{286}$ Nugent, "The Acadian Response," 65-67.

287 Byers, Zombie Army, 237.

${ }^{288}$ Dawson, Conscription Crisis, 123-5; Granatstein and Hitsman, Broken Promises, 232-5; "Terrace, B.C., Centre of Disturbances," Daily Gleaner, 28 November 1944, 1, 7; "Demonstrations at Loretteville, Que," Daily Gleaner, 30 November 1944, 5.

289 "Un Acadien écrit ce qu'il pense de notre mauvais système d'éducation," L'Évangéline, le 24 mai 1944, 2.

290 “Official Languages in New Brunswick: Historical Benchmarks," Office of the Commissioner of Official Languages for New Brunswick, accessed 2 August 2019, http://officiallanguages.nb.ca/
} 


\section{Chapter Four}

\section{Acadian Participation}

The desire of many anglophone Canadians to send the conscripts overseas as reinforcements was motivated by a belief in the necessity of conscription to provide reinforcements, and by concerns over unequal sacrifice. Their concerns were heightened by segments of the anglophone press, which accused Quebec of being anti-British, isolationist, fascist, and of not providing as many volunteers as other provinces. ${ }^{291}$ As the military did not record the first languages of volunteers, it was impossible to compare the war efforts of French and English Canada, which made anglophones suspect that French Canadian participation was worse than it was, while French Canada was led by its politicians to believe their participation was more than adequate. Both groups judged the war effort differently. In addition to military service, francophones considered civilian voluntary service as part of their overall war effort, while anglophones tended to think of participation in terms of enlistment. While much of this concern over French Canadian participation was aimed at Quebec, Acadians were also affected and were anxious to demonstrate their commitment to the war effort. This chapter will explore the various ways, both military and non-military, in which New Brunswick Acadians supported the war effort as well as some of the challenges or barriers to their participation. ${ }^{292}$

\footnotetext{
publications-links-other/history-official-languages. Enacted 18 April 1969, the Official Languages Act specified English and French as the two official languages of New Brunswick. It also recognized the right of individuals to receive government services in the official language of their choice. More language reforms would follow in subsequent years. Nugent's research seems to support this. In interviews conducted for her thesis in 1982, Nugent found that Maritimers remembered Acadian participation in the war effort but could not recall any opposition to conscription. See Nugent, "The Acadian Response," 92-94. 291 “Les attaques contre Québec," L'Évangéline, le 7 septembre 1944, 3.

292 Jean Pariseau and Serge Bernier, French Canadians and Bilingualism in the Canadian Armed Forces Volume I 1763-1969: The Fear of a Parallel Army (Ottawa: Department of National Defence, 1988), 1202; Mason Wade, The French Canadians 1760-1967, vol. 2: 1911-1967 (Toronto: Macmillan, 1968), 954, 960-1.
} 
As previously mentioned, part of the concern surrounding French Canada's participation stemmed from the inability to determine how many francophones, Acadian or otherwise, had enlisted for active service, since recruits were not asked about their linguistic background upon enlistment. There was no official tally of the number of Acadians who served, a factor that resulted in various estimates with varying degrees of accuracy, which often seem to be linked to the argument made by the estimate's creator. Throughout the war, both federal and provincial Acadian politicians praised what they saw as the remarkable participation rate of young Acadian men. New Brunswick Minister of Health and Labour and Gloucester MLA J. André Doucet remarked that young francophones from the province were responding generously to the calls to enlist. He estimated that nearly half of the recruits undergoing training at the Fredericton training centre were francophones. ${ }^{293}$ In a speech in the House on 13 February 1942, Kent MP Aurel Léger claimed that conscription was not necessary because the country already had all the volunteers it was capable of training, and volunteers were still enlisting in large numbers, even in the French Canadian population. Acadians, he claimed, were doing more than their share, comprising 40-45 percent of New Brunswick enrollments, even though they only formed one third of the population. ${ }^{294}$

In his assessment of Acadian military participation, Ronald Cormier used enrollment figures from the Department of National Defence, casualty figures, and population statistics to estimate the number of New Brunswick Acadians who served. He

\footnotetext{
${ }^{293}$ Legislative Assembly of New Brunswick, Synoptic Report, 11 March 1942, 103. It is not possible to assess the accuracy of Doucet's claim; however, it is likely that a number of these men were not volunteers, by 1942 the basic training centres were training both those who had enlisted for active service and those conscripted under the NRMA.

${ }^{294}$ Aurel Léger in House of Commons, Debates, 13 February 1942, 590. When asked by Hanson, Léger stated that the numbers were provided by an army officer. Although Hanson claimed he was not disputing Léger's statement, the numbers, when compared to estimates from other sources appear quite inflated.
} 
concludes that Acadians represented just over 30 percent of New Brunswick enrollments, roughly equivalent to their share of the population. ${ }^{295}$ Mélanie Morin-Pelletier examined recruitment figures in Madawaska in her article on Réné Morin, a conscript from Edmundston who served overseas. She notes that the enrollment rate for young men of military age in the county was just over 20 percent, significantly lower than the national average of 40 percent and the provincial average of 48 percent. She suggests there are multiple explanations for these low recruitment numbers, ranging from not being convinced that the war was a threat to Canada, to the need to remain at home to work on the family farm or in the woods, or to fears that they would be discriminated against in a largely anglophone military. Her analysis of Le Madawaska's coverage of the local civilian war effort suggests that, like other francophones, Madawaska Acadians believed non-military participation to be an equivalent form of support for the war effort. ${ }^{296}$

Morin-Pelletier's analysis does not take into account that hundreds of men from northern New Brunswick chose to enlist in Quebec units. Prior to mid-1940, there was no recruiting centre along the North Shore outside of recruiting for the Carleton and York Regiment at Edmundston, and it was much easier for these men to enlist in the Gaspé rather than travel to Fredericton or Moncton at their own expense to enlist. ${ }^{297}$ Joining a Quebec unit was also the only option for Acadians who wished to serve in their own language, since there were no francophone units in the Maritimes. An article appearing in Le Madawaska in October 1941 outlined the various options available at the francophone units in Quebec, which, in addition to infantry, included engineers, artillery, and a field

\footnotetext{
${ }^{295}$ Cormier, Acadiens et la Seconde Guerre, 98-100.

${ }^{296}$ Morin-Pelletier, "Récit de Guerre d'un Conscrit," 48-49.

${ }^{297}$ House of Commons, Debates, 12 November 1941, 4327-8.
} 
ambulance. $^{298}$ The MP for Royal, Alfred Brooks, reported in 1941 that between two and three thousand New Brunswickers enlisted in Quebec, where, according to J.E. Michaud, they were added to the Quebec recruiting totals instead of those of their home province. ${ }^{299}$ According to Air Minister Power, three Quebec units, $57^{\text {th }}$ Battery, Régiment de la Chaudière, and the Royal Rifles of Canada, recruited along the Quebec-New Brunswick Border. ${ }^{300}$ Hong Kong prisoner lists published in the Daily Gleaner confirm that a number of New Brunswickers joined the Royal Rifles. Photos from the francophone papers also demonstrate that a number of Acadians joined the Royal $22^{\mathrm{e}}$ Régiment. ${ }^{301}$ Smaller numbers of New Brunswick Acadians joined units in Nova Scotia and in the United States.

While some Acadians chose to enlist in other provinces, most joined the units near their hometowns in New Brunswick, even though that meant serving in English. The largest number of Acadians could be found in the ranks of the North Shore Regiment, which recruited in northern and eastern New Brunswick. According to Lieutenant Placide Labelle, one fifth of the regiment was made up of Acadians, many of whom had worked in fishing and forestry before the war. While Labelle reported that the majority spoke English, this unit had sufficient Acadian officers and NCOs to be able to provide

\footnotetext{
298 "Positions avantegeuses offertes dans les unites essentiellement canadiennes-français," Le Madawaska, le 9 octobre 1941, 5.

${ }^{299}$ House of Commons, Debates, 12 November 1941, 4328-9. Brooks personally believed that fewer than two to three thousand Acadians had enlisted in Quebec by 1941. In his estimation of Acadian military participation, Cormier estimates that two thousand Acadians enlisted in Quebec during the entire war. See Cormier, Acadiens et la Seconde Guerre, 100.

${ }^{300}$ House of Commons, Debates, 12 November 1941, 4329. These were not the only Quebec units in which Acadians could be found.

301 "More N.B. Soldiers Hong Kong Prisoners," Daily Gleaner, 3 November 1942, 2; Photo "Douze Acadiens de Nouveau-Brunswick avec le Royal 22e," L'Évangéline, le 11 janvier 1945, 1. While 12 were pictured, the caption stated that there were numerous other New Brunswickers serving with the regiment.
} 
instruction in French for those who were not sufficiently bilingual. ${ }^{302}$ According to its regimental historian, Robert Tooley, D Company of the Carleton and York Regiment was made up of men from the Edmundston area, many of whom were francophones. ${ }^{303}$

Acadians could be found in virtually all army units recruited in the Maritimes, although, as previously indicated, most served in the infantry. Low levels of educational attainment barred Acadians from serving in many technical trades, as did the language barrier for those who were not sufficiently bilingual since, with the exception of a few courses offered in Quebec, most training was conducted in English. ${ }^{304}$ English was also the language of operation for all units except for a few designated francophone army units in Quebec. According to C.P. Stacey, it was in the army that the language "problem presented itself in the most acute form. ${ }^{305}$ However, as Pariseau and Bernier point out, this was only because the air force and navy operated almost exclusively in English. ${ }^{306}$

The Royal Canadian Navy ( $\mathrm{RCN}$ ) appears to have been the most difficult branch of the military for francophones to enter because the navy made no attempt to operate as a bilingual institution. ${ }^{307}$ Even if they met the bilingualism requirement, entry was still just out of reach for many Acadians as most did not meet the educational requirements. The navy preferred to recruit men with a high school education or technical skills over those who possessed seagoing experience. This concerned members of the Ordre de

\footnotetext{
302 “Les Acadiens en Angleterre," La Voix d'Évangéline, le 3 septembre 1942, 1, 7.

${ }^{303}$ Robert Tooley, Invicta: The Carleton and York Regiment in the Second World War (Fredericton, NB: New Ireland Press, 1989), 11; Cormier, Acadiens et la Seconde Guerre, 90.

${ }^{304}$ Pariseau and Bernier, Bilingualism in the CAF, 122-7. Only 4 percent of those who took trades courses received their training in French.

${ }^{305}$ Stacey, Arms, Men and Governments, 420.

${ }^{306}$ Pariseau and Bernier, Bilingualism in the CAF, 127.

307 The idea of creating a francophone ship was dismissed early in the war as being too difficult to achieve interoperability and because sufficient trained officers and NCOs would not have been available. A short language course was put in place for francophone recruits prior to the commencement of their training; however, it was insufficient as recruits were required to be functionally bilingual.
} 
Jacques-Cartier because many young Acadian fishermen had expressed interest in joining the navy, believing they could be of better use there. ${ }^{308}$ The 10 July 1942 meeting minutes of the OJC Edmundston branch indicate that the Order wanted the local city and county councils and the directors of La Cooperative du Madawaska to act as petitioners to the Minister of National Defence and the Minister of Fisheries, asking for "l'acceptation de fils de pêcheurs français dans la marine canadienne."309

Even though it also had high educational standards and knowledge of English was required, the Royal Canadian Air Force (RCAF) was more welcoming to Acadians than the navy, although here too their level of representation was much less than in the army. In his MA thesis on the Acadians in Nova Scotia during the Second World War, Ryan d'Eon mentions that the RCAF actively tried to recruit Acadians. ${ }^{310}$ The same was true in New Brunswick. Recruiting advertisements in French and English for the RCAF appeared in the French-language press, while the RCAF Mobile Recruiting Unit made stops in towns along the North Shore. The Daily Gleaner reported that a number of New Brunswick Acadians could be found among the ground crew of No. 425 'Alouette' Squadron. ${ }^{311}$ Acadians also served as aircrew, both with No. 425 Sqn and others, including in the Royal Air Force. ${ }^{312}$

While Acadians served in all branches of the armed forces, they did not have a unit that they could call their own. Unlike in the previous war, the army made no attempt at forming an Acadian unit. This was a major disappointment for La Voix d'Évangéline

\footnotetext{
${ }^{308}$ House of Commons, Debates, 11 November 1941, 4264-5.

${ }^{309}$ Centre d'études acadiennes Anselme-Chiasson, Fonds 1165 Ordre de Jacques-Cartier - cellule FrançoisCiquart Edmundston, Procès-verbal, le 10 juillet 1940.

310 d'Eon, "Away but Still at Home," 101-2.

311 "New Brunswick Men in New Squadron," Daily Gleaner, 12 August 1942, 4.

312 “Campbellton Flier Dropped Hun Plane," Daily Gleaner, 22 August 1942, 2.
} 
which, since 1940, had been publicly calling for the creation of an Acadian unit commanded by Acadian officers, with which the soldiers themselves and the population at large could identify. ${ }^{313}$ The proposed unit never garnered much political or military support because it was believed there would be insufficient men available to fill and reinforce the unit, and because the politicians promoting it did not carry enough weight in military and political circles. ${ }^{314}$ In 1942 , the army attempted to improve French-Canadian representation in the officer corps by training more French-speaking officers, including a number of Acadians, in special programs. This led to renewed, albeit unsuccessful, calls by La Voix d'Évangéline for an Acadian unit in 1942 and 1943. The paper claimed that the Acadians had provided more than enough volunteers to fill a unit of their own and that such a unit would be a rallying point for the population, allowing it to participate in the war effort on a more equal footing. ${ }^{315}$

Despite not having a unit of their own, and despite being largely ignored by military recruiters until the start of the first official recruitment campaign in May 1941, many Acadians were still eager to enlist. Some ads targeted francophones and Acadians directly, but most were mere translations of the ads featured in anglophone papers. Many recruiting ads appealed to potential recruits' masculinity, patriotism, and sense of duty towards the nation.

Individual Acadians' reasons for enlistment were varied and often mixed. In a letter published in La Voix d'Évangéline, Lionel Cormier wrote that he enlisted to follow

313 "Un camp bilingue, mais pour qui?" La Voix d'Évangéline, le 10 octobre 1940, 3.

${ }^{314}$ Cormier, Acadiens et la Seconde Guerre, 72-74; "Une réorganisation radicale," La Voix d'Évangéline, le 9 octobre 1941, 3 .

315 "À propos de nominations récentes - À quand un brigadier acadien et une unite acadienne?" La Voix d'Évangéline, le 28 mai 1942, 3; “Quant à nous, rien...” La Voix d'Évangéline, le 11 février 1943, 3. 
his brother and friends, to see the world, and learn practical skills. ${ }^{316}$ Lack of employment played a large role, especially among those who enlisted earlier in the war since the Acadians, who were often dependent on anglophones' companies for jobs, were particularly hard hit by the Depression. ${ }^{317}$ Regarding his decision to join the army, Joseph LeBouthillier remarked, “j”'étais un jeune homme de 19 ans ... qui devait gagner sa vie. Le seul choix, c'était l'armée. Il n'y avait absolument pas de sentiment patriotique attaché à ma decision. ${ }^{318}$ In the army, LeBouthillier was fed, clothed, and earned $\$ 25$ per month. He earned only 25 cents per day prior to enlisting. While Acadians' reasons for enlisting varied, they were clearly different from those of many English Canadians, whose motivations were much more likely to be British-Empire minded and who joined up to aid Britain in its time of need.

For the Acadian servicemen, whether conscripted or volunteer, the experience of military life varied depending on the camp or unit where they were posted and the attitudes of peers and superiors towards francophones. After October 1940, some Acadians were able to complete part of their basic training in French in Edmundston. ${ }^{319}$ La Voix d'Évangéline applauded this decision, stating that "la presence ... d'instructeurs bilingues, est chose absolument indispensable" ${ }^{\text {220 }}$ to the training of Acadian soldiers;

\footnotetext{
316 “Lettre de Lionel Cormier," La Voix d'Évangéline, le 9 septembre 1943.

${ }^{317}$ Cormier, Acadiens et la Seconde Guerre, 12-13.

${ }^{318}$ Cormier, J'ai vécu la guerre, 127.

${ }^{319}$ No. 70 CA(B)TC in Fredericton and No. 71 CA(B)TC in Edmundston were initially NPAM training centres from 9 October 1940 to 14 February 1941. They were redesignated Army Basic Training Centres on 15 February 1941 with the decision to extend the length of training under the NRMA to four months. This decision also saw active and conscripted troops begin to train together. They were redesignated Canadian Infantry (Basic) Training Centres on 15 November 1943 when the army switched from using a common basic training system with branch specific advanced centres to streamlining troops into branch specific schools from the start. For a list of army training centres, see C.P. Stacey, Official History of the Canadian Army in the Second World War, Volume 1: Six Years of War the Army in Canada, Britain and the Pacific (Ottawa: Queen's Printer, 1955), 528-35.

320 "Camps d'entraînement bilingues en Ontario, au Québec, au N.-Brunswick," La Voix d'Évangéline, le 19 septembre 1940, 3.
} 
however, it lamented that this training centre was only for men from Madawaska,

Restigouche, Gloucester, and Northumberland counties. Acadians from other counties were sent to the anglophone training centre in Fredericton and there were no bilingual centres at all in Nova Scotia and Prince Edward Island. ${ }^{321}$ To help some of its francophone trainees, who arrived with little to no prior knowledge of English, No. 70 CA(B)TC in Fredericton began offering evening courses in conversational English. ${ }^{322}$ Pariseau and Bernier also indicate that there was some attempt by the training centre's Commanding Officer, Lieutenant Colonel A.J. Brooks, and Major G.F.G. Stanley to have francophones train in French. ${ }^{323}$ While many unilingual francophones initially had difficulty because of their unfamiliarity with English, some, such as Fidèle Landry, saw this as their opportunity to learn the language and asked to be sent to an anglophone regiment. $^{324}$

The decision to locate a bilingual training centre in Edmundston was made for linguistic, geographic, political and economic reasons. Located at a railway hub, the city was easily accessible by train from other parts of the province. Despite requests by Edmundston mayor J. Hervé Proulx to have his city chosen as the site for a bilingual training centre, it was largely due to the lobbying efforts of local MP and sole Acadian federal Cabinet Minister J.E. Michaud that the mayor's request was eventually accepted.

321 "Un camp bilingue, mais pour qui?" La Voix d'Évangéline, le 10 octobre 1940, 3; "Encore à propos du seul camp bilingue au N.-B." La Voix d'Évangéline, le 17 octobre 1940, 3. The paper acknowledges in its 17 October article that New Brunswick francophones from other counties could train in Edmundston if they were able to get permission from the correct authority in time. However, it appears as if most recruits were unaware of this option, nor was it indicated who this authority might be.

${ }^{322}$ LAC, RG 24-C-3, Vol. 17255, File 1251, Folder 4. Courses Offered, 29 January 1942.

${ }^{323}$ Pariseau and Bernier, Bilingualism in the $C A F, 125$. This basic training centre was not officially bilingual, it is unclear how much French was actually used there for instruction purposes.

${ }^{324}$ Cormier, J'ai vécu la guerre, 88. 
Construction of the camp provided work to approximately 225 local men in an area that was still struggling to recover from the Depression. ${ }^{325}$

Training consisted of classroom and practical instruction on various subjects such as weapons handling, first aid and map reading, among many others. A significant amount of time was devoted to physical training, including marching, drill, and sports. ${ }^{326}$ Illiterate troops presented a problem at basic training centres, where they were unable to pass map reading or written tests. ${ }^{327}$ This was a problem in New Brunswick, which had the highest illiteracy rates in Canada, especially among francophones. Special courses were offered at No. $70 \mathrm{CA}(\mathrm{B}) \mathrm{TC}$ in Fredericton to teach these men to read and write. No. $71 \mathrm{CA}(\mathrm{B}) \mathrm{TC}$ in Edmundston offered a special four-month educational basic program, which taught basic literacy and numeracy in addition to the standard basic training curriculum. $^{328}$

After supper and following mandatory Sunday religious services, recruits had free time. Activities were organized by the camp staff and local community to help recruits occupy their leisure. Organized sports such as boxing, hockey, and baseball were popular and camp teams competed in their local sports leagues. Community volunteer organizations put on plays, talent shows, musical soirées and other forms of entertainment. The Knights of Columbus hut provided a space for recreation organized by the recruits themselves; it housed a canteen, piano, and a small library. The importance of

\footnotetext{
${ }^{325}$ Georges Sirois, "Centre d'instruction (élémentaire) No. 71 d'Edmundston, 1940-1945," Revue de la Société historique du Madawaska, juillet 1993, 4-5.

${ }^{326}$ LAC, RG 24-C-3, Vol. 17258-17263. File 1252. Training syllabi can be found in the No. 71 CA(B)TC war diaries for most months of the war.

327 “Joliette Has School for French Soldiers," Daily Gleaner, 27 November 1942, 3.

${ }^{328}$ LAC, RG 24-C-3, Vol. 17255, File 1251, Folder 4. Courses Offered, 29 January 1942; LAC, RG 24-C3, Vol. 17261, File 1252, Folder 8. War Diary Summary of Events, 1 July 1943. The No. 71 CA(B)TC War Diary reports that a new Educational Basic system was set up with the help of former teacher Captain Theriault of 7 District Depot.
} 
these huts at home and overseas was underscored by Le Madawaska as both places of leisure and of the Catholic faith, where soldiers could easily visit with priests. ${ }^{329}$ Despite the local francophone population's generous support for the Knights of Columbus huts and organizations that provided books for troops, Le Madawaska noted that francophones had once again been shortchanged. In 1943, Lucien Fortin noted that, while the library at No. $71 \mathrm{CA}(\mathrm{B}) \mathrm{TC}$ contained numerous English books, there were almost none available in French. The situation changed little until the summer of 1944 when Sergeant T.-E. Normandeau arrived at the centre after serving four years overseas. After lobbying army educational services in Ottawa and the Canadian Legion, Normandeau succeeded in obtaining four hundred French-language volumes for the camp library. While satisfied with the outcome, Fortin lamented that it had taken nearly until the end of the war for the problem to be resolved, seeing in this small matter another sign of Acadians' inferior position within the province, especially since there had never been any question of access to English-language reading materials. ${ }^{330}$

Over the course of the war, the centre provided basic training to 7250 recruits, the majority of whom were francophones from northern New Brunswick. ${ }^{331}$ Sirois writes that no references to inter-linguistic conflicts could be found in the documents about No. 71 CA(B)TC. Francophones and anglophones seemed to cooperate harmoniously during the five years that the camp was in operation. The majority of camp staff was bilingual and,

\footnotetext{
329 "Une hutte des Chev. De Colomb au camp local," Le Madawaska, le 3 octobre 1940, 1, 6. French Canadians were encouraged to donate generously to supporting these huts which provided for the spiritual well-being of Catholic troops and served a counter to the other huts operated by the YMCA or Salvation Army which were religiously neutral (nominally Protestant).

330 "Donnons des livres français à nos recrues," Le Madawaska, le 23 septembre 1943, 3; "Le livre français au camp 71," Le Madawaska, le 1 mars 1945, 3.

331 "Livres pour nos recrues," Le Madawaska, le 11 octobre 1945, 1.
} 
although English was the language of administration, this did not appear to cause any concern within the camp or with the local francophone elites. ${ }^{332}$

Not everyone was happy with the idea of francophones and anglophones being separated in the basic training centres. Lieutenant Colonel Brooks stated that there should only have been one training centre established for all of New Brunswick and that "at a time when we are talking of unity in this country and trying to bring our people together, a splendid opportunity was lost...in not establishing only one training centre for the province where French and English-speaking boys could have come together...."333 Le Madawaska countered that it was only right that New Brunswick should have at least one bilingual training centre, and that Brooks might be less opposed to the idea of separate centres if the Quebec anglophones were forced to undergo their training at francophone training centres. According to Lucien Fortin, in a country with citizens of diverse backgrounds, goodwill is signified by "la reconnaissance en toutes occasions des droits de l'une et de l'autre race, un traitement equitable de la majorité envers la minorité." ${ }^{334}$ A number of Acadians stated that they did not experience discrimination during their time in the military. Others reported varying amounts of negative assumptions about and behaviours toward French Canadians. A letter written by a Lieutenant Essa (a pseudonym for Alexandre J. Savoie), published in L'Évangéline, highlights one of these negative assumptions. During an interview, the Director of Education for the Canadian Army innocently asked Savoie, "Can you explain to me why the Acadians are mostly all

\footnotetext{
${ }^{332}$ Sirois, "Centre d'instruction No. 71," 14.

${ }^{333}$ House of Commons, Debates, 15 November 1940, 155. Brooks is commanding officer of the training centre in Fredericton at this time.

334 "Quand nos droits sont reconnus..." Le Madawaska, le 28 novembre 1940, 3, 11. It is unclear from Brooks' statement whether, if only one training centre had been established, the francophone recruits would have been instructed in French or forced to learn in English. Fortin probably assumed the latter.
} 
illeterate [sic]?"335 Several Acadians interviewed by Ronald Cormier reported that anglophones and francophones were not always treated equally. Laurie Cormier, a member of a bomber crew, reported that occurrences such as being passed over for promotion while less experienced anglophones were promoted, demonstrated to francophones that they were not seen as equals. ${ }^{336}$ Joseph LeBouthillier noted that, when he was admitted to the Veterans' Hospital in St. John, francophone patients were told that they were not permitted to speak French, even among themselves. ${ }^{337}$

The limited opportunities for francophones in all branches of the military made it difficult for them to participate on an equal footing with their anglophone counterparts. The lack of options for soldiers who primarily spoke French and wished to train and serve in their own language meant that the infantry was frequently the only choice available to them, a factor which likely discouraged some from enlisting. It was widely known that the infantry had suffered a disproportionate number of casualties in the First World War. It can be noted, ironically, that New Brunswick Acadians were also less likely to be found fit for front line service. ${ }^{338}$ This put them in a difficult position since the infantry, along with the other combat arms, had the highest medical requirements. More of these men might have been willing and able to enlist in some other role had more options been available to them.

Despite the discrimination faced by some Acadians and the lack of a distinctive unit of their own, Acadians served willingly as volunteers and in the NRMA. They

335 "Un Acadien écrit ce qu'il pense de notre mauvais système d'éducation," L'Évangéline, le 24 mai 1945, 2.

${ }^{336}$ Ronald Cormier, Entre bombes et barbelés: Témoignages d'aviateurs et de prisonniers de guerre acadiens 1939-1945 (Moncton, NB: Éditions d'Acadie, 1990), 95-96.

${ }^{337}$ Cormier, J'ai vécu la guerre, 138.

${ }^{338}$ House of Commons, Debates, 12 November 1941, 4328. 
proved themselves to be good soldiers, sailors, and airmen; a number were decorated for their service and their actions were praised by their communities and in their local newspapers. Lieutenant Fernand Normandeau of Edmundston was promoted to Captain and awarded the Military Cross for his actions during the battle for Ortona on 31 December 1943. After his company commander was injured in an attack on an entrenched enemy position, Normandeau took command of the company and led it in a successful attack on a machine gun nest with nothing but a shovel in his hands after having lost his weapon. ${ }^{339}$ Pilot Officer Ronald Dubé was awarded the Distinguished Flying Cross for skill, courage, and dedication to duty after completing forty-six missions as a rear gunner in a bomber squadron where he was the only French Canadian. ${ }^{340}$ Private Fabien-Georges LeBlanc of Campbellton was awarded the Military Medal for determination and bravery in the face of danger for preventing the enemy from flanking a friendly platoon, which allowed his company to repel the attack by two enemy companies west of San Leonardo. ${ }^{341}$

While a number of New Brunswick Acadians served in a military role, either as volunteers or in the NRMA, most Acadians remained at home and supported the war effort in non-military ways. It was possible for many Acadians to contribute to the war effort through their civilian jobs. Farmers were encouraged to increase production over pre-war levels and the surplus was sent overseas to feed Britain's starving population. Most Acadian farms were small and unable to produce large surpluses; however, by feeding the farmers' families and local communities, they allowed larger producers to

\footnotetext{
339 "La Croix Militaire au Capitaine Fernand Normandeau d'Edmundston," L'Évangéline, le 4 mai $1944,4$. 340 “Retour au pays du sous-lt d'Av. R. Dubé, D.F.C.” Le Madawaska, le 13 avril 1944, 1.

341 “La Medaille Militaire à F.-G. Leblanc,” Le Madawaska, le 25 mai 1944, 9.
} 
send a greater portion of their harvest overseas. ${ }^{342}$ The pressure on farmers to increase production was at odds with attempts at military recruitment. Most Acadian farms were small, family operations without outside help; consequently, a number of young men chose not to enlist because they believed they could be of more use on the farm. Some were thus able to obtain postponements of service under the NRMA, while others who were conscripted but able to remain in New Brunswick were sometimes able to obtain agricultural leave to help with the harvest. ${ }^{343}$ Fish became a more important source of protein in Canada as pork and beef were increasingly sent overseas. Fishers, however, were not awarded the same postponements of military training as farmers were. ${ }^{344}$

During the war years, Acadians supported the war effort through numerous volunteer organizations in their communities. Some of these organizations, such as the Red Cross and the Filles d'Isabelle, offered opportunities for women to participate in the war effort. A number of these organizations had branches in Acadian communities prior to the war and changed the focus of their efforts to support the war effort. In September 1941, the Edmundston branch of the Red Cross reorganized its executive as "in view of the great increase in work due to the war ... it was deemed advisable to have all members of the executive able to converse fluently in both English and French."345 The list of executive officers and subsequent articles pertaining to activities of the local branch demonstrated that anglophone and francophone women worked together to raise funds for injured soldiers, prisoners of war, and displaced civilians in occupied countries. Knitting

\footnotetext{
${ }^{342}$ Ian Mosby, Food Will Win the War: The Politics, Culture, and Science of Food on Canada's Home Front (Vancouver: UBC Press, 2014), 4-5.

${ }^{343}$ LAC, RG 24-C-3, Vol. 17257, File 1251, Folder 8. War Diary Summary of Events, November 1943; Cormier, Acadiens et la Seconde Guerre, 102-3.

${ }^{344}$ Mosby, Food Will Win the War, 135-6; "What About the Fishermen," The Halifax Chronicle, 31 March 1942 cited in Cormier, Acadiens et la Seconde Guerre, 21.

345 "Red Cross Society Reorganizes for Bilingualism," Le Madawaska, le 21 septembre 1939, 2.
} 
and pyjama committees were organized as well as a blood donor clinic where soldiers at the local training centre were among those who lined up to donate. ${ }^{346}$ Advertisements in all of the newspapers, and editorials, especially those by Lucien Fortin in Le Madawaska, encouraged citizens to donate generously to the Red Cross campaigns. These measures appear to have been effective. One article reported that even local schoolchildren had responded generously to the call by raising $\$ 58.30$ for soldiers at the front. ${ }^{347}$

Some communities created Civilian Volunteer Corps (CVC), whose members were trained to respond in case of sabotage or other war-related emergency. These civilian defence units and the Non-Permanent Active Militia provided men who were too old, unfit for overseas service, or unable to leave their civilian jobs with an opportunity to volunteer in a military or paramilitary capacity. After the entry of the United States into the war, New Brunswick was considered vulnerable to air raids and the CVC was retrained in an Air Raid Precaution role. ${ }^{348}$

In addition to donating their time to civil and patriotic organizations, the newspapers urged Acadians to do their part to hasten victory by controlling their consumption. Consumption of foodstuffs and gas was regulated through rationing and consumers were encouraged to limit other purchases to what was genuinely needed. Citizens were urged to save surplus paper, unused aluminum goods, and even old cooking grease, and donate them to their local Recovery Committee for repurposing into new paper and aircraft. ${ }^{349}$ Fats and oils contained glycerine which was used in the manufacture of explosives. One ad urging households to save grease reported that a

\footnotetext{
346 “'Blood Donor Clinic," Le Madawaska, le 8 octobre 1942, 2.

347 “L’epargne à l'école," Le Madawaska, le 3 avril 1941, 16.

348 "Second Step in Civilian Protection," Le Madawaska, le 1 janvier 1942, 2.

349 "Votre part pour hâter la victoire," Le Madawaska, le 4 septembre 1941, 3, 9.
} 
single pound of fat contained enough glycerine to produce the explosive necessary to manufacture 150 Bren gun rounds and two pounds supplied enough for ten anti-aircraft shells. ${ }^{350}$

One of the major ways that Acadians participated in the war effort was through financial contributions, including War Savings Stamps and Certificates and the purchase of Victory Bonds. Citizens were told that Canada's armies overseas desperately needed weapons and supplies in order to achieve victory over tyranny. Canada was asking its citizens to lend their money in an effort to hasten victory and to avoid the debt and massive inflation which had occurred in the last war. The purchase of bonds and certificates was touted as a way to invest in a better life in the post-war. Ads, including one which appeared in February 1942 proclaimed that "Ils [Germany and Japan] menacent le Canada à l'est et à l'ouest ... vos dollars vous sauveront, vos dollars vous reviendront." ${ }^{351}$ During the sixth loan campaign, Le Madawaska editor Fortin stated that saving to purchase bonds was a small sacrifice to make compared to that being made by Canadians serving overseas. He reminded readers of the importance of achieving victory over the Axis forces, "qui rêvent d'une domination mondiale et dont la Victoire signifierait pour nous un veritable esclavage économique, religieux et racial.” It was Acadians' duty to support materially and morally the Canadian troops overseas, "qui paient, eux, de leur vie le droit à la liberté." 352

For each of the Victory Bond campaigns, counties were assigned a minimum objective. During the second Victory Loan campaign, Madawaska county subscribed 214

\footnotetext{
350 “Les graisses sont des munitions," Le Madawaska, le 10 juin 1943, 11.

351 Annonce, "Vos dollars vous sauveront," Le Madawaska, le 5 février 1942, 11.

352 "Faisons le point," Le Madawaska, le 27 avril 1944, 3.
} 
percent of its objective. Le Madawaska stated that the county should be proud of its remarkable achievement, having been the only one in the entire country to have more than doubled its objective. This achievement is slightly deceiving, as most of the sums raised during the loan campaigns were not from ordinary citizens but rather large, often anglophone-owned, corporations, local credit unions, and, in Edmundston, the soldiers of No. 71 CA(B)TC. ${ }^{353}$ Most Acadians had not benefited from the higher salaries earned by workers in war industry and had more difficulty saving and contributing funds. However, La Voix d'Évangéline noted, ordinary Acadians contributed indirectly as it was their labour which contributed to the success of these corporations, and their small individual savings entrusted to the credit unions enabled these organizations to make their investments. ${ }^{354}$ In Le Madawaska, Fortin nonetheless continued to encourage his readers to save and invest as much as possible, stating that, in addition to supporting the war effort, these habits would benefit Acadians during the depression which he feared would follow the war. ${ }^{355}$

In addition to the patriotic appeals to support Canada and the Empire which were aimed at all Canadians, the opposition to Nazism in the ads and articles aimed at French

${ }^{353}$ LAC, RG 24-C-3, Vol. 17262, File 1252. War Diary Summary of Events, May 1944. Troops at No. 71 CA(B)TC made notable contributions to each of the Victory Loan drives and frequently led its group in the competition between training centres and army units in the province to see which could contribute the greatest share. During the $6^{\text {th }}$ Victory Loan, for example, the war diary reports the training centre achieved its minimum quota in a couple of days. By the end of the campaign, they had raised over 300 percent of their objective with each man, on average, having purchased $\$ 129$ worth of bonds.

354 “L'épargne acadienne," La Voix d'Évangéline, le 5 novembre 1942, 3. During Victory Loan campaigns, New Brunswick counties with large Acadian populations met and often exceeded their objectives. While corporations purchased large portions of the bonds, the contributions from ordinary citizens were also significant. In anglophone communities, however, the average citizen was often in a better financial position and more able to contribute. Later in the war, payment plans made it easier to purchase bonds but there is no data to indicate whether the Acadians made use of these plans.

355 "Pratiquons l'épargne et achetons des certificats," Le Madaawska, le 20 février 1941, 3. 
Canadians occasionally had religious connotations. ${ }^{356}$ Nazism was framed as an atheistic system which sought to destroy Christianity and the Catholic church, a centrepiece of Acadian identity, replacing it with a fanatical Hitler cult. ${ }^{357}$ One article discussed the Nazi use of euthanasia, sterilization, and the repression of the priests who spoke out against these measures to demonstrate the importance of stopping Hitler. The author insisted that the Nazis planned on imposing a new world order based on principles from livestock rearing manuals - selective breeding, and culling of the weak and sick. ${ }^{358}$ In a speech at the Canadian Club in Toronto, Quebec's Cardinal Villeneuve quoted Pope Pius XI, who saw that "in this vital conflict the fundamental problem of the world is at stake. For God or against God is the terrible alternative..." ${ }^{359}$ Printed statements from francophone Catholic leaders assured the faithful that stopping Hitler and his armies before they reached North America was essential. A German victory would have serious spiritual, social, and economic repercussions for Canada. ${ }^{360}$ Warnings about the seriousness of the Nazi threat undoubtedly played a role in encouraging participation and recruitment. J.E. Michaud declared that participating in the War Loan was an act of faith and a way to safeguard religious and civil liberties from the atheistic National Socialist regime that

\footnotetext{
${ }^{356}$ In his study of the Acadians in Nova Scotia during the Second World War, Ryan d'Eon found that the Nazi threat to Catholicism was a frequent, and important subject of discussion in Le Petit Courrier, a francophone newspaper in Nova Scotia. While the New Brunswick newspapers also discussed the Nazi threat to Catholicism, the subject appears to receive less attention than in Nova Scotia. See d'Eon, "Away but Still at Home," 39-45.

357 “L'Hitlerisme," Le Madawaska, le 31 juillet 1941, 3, 14.

358 "L'euthanazie [sic]," Le Madawaska, le 25 september 1941, 3, 6.

359 "La guerre, le Canada et le Canadien Français," La Voix d'Évangéline, le 24 avril 1941, 11. The Cardinal's speech was given and printed in English.

360 "Ce que nos prêtres pensent de la guerre," Le Madawaska, le 11 septembre 1941, 5, 13.
} 
was threatening to dominate the world. ${ }^{361}$ Some Acadians who volunteered for active service cited fear of a German victory as a motivating factor in their decision to enlist. ${ }^{362}$ Acadian participation was recognized by some anglophones, while others chose to see enlistment for overseas service as the ultimate way of judging a group's contributions. The latter concluded that Acadian participation, like that of other French Canadians, was insufficient. But Acadians believed they had made a significant contribution to the war effort whether as civilians or members of the military. In L'Évangéline 's victory supplement, columnist J.-B. Côté declared that the Acadians responded to the nation's call promptly, wholly, and without looking back. He believed that the Acadians were "probablement le plus bel exemple de clairvoyance et de loyauté à 1'Unité canadienne qui a été donné dans cette guerre."363 Participation was made all the more meaningful, he believed, because of the history of injustices suffered by the Acadians at the hands of the state.

\footnotetext{
361 "Souscrire est un acte de foi," Le Madawaska, le 5 juin 1941, 1.

362 Cormier, Acadiens et la Seconde Guerre, 78-79.

363 “Le patriotisme éclairé du peuple acadien," L'Évangéline, mai 1945, Supplément D.
} 


\section{Conclusion}

Conflict and disagreements between anglophones and francophones have occurred almost since the founding of settlements in what are now the Maritime provinces. Armed conflict between the opposing sides culminated in the expulsion of the Acadians in the eighteenth century. After their return, for Acadians in New Brunswick, conflict took the less outwardly visible forms of social, political, and economic discrimination. Acadians were forced to fight for access to quality education in their own language, representation in the church, and for well-paying jobs. For Acadians, these attempts to eliminate their presence in the Maritimes, and to assimilate those who returned, would not easily be forgotten and formed an integral part of their identity as a separate people and a community united by shared experience. This shared sense of identity and experience influenced the New Brunswick Acadian community's response to war and conscription and hardened their resolve to withstand pressures to conform to the opinion of the anglophone majority.

The Second World War was responsible for both uniting and dividing Canadians. For anglophone Canadians, historical and familial ties with Britain made Canadian nonparticipation unthinkable. Lacking the same level of emotional connection with either Britain or France, many francophones thought of themselves only as Canadians. They were more hesitant to become involved in another European war, especially given the divisions within Canadian society which had been caused by the imposition of conscription during the First World War. However, there was a general recognition that Hitler needed to be stopped; if this did not occur in Europe, then Canada would be under 
direct threat. Promises by Mackenzie King not to impose conscription allowed Canada to enter the war a united country.

As recruiting gradually started to decline in 1941 and the entry of Japan into the war expanded the need for home defence, calls for conscription began to surface. The decision to hold a plebiscite asking the public whether it was in favour of releasing the government from its previous pledges concerning methods of securing men for military service increased divisions between anglophones and francophones. French Canadians believed that the promise not to impose conscription for overseas service had been made specifically to them, and yet all Canadians were being given the opportunity to vote on taking back that promise. La Ligue pour la défense du Canada also believed that the plebiscite signaled the government's intention to impose conscription since people did not ask to be relieved of a promise unless they already intended to violate it. ${ }^{364}$ The government claimed that it did not intend to impose conscription immediately, but merely wanted moral authority to do so if such measures became necessary later in the war. No matter where they lived in Canada, French Canadians collectively voted against releasing the government from its pledge, while Canadians of British origin voted in the affirmative.

Histories of conscription typically ignore French Canadians outside of Quebec or consider them as synonymous with the Québécois. Acadians, like the Québécois, voted against conscription, but their views were a product of their own opinions, identity, and experiences. In Quebec, nationalist sentiment was predominant, with the result that the Québécois were more opposed to Canada's entry into the war than their Acadian

${ }^{364}$ Laurendeau, Crise de la conscription, 84. 
neighbours. Like many other Canadians, the Acadians were not happy to be going to war for the second time in a generation, but they believed that the causes of the war were just. As demonstrated by d'Eon and articles in Le Madawaska and L'Évangéline, the Acadians believed that Nazism posed a threat to Catholicism everywhere and not just in Europe. ${ }^{365}$ A linguistic and religious minority within their respective provinces and a linguistic minority within the Church, Acadians had fought hard for representation and understood what it was like to be oppressed. They considered it ironic that they were expected to go overseas and fight to free oppressed people when they still faced oppression at home.

Nugent states that Acadians reacted less strongly than Quebec to the plebiscite and conscription. ${ }^{366}$ While the plebiscite results demonstrate that the no vote was stronger in francophone Quebec than in francophone New Brunswick, it is important to recall how Acadians were being encouraged to vote. In Quebec, the campaign for a no vote was much more visible than in New Brunswick. Perhaps to avoid drawing the ire of the anglophone majority, calls to vote no were covert and few in number, even in the Frenchlanguage media. For example, while l'Ordre Jacques-Cartier did call on the population to vote no through its membership channels, information was mainly passed by word of mouth. Some pamphlets and radio programs from Quebec that urged a negative vote did make their way into the province. ${ }^{367}$ Local newspapers printed the opinions of both sides, although government sponsored ads, urging a yes vote, dominated the pages.

\footnotetext{
365 d'Eon, “Away but Still at Home," 40-45.; "L’Hitlerisme," Le Madawaska, le 31 juillet 1941, 3.

${ }^{366}$ Nugent, "The Acadian Response," 85.

${ }^{367}$ Centre d'études acadiennes Anselme-Chiasson, Fonds 30 Théophile-Godin, Chemise 30.2-3, Ordre de Jacques-Cartier circulaire ${ }^{\circ} 415$ du Secrétariat national à Ottawa, le 21 mars 1942; Centre d'études acadiennes Anselme-Chiasson, Fonds 1165 Ordre Jacques-Cartier - cellule François-Ciquart Edmundston. Procès-verbal, le 17 avril 1942; Doucet, "Politics," 258.
} 
Despite recognizing that their constituents were opposed to conscription in principle, Acadian politicians still urged them to vote yes. They believed that the plebiscite was about releasing the government from its pledge and that conscription would be implemented only if a dire need arose in the future. ${ }^{368}$ They feared a no vote could possibly bring down the government, whose Conservative replacement would be almost certain to impose conscription. ${ }^{369}$ Most Acadians ignored the counsel of their MPs and voted according to their conscience but, in the absence of a vocal campaign for a negative vote, it is likely that some Acadians believed their MPs when they said that the government had no intention to impose conscription and voted yes. Although the negative vote in Acadian ridings of New Brunswick was less than it was in Quebec, New Brunswick Acadians were still overwhelmingly opposed to the idea of conscripting men for overseas service. For them, however, this anti-conscriptionist sentiment was not at odds with their support for a voluntary war effort.

Acadians believed that voluntary enlistment would produce better soldiers and that it was more honourable to participate in the war effort voluntarily. ${ }^{370}$ Many volunteered for overseas service. While an official tally of the number of Acadians who served is unavailable, Cormier estimates that Acadians formed roughly 30 percent of New Brunswick enlistments, a figure proportionate to their share of the population. ${ }^{371}$ Morin-Pelletier suggests that some Acadians were reluctant to enlist. However, this was not necessarily because of an unwillingness to participate in the war effort but because

\footnotetext{
368 "Discours Veniot: La conscription une question de race," Le Madawaska, le 19 février 1942, 5, 11, 12, 15; "Les Acadiens du Nouveau-Brunswick ont fourni leur part de volontaires," La Voix d'Évangéline, le 5 mars 1942, 10.

369 "L'hon. Cardin demande à ses compatriots un vote affirmatif," Le Madawaska, le 16 avril 1942, 6, 11.

${ }^{370}$ Nugent, "The Acadian Response," 106-7.

${ }^{371}$ Cormier, Acadiens et la Seconde Guerre, 100.
} 
these men might have had responsibilities at home, were medically unfit, or feared discrimination within the military. Even in areas where enlistment was lower, levels of civilian participation, including voluntary and financial contributions, were quite high. While Anglophones gauged participation mostly in terms of enlistments, Acadians were more likely to consider military and civilian participation to be of equal importance. ${ }^{372}$ They prided themselves on their participation and support for the war effort and opposed any attempts by anglophones to accuse them of shirking their duty or to think of them as less dutiful, like the Québécois. Some Acadians noted the opposition to the war which existed in Quebec and reported that the same sentiment was not present in the Maritimes. $^{373}$

New Brunswick Acadians were less likely to be bilingual than their counterparts from Nova Scotia and Prince Edward Island, so it was more important to them that there were opportunities to train and serve in French. La Voix d'Évangéline acknowledged that it would be extremely difficult for Acadians to become good soldiers if they were trained in a language they did not understand. ${ }^{374}$ In addition to issues of access, the opportunity to train and serve in French likely played a major role in encouraging many young men from the northern New Brunswick to enlist in Quebec. Others preferred to serve in local New Brunswick units, even if that meant serving and completing at least part of their training in English; some even saw the army as an opportunity to improve their language skills. ${ }^{375}$ A lack of education and English language skills limited opportunities for many Acadians, who had few options outside the infantry. While many were seen as equals by

\footnotetext{
${ }^{372}$ Morin-Pelletier, "Récit de Guerre d'un Conscrit," 46-49.

${ }^{373}$ Nugent, "The Acadian Response," 100.

374 "Encore à propos do seul camp bilingue au N.B." La Voix d'Évangéline, le 17 octobre 1940, 3.

${ }^{375}$ Cormier, J'ai vécu la guerre, 88.
} 
their anglophone comrades, others faced prejudice and discrimination. Acadian participation despite these barriers serves further to dispel any remaining doubts about the willingness of New Brunswick Acadians to participate in the war effort.

Although it received little attention from Canadians more generally, the New Brunswick Acadian reaction to conscription is notable in that it reminded anglophone New Brunswickers that their province was composed of two distinct linguistic groups with separate perspectives and objectives. The history of Acadian resistance to efforts forcing them to comply with British or Anglo-Canadian policies dates to the seventeenth century and was not limited to conscription. In New Brunswick, Acadian expression of displeasure with the views of the majority was neither loud nor violent; rather it was consistent with their position as a minority in an anglophone majority province. While it was important to the Acadians to support causes that they believed in, they also sought to avoid provoking the wrath of the majority out of fear that this might result in a repeal of some of the few concessions which had been made. Their resistance to conscription took place in the context of a wider campaign for improved education and language rights as well as improved economic and political representation. That campaign had begun prior to the outbreak of war and would continue after its end. 
Bibliography

I. Primary Sources

A. Newspapers

L'Acadien (Moncton) 1917

L'Évangéline/La Voix d'Évangéline (Moncton, NB) 1917, 1939-1945

Le Madawaska (Edmundston, NB) 1939-1945

Daily Gleaner (Fredericton, NB) 1917, 1939-1945

B. Printed Sources

Centre d'études acadiennes Anselme-Chiasson (CEAAC), Fonds 30 Théophile-Godin, (document textuel), Chemise 30.2-3. "Ordre de Jacques-Cartier circulaire $n^{\circ} 415$ du Secrétariat national à Ottawa,” le 21 mars 1942.

Centre d'études acadiennes Anselme-Chiasson (CEAAC), Fonds 1165 Ordre JacquesCartier - cellule François-Ciquart Edmundston, (document textuel). "Procès-verbal," 1939-1945.

Harper, Burton. Interview by Mike Charrier. Canadian War Museum Oral History Project Interview Transcript, 26 September 2000.

House of Commons, Debates, 1939-1945.

Legislative Assembly of New Brunswick, Synoptic Report, 1942.

Library and Archives Canada (LAC), Department of National Defence fonds, (textual record), RG 24-C-3, Volume 17254-17258, File 1251. "War Diary No. 70 Canadian Army (Basic) Training Centre," August 1940-May 1945.

Library and Archives Canada (LAC), Department of National Defence fonds, (textual record), RG 24-C-3, Volume 17258-17263, File 1252. "War Diary No. 71 Canadian Army (Basic) Training Centre," October 1940-May 1945.

Library and Archives Canada (LAC). Diaries of William Lyon Mackenzie King. Select dates 1942, 1944.

Provincial Archives of New Brunswick (PANB), Records of the Office of Premier John B. McNair, Addresses 1942-1946, (textual record), RS 414 D5a1a. "Speech: Plebiscite Meeting at Woodstock," 19 April 1942. 
Statutes of Canada. National Resources Mobilization Act, Chapter 13, 1940.

II. Secondary Sources

A. Books

Allen, Ralph. Ordeal by Fire: Canada, 1910-1945. Toronto: Doubleday Canada, 1961.

Balzer, Timothy. The Information Front: The Canadian Army and News Management during the Second World War. Vancouver: UBC Press, 2011.

Blake, Raymond, Jeffrey Keshen, Norman Knowles, and Barbara Messamore. Conflict \& Compromise: Pre-Confederation Canada. Toronto: University of Toronto Press, 2017.

Brebner, John Bartlet. New England's Outpost: Acadia Before the Conquest of Canada. Hamden, CT: Archon, 1965.

Burns, E.L.M. Manpower in the Canadian Army 1939-1945. Toronto: Clarke, Irwin \& Co., 1956.

Byers, Daniel. Zombie Army: The Canadian Army and Conscription in the Second World War. Vancouver: UBC Press, 2016.

Cormier, Ronald. Les Acadiens et la Seconde Guerre mondiale. Moncton, NB: Éditions d'Acadie, 1996.

—_ Entre bombes et barbelés: Témoignages d'aviateurs et de prisonniers de guerre acadiens 1939-1945. Moncton, NB: Éditions d'Acadie, 1990.

__. "J'ai vécu la guerre”: Témoignages des soldats acadiens 1939-1945. Moncton, NB: Éditions d'Acadie, 1988.

Daigle, Jean. "Acadia, 1604-1763: An Historical Synthesis." In The Acadians of the Maritimes: Thematic Studies, 17-46. Moncton, NB: Centre d'études acadiennes, 1982.

Dawson, R. MacGregor. The Conscription Crisis of 1944. Toronto: University of Toronto Press, 1961.

Doucet, Philippe. "Politics and the Acadians." In The Acadians of the Maritimes: Thematic Studies, 219-69. Moncton, NB: Centre d'études acadiennes, 1982.

Granatstein, J.L. Canada's War: The Politics of the Mackenzie King Government, 19391945. Toronto: Oxford University Press, 1975. 
- Conscription in the Second World War 1939-1945: A Study in Political Management. Toronto: Ryerson Press, 1969.

- The Politics of Survival: The Conservative Party of Canada, 1939-1945. Toronto: University of Toronto Press, 1967.

Granatstein, J.L., and J.M. Hitsman. Broken Promises: A History of Conscription in Canada. Toronto: Oxford University Press, 1977.

Griffiths, Naomi E. S. The Acadians: Creation of a People. Toronto: McGraw-Hill Ryerson, 1973.

- The Contexts of Acadian History, 1686-1784. Montreal: McGill-Queen's University Press, 1992.

- From Migrant to Acadian: A North American Border People 1604-1755. Montreal: McGill-Queen's University Press, 2005.

Henry, Frances, and Carol Tator. Discourses of Domination: Racial Bias in the Canadian English-Language Press. Toronto: University of Toronto Press, 2002.

Hillmer, Norman. O.D. Skelton: A Portrait of Canadian Ambition. Toronto: University of Toronto Press, 2015.

Keshen, Jeffrey. Saints, Sinners, and Soldiers: Canada's Second World War. Vancouver: UBC Press, 2004.

Landry, Nicolas, et Nicole Lang. Histoire de l'Acadie. Sillery, QC: Septentrion, 2001.

Laurendeau, André. La crise de la conscription 1942. Montréal: Éditions du jour, 1962.

MacNutt, W.S. New Brunswick, a History: 1784-1867. Toronto: Macmillan, 1963.

Millman, Brock. Polarity, Patriotism, and Dissent in Great War Canada, 1914-1919. Toronto: University of Toronto Press, 2016.

Mosby, Ian. Food Will Win the War: The Politics, Culture, and Science of Food on Canada's Home Front. Vancouver: UBC Press, 2014.

Pariseau, Jean, and Serge Bernier. French Canadians and Bilingualism in the Canadian Armed Forces, Volume I, 1763-1969: The Fear of a Parallel Army. Ottawa: Department of National Defence, 1988.

Rees, Ronald. New Brunswick: An Illustrated History. Halifax, NS: Nimbus, 2014. 
Roy, Michel. L'Acadie des origines à nos jours: Essai de synthèse historique. Montreal: Éditions Québec/Amérique, 1981.

Sarty, Roger. The Maritime Defence of Canada. Toronto: Canadian Institute of Strategic Studies, 1996.

Savoie, Alexandre J. "Education in Acadia: 1604 to 1970." In The Acadians of the Maritimes: Thematic Studies, 383-427. Moncton, NB: Centre d'études acadiennes, 1982.

Savoie, Calixte F. Memoires d'un nationaliste acadien. Moncton, NB: Éditions d'Acadie, 1979.

Stacey, C.P. Arms, Men and Governments: The War Policies of Canada 1939-1945. Ottawa: Queen's Printer, 1970.

- Official History of the Canadian Army in the Second World War, Volume 1: Six Years of War the Army in Canada, Britain and the Pacific. Ottawa: Queen's Printer, 1955.

Stevenson, Michael D. Canada's Greatest Wartime Muddle: National Selective Service and the Mobilization of Human Resources during World War II. Montreal: McGill-Queen's University Press, 2001.

Tennyson, Brian, and Roger Sarty. Guardian of the Gulf: Sydney, Cape Breton, and the Atlantic Wars. Toronto: University of Toronto Press, 2000.

Theobald, Andrew. The Bitter Harvest of War: New Brunswick and the Conscription Crisis of 1917. Fredericton, NB: Goose Lane Editions, 2008.

Thériault, Léon. “Acadia, 1763-1978: An Historical Synthesis.” In The Acadians of the Maritimes: Thematic Studies, 47-86. Moncton, NB: Centre d'études acadiennes, 1982.

—. La question du pouvoir en Acadie: Essai. Deuxième édition. Moncton, NB: Éditions d'Acadie, 1982.

Tooley, Robert. Invicta: The Carleton and York Regiment in the Second World War. Fredericton, NB: New Ireland Press, 1989.

Wade, Mason. The French Canadians 1760-1967, Vol. 2: 1911-1967. Toronto: Macmillan, 1968.

Wilbur, Richard. The Rise of French New Brunswick. Halifax, NS: Formac, 1989.

B. Journals and Periodicals 
Buckner, Phillip. "Beware the Canadian Wolf: The Maritimes and Confederation." Acadiensis 46, no. 2 (2017): 177-95.

Massicotte, Julien, et Mélanie LeBlanc. "L'Acadie et la Seconde Guerre mondiale." Acadiensis 45, no. 2 (2016): 49-67.

Morin-Pelletier, Mélanie. “'J'ai combattu le bon combat, j’ai achevé ma course, j'ai gardé la foi': 1 Récit de guerre d'un conscrit néo-brunswickois, 1943-1945." Canadian Military History 22, no. 4 (2015): 45-58.

Richard, Chantal. "Acadian Collective Identity Before and After Confederation: The Case of New Brunswick Acadians.” Canadian Issues, Fall 2014: 24-28.

Sirois, Georges. "Centre d'instruction (élémentaire) No. 71 d'Edmundston, 1940-1945." Revue de la Société historique du Madawaska, juillet 1993: 4-73.

C. Theses

d'Eon, Ryan. "Away but Still at Home: A History of South Shore Nova Scotian Acadians During the Second World War." MA Thesis, University of New Brunswick, 2018.

Nugent, Helen Jean McClelland. "The Acadian Response to the Conscription Crisis of World War II.” PhD Dissertation, Michigan State University, 1983.

Thibodeau, Patricia. "The Re-Emergence of an Acadian Collective Identity as Highlighted by the Conscription Crisis of 1942." Undergraduate Thesis, Mount Allison University, 1997.

D. Websites

Office of the Commissioner of Official Languages for New Brunswick. "Official Languages in New Brunswick: Historical Benchmarks.” Accessed 2 August 2019, http://officiallanguages.nb.ca/publications-links-other/history-official-languages.

Parliament of Canada. “The Hon. Aurel D. Léger, Senator.” In Parliament of Canada Biography. Accessed May 10, 2019.https://lop.parl.ca/sites/ParlInfo/default/ en_CA/People/Profile?personId=14248.

—. "The Hon. Clarence Joseph Veniot, Senator." In Parliament of Canada Biography. Accessed May 10, 2019.https://lop.parl.ca/sites/ParlInfo/default/ en_CA/People/Profile?personId=7887.

—. "The Hon. Joseph Énoïl Michaud, P.C., M.P.” In Parliament of Canada Biography. Accessed May 10, 2019. https://lop.parl.ca/sites/ParlInfo/default/ en_CA/People/Profile?personId=15312. 